\title{
WestVirginiaUniversity
}

THE RESEARCH REPOSITORY @ WVU

Graduate Theses, Dissertations, and Problem Reports

2014

\section{Costume Design Process of Cabaret}

\author{
Candice Caldwell Day \\ West Virginia University
}

Follow this and additional works at: https://researchrepository.wvu.edu/etd

\section{Recommended Citation}

Day, Candice Caldwell, "Costume Design Process of Cabaret" (2014). Graduate Theses, Dissertations, and Problem Reports. 593.

https://researchrepository.wvu.edu/etd/593

This Thesis is protected by copyright and/or related rights. It has been brought to you by the The Research Repository @ WVU with permission from the rights-holder(s). You are free to use this Thesis in any way that is permitted by the copyright and related rights legislation that applies to your use. For other uses you must obtain permission from the rights-holder(s) directly, unless additional rights are indicated by a Creative Commons license in the record and/ or on the work itself. This Thesis has been accepted for inclusion in WVU Graduate Theses, Dissertations, and Problem Reports collection by an authorized administrator of The Research Repository @ WVU. For more information, please contact researchrepository@mail.wvu.edu. 


\title{
Costume Design Process of Cabaret
}

\author{
Candice Caldwell Day \\ Bachelor of Arts in Painting, Warren Wilson College, 2008
}

\author{
Thesis submitted to the \\ College of Creative Arts at West Virginia University \\ in partial fulfillment of the requirements for the degree of \\ Master of Fine Arts \\ in \\ Design and Technical Theatre: Costume Design and Technology
}

Committee Members:

Mary McClung, Associate Professor of Costume Design and Director of Costuming (Chair) Lee Blair, Assistant Professor of Acting and Undergraduate Acting Program Director Robert Klingelhoefer, Associate Professor of Scene Design, Technical Theatre Program Head Alan McEwen, Clinical Assistant Professor of Lighting and Sound Design

\author{
WVU School of Theatre and Dance \\ Morgantown, West Virginia \\ 2014
}

Keywords: Costume Design, Theater, Cabaret, Weimar Germany,

Kander and Ebb, Broadway Musical

(C) 2014 Candice Caldwell Day 


\section{ABSTRACT \\ Costume Design Process of Cabaret \\ Candice Caldwell Day}

This document is an account of my process as Costume Designer of West Virginia

University's School of Theatre and Dance's Fall 2013 production of Cabaret on the Lyell B. Clay Concert Theatre stage. This thesis details the design's development from initial script interpretation, directorial and designer meetings through research, process of execution, performance productions, and evaluative conclusions. The document is supported by research images, renderings, production photographs, and other organizational paperwork. 


\section{ACKNOWLEDGMENTS}

I would like to express my infinite gratitude to Shayne Day for his unwavering love and support throughout the thesis process, my Graduate career, and lifelong artistic journey.

Thanks to my Mother and extended family for their lifelong support.

I would also like to thank my Cabaret director and design team; Lee Blair, Jane Ryan, Tim Thistleton, Joe Dotts, and Savannah Yost, for making a colossal project enjoyable. The theatre faculty and staff of WVU for their expert guidance, especially Mary McClung, Sharon Goeres, Alan McEwen, Steven Neuenschwander, Robert Klingelhoefer, and the Costume Shop.

Thank you.

For W. David Caldwell and Marie "Bill" Goodnight 
CONTENTS

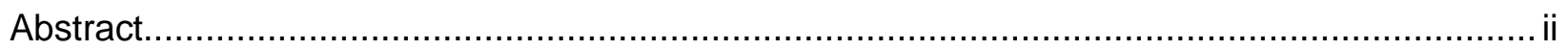

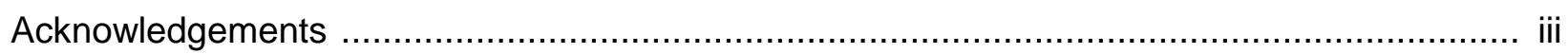

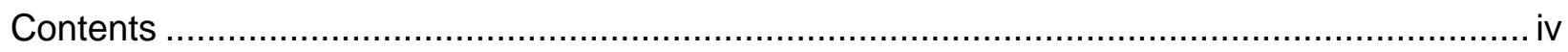

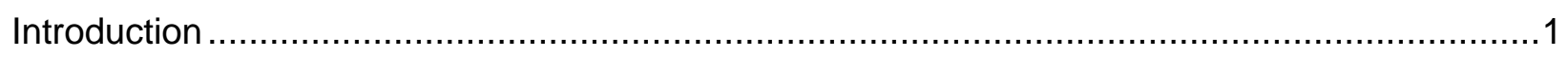

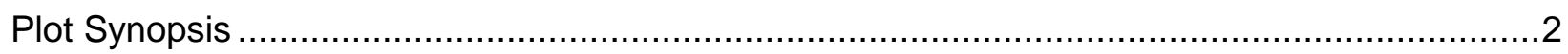

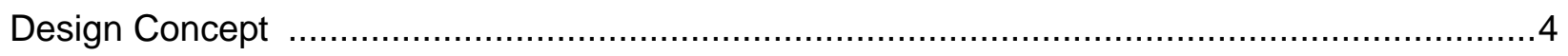

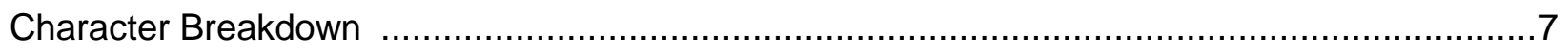

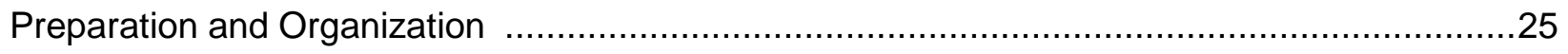

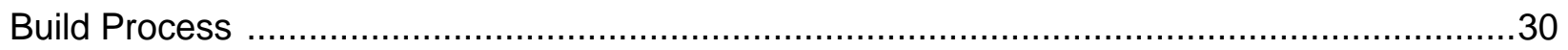

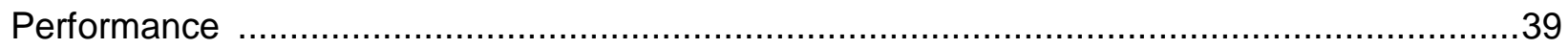

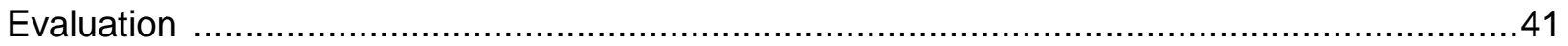

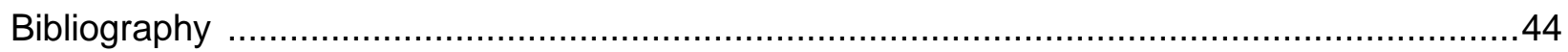

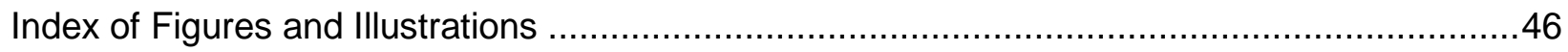

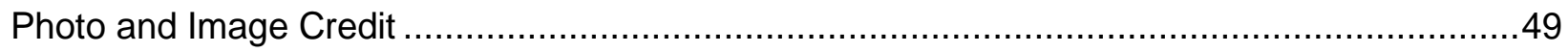

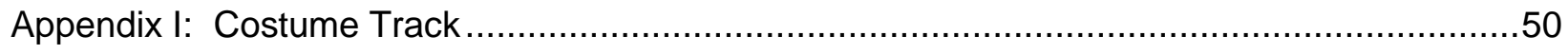

Appendix II: Costume Piece List Sample.......................................................................5

Appendix III: Director Lee Blair's Cast Matrix Spreadsheet ………….................................56

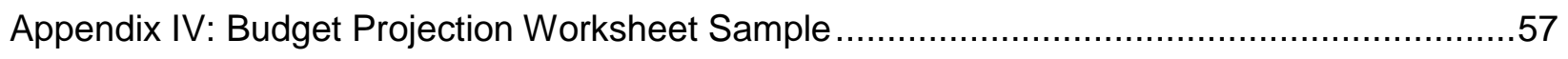

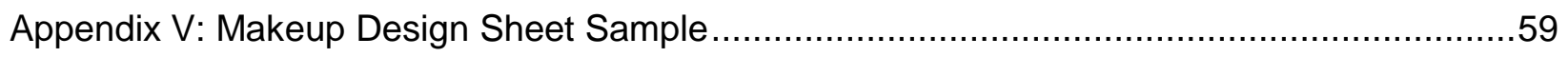

Appendix VI: Selected Costume Renderings and Production Photos ......................................60 


\section{INTRODUCTION}

During the Spring of 2013 I was given the rare opportunity of choosing my graduate costume design thesis project. Two forthcoming productions held immense challenge and opportunity for growth: a Neoclassical French comedy or a large scale Broadway musical. Deciding that my heart belonged to burlesque and Weimar Berlin, I chose the West Virginia University School of Theatre and Dance's production of Cabaret by Joe Masteroff, John Kander, and Fred Ebb.

The production was directed by Professor Lee Blair, musical direction by Professor Robert Thieme, choreography by Professor General Hambrick, and the design team consisted predominately of students. Scenic design was created by fellow graduate student Jane Ryan, lighting design by graduate student Tim Thistleton, sound design and engineering by Savannah Yost, and props design by Joseph Dotts. Professor Steven Neuenschwander served as technical director.

First design meetings occurred in April 2013, where we eagerly listened to the director's vision and concept of what our Cabaret production would embody. Taking away Director Blair's initial suggestions and historical background morsels, the designers prepared to steep themselves in Weimar Germany. This thesis is a reflection and evaluation of the design process from initial planning stages, through conceptual research and the build process, to live performance of the completed costume design. 


\section{PLOT SYNOPSIS}

The plot of Cabaret centers around Berlin's Kit Kat Klub in December 1929, a seedy subversive nightclub where persons from all walks of life may intermingle in the proverbial melting pot. It is a stage for humor and satire; a burlesque of sex, politics, life, and an underground escape from the ever-increasing conservative grip of the Nazi party. The mysterious club host, "The Emcee," opens the show with a sparkling, ostentatious musical introduction to this establishment: Wilkommen.

The "impudent muse," the "muse with the sharp tongue"-- this is the image of the cabaret that historians like to present. ...they romanticize it as a watering-place for the avant-garde, a wild crucible for modern ideas and experiments...

(Lareau 471-490)

Young American writer Clifford Bradshaw arrives in Berlin by railway car, eagerly embarking on a quest to find his muse. On his journey, he is introduced to Herr Ernst Ludwig, who introduces him to both the Kit Kat Klub and an apartment in Fraulein Schneider's boarding house. The scenes drift back and forth between Cliff's reality and dreamlike musical sequences in the nightclub. It is unclear (or perhaps up to the audience's artistic interpretation) whether these dreams are Cliff's hallucinations, burlesque numbers performed in the club, or the Emcee's personal commentary on Clifford's story.

The first evening he visits the nightclub, Cliff is mesmerized by the house starlet, brazen English run-away Sally Bowles. Singing the bawdy number, Don't Tell Mama, she is a modern flapper, the principal performer among the libidinous Kit Kat girls and boys, and the jealous proprietor Max's favorite girl. After stealing just one New Year's Eve kiss, Cliff is greeted the following day by Sally on his doorstep, accompanied by massive amounts of luggage. The young couple spark a whirlwind romance, echoed by a blossoming relationship between Frau Schneider and her tenant Herr Schultz, the local Jewish fruit shop owner. Schultz wins his lady love's heart with heartfelt gifts of rare and luxurious fruit (The Pineapple Song).

Comic relief is intermittently provided by tenant Fraulein Kost, a prostitute who services "Lonesome, patriotic, German boys" (sailors). The Emcee sings about unusual relationships and Weimar's various sexual appetites in Two Ladies. The vivacious and lascivious Berlin nightlife captivates Cliff and Sally, who play it loose and fancy-free until Sally discovers she is pregnant. Endeavoring to provide for his growing family, Clifford starts running paid errands to Paris for Ernst Ludwig. Audiences later learn that these are illegal funding trips for the rising Nazi party. The Emcee reflects on the desperate financial state of his peers, the depressed German Mark, and the peoples' cravings for wealthy tourists in the Money song. 
The more reserved and mature couple, Schneider and Schultz, become engaged on a whim to protect their chaste reputation from the inquisitive Fraulein Kost. Although their romance is secondary to Sally and Cliff's story, it is really the charming and heart-wrenching center of the tale. The elderly couple wins the audience's affection with their gentle awkwardness and sincerity. Sally insists on hosting an engagement party for her blissful friends at the fruit shop. This jovial occasion is shattered when Nazi Herr Ludwig learns that Schultz is a Jew. In a horrific act of betrayal and false attempt to brighten the mood, Fraulein Kost offers an inappropriate and haunting rendition of the Nazi propaganda anthem, Tomorrow Belongs to Me.

Act II opens with the Emcee in drag and Kit Kat Girls performing a surrealist burlesque kick-line of goose-stepping Nazi soldiers. Fraulein Schneider's tragic realization that her relationship is unsafe amid the rise of Nazi terror leads to the subsequent breaking of her engagement to Herr Schultz (Married). The Emcee accompanies this revelation with his tragiccomedic duet with a Gorilla, If You Could See Her Through My Eyes. Schneider sadly returns her engagement gift to Sally and Cliff, resolving that she will be safe from the Nazis if not married to a Jew (What Would You Do?). Sally begins to doubt her future as a successful mother, and yearns to return to the limelight at the "Klub." Cliff staunchly denies this request. He roughly commands Sally to pack her things, as he is taking her to the safety of his home in America, to raise their child away from the impending Nazi revolution. She refuses, thinking their life in Berlin wonderful and that politics are meaningless. In protest, she returns to perform at the club that night and her decision to stay is revealed in the famous song, Life is a Cabaret.

Early the next morning, Cliff is nursing wounds from a brawl with Ernst and his Nazi thugs. Sally reveals that she has bartered her treasured fur coat for an abortion, and receives a slap from Cliff in return. He hopes she will still escape with him, but instead she tearfully asks him to dedicate his book to her when it's finally completed. Cliff leaves, heartbroken and alone. We hear the first lines of his novel being penned as he exits on the train to Paris. The final scene is a return to the Klub and a reprise of Wilkommen, but now the performers are harsh, robotic automatons (sometimes dressed in concentration camp prisoner uniforms) and the Emcee is severe, sorrowful, and abrasive. This breakdown of the Kit Kat Klub is a metaphor for the downward spiral of Weimar Germany, and descent into the darkness of the Holocaust and World War II. 


\section{DESIGN CONCEPT}

Director Lee Blair led the first production design meeting by describing historical and storyline elements he considered to be important and verbally drawing inspirational imagery. He spoke of the period being Berlin's height as an avant-garde arts mecca, the decadence pushing the limits of the city as if on the edge of an active volcano. Director Blair recommended that the designers consult the Mel Gordon anthology, Voluptuous Panic: The Erotic World of Weimar Berlin, as an invaluable source and insight into the city's radical fringe culture. The economic level of the club was also very important, as the glamorous glitter and flash covered up the truth beneath the surface; that the party in Weimar Berlin was collapsing with every goosestepping boot strike.

Cabaret revivals are often synonymous with harsh industrial scenery and black-red-white color schemes. Our design team knew immediately that this was not suited for this production. Director Blair described the realistic daytime scenes in Fraulein Schneider's flat as being warm, safe, and inviting in soft, muted tones. The world of the club was to be a much darker underworld, its inhabitants brighter with strong colors that evoked a strange drug-induced euphoria. Convenient, as the patrons and performers would have likely been under the influence of one or many of the period's popular intoxicants. Alcohol, Absinthe, heroin, cocaine, morphine, and opium were the sustenance of evening revelers during this period (Ulrich). Following the standard of habitual drug addicts and prostitutes, the Kit Kat Girls and Boys were to be worn, poor, a little tired and rough around the edges, yet still aspiring to grandeur and glamour. These brassy broads and gents became the starlets of Cliff's fantasy world.

The scenic and costume designers were intrigued with the idea of keeping the world of the play in the 1920's decade, playing upon the vintage color and early art deco geometrics. Since the first few forays into the Klub are on New Year's Eve 1929, the fashion would have been steeped in the previous decade or only on the doorstep of the 1930's. To spark inspiration, scenic designer Jane Ryan and I poured over art books, photos of old Berlin nightclubs and period extant garments, and the paintings of German expressionists. These paintings became the source of desirable and useful color palettes for our team. German expressionist art is a natural resource for Cabaret, reflecting the land and culture of the setting in Berlin. Nighttime club scene color palettes were inspired by the work of artists Otto Dix, George Grosz, Max Beckmann, Marc Franz, and Wassily Kandinsky, that reflects a vibrant and gritty Germany (see Fig. 1). Although their work may first appear wildly colorful and playful, often there is a darker subterranean meaning: murder, prostitution, nefarious characters, and so forth. These allegories align perfectly with the themes in Cabaret. 

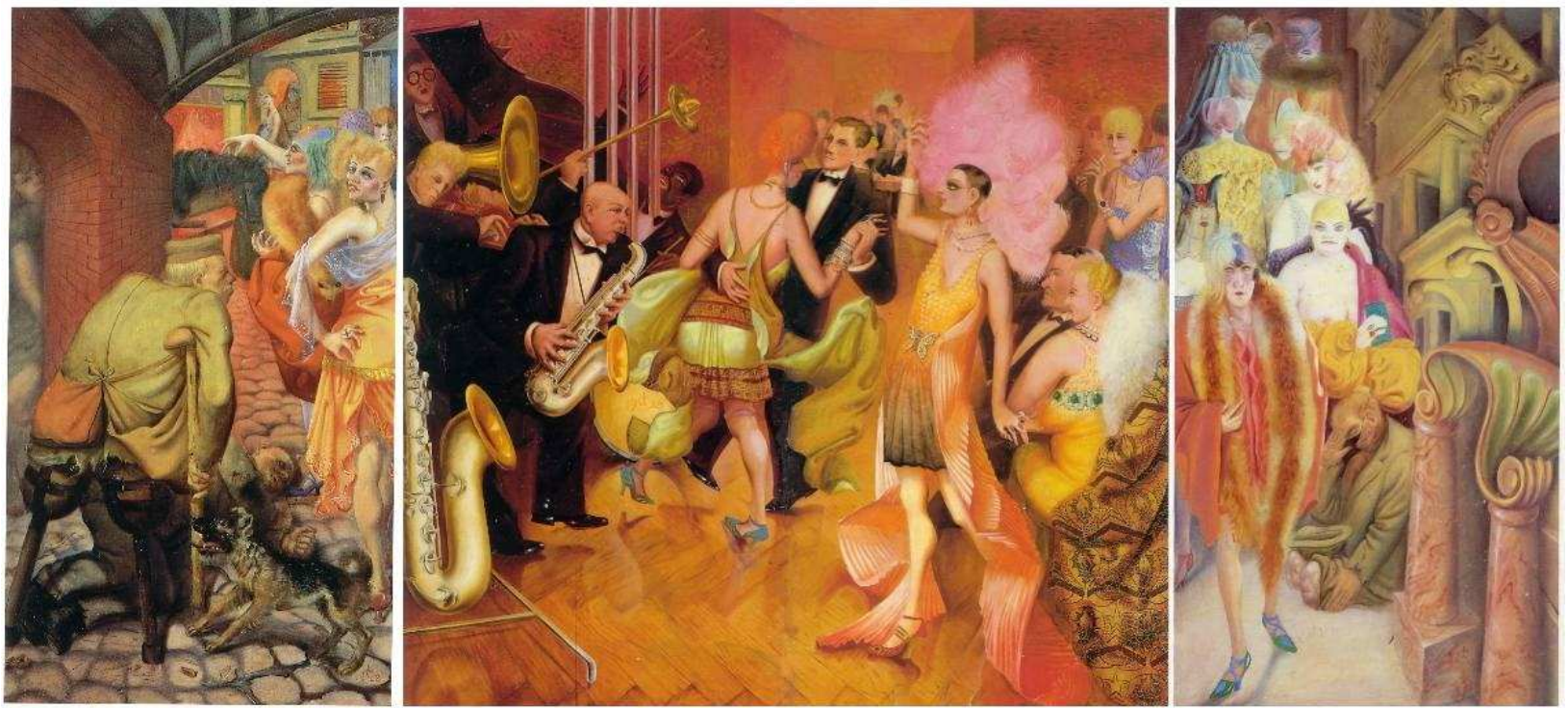

Fig 1: Otto Dix, Grosstadt (urban debauchery) Oil Painting.

The warmth of realism in Frau Schneider's boardinghouse was found in the paintings of expressionist Paul Klee and French art deco painter Edouard Benedictus (see Fig. 2). While utilizing the same tones that their contemporaries used to establish wild nighttime performances, these painters offer quieter, more muted palettes to choose from.

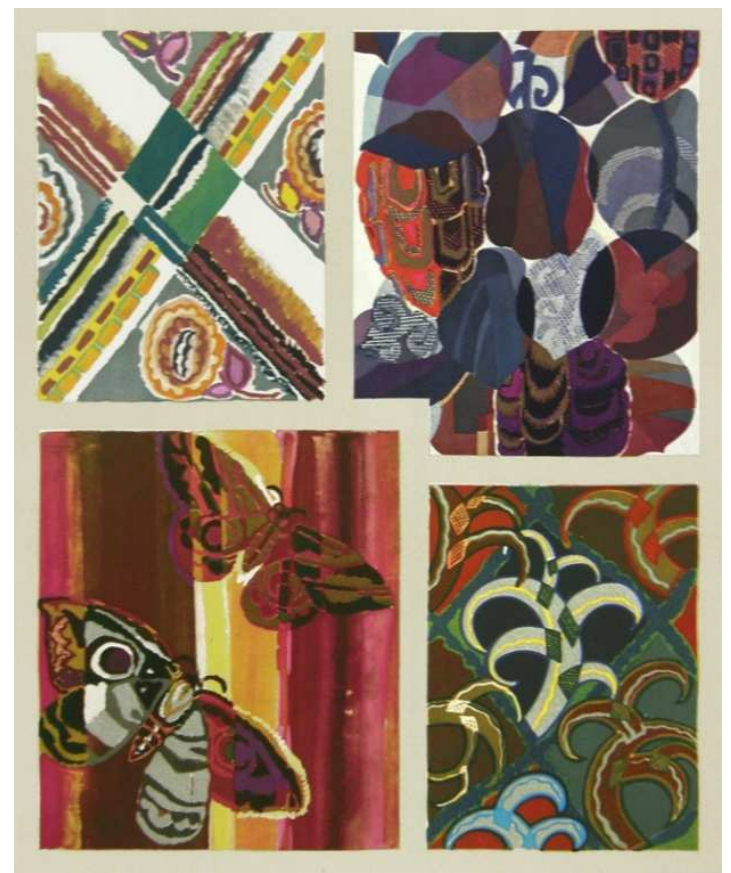

Fig. 2: Edouard Benedictus, Plate 11 from "Nouvelles Variations, "print 
Following the initial theme and color research, my next responsibility as costume designer was to the fashion of the period. I began a deep search into extant garments found in hundreds of images. My world became steeped in 1920's clothing, burlesque performers, Ziegfeld Follies, silent movie stars, vintage lingerie, Nazis, and music from the era provided by discs that accompanied an exceedingly useful book entitled Cabaret Berlin (Munz and Sieber). Thanks to the period's boom in photography and film, many images can be found in vintage fashion books and catalogs, online collections, and even internet fashion blogs. The arrival of such films as The Artist (2011) and The Great Gatsby (2013) were properly timed to allow a revival of the flapper style, and for research capitalization on the love affair with the twenties. Many museums catalog their extant garment collections online, which gave insight into actual clothing cut and colors, and assisted in gaining familiarity with options for styling (see Fig. 3-4).

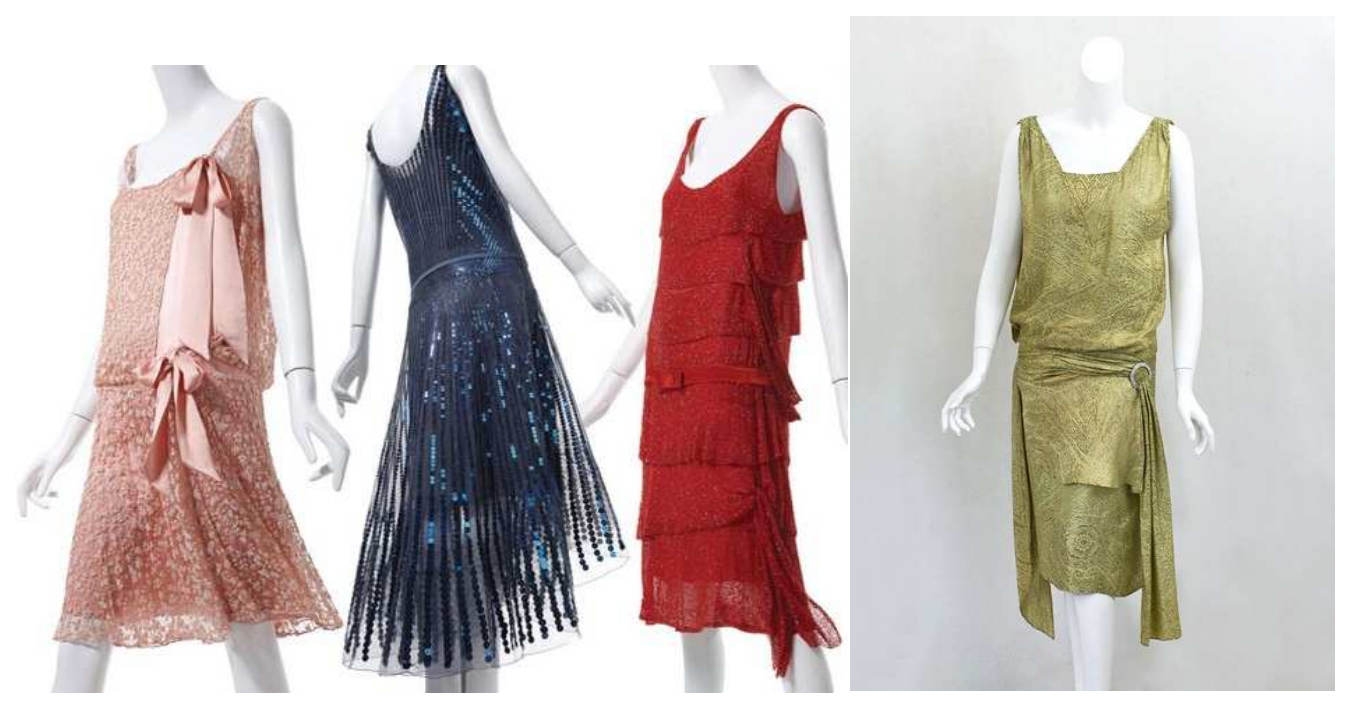

Fig 3: Gabrielle Chanel, Three gowns 1925-1928, Arizona Costume Institute Fig 4: Silk Party Dress 1925-1926, Vintage Textile Co.

The production venue also contained a new personal challenge: creating focus and appropriate scale with a sizable cast on a large proscenium stage in front of a 1,440 seat house. Cabaret has gained the reputation of being an interactive piece, finding its home in intimate venues where the lines between stage and audience are blurred. Cafe tables become house seating and performers might intertwine between patrons, treating them to a very personal experience-- almost as if they were truly in a vintage vaudeville hall of ill-repute in underground Berlin. This situation was entirely the opposite of that established norm: our spacious stage and house placed a much greater distance between the performers and their audience. Finding a way to make Cabaret's fabulous and iconic leading lady stand out became my first objective. 


\section{CHARACTER BREAKDOWN}

\section{SALLY BOWLES}

Unapologetic, sassy, and electric, British chanteuse Sally Bowles might be many things, but she can never be understated or boring. Liza Minnelli may have burned the image of a raven-haired maven into the global mind's eye in Bob Fosse's popular 1972 film version of Cabaret, but escaping her established look was a priority. Searching for inspiration among the era's great starlets, I searched photo archives for beauties such as Louise Brooks, Clara Bow, Faith Bacon, Marion Davies, Marlene Dietrich, Barbara LaMarr, Myrna Loy, and Betty Blythe. It became glaringly apparent that my ultimate choice for Sally would be the only wild vixen ever to break Berlin's heart: Anita Berber.

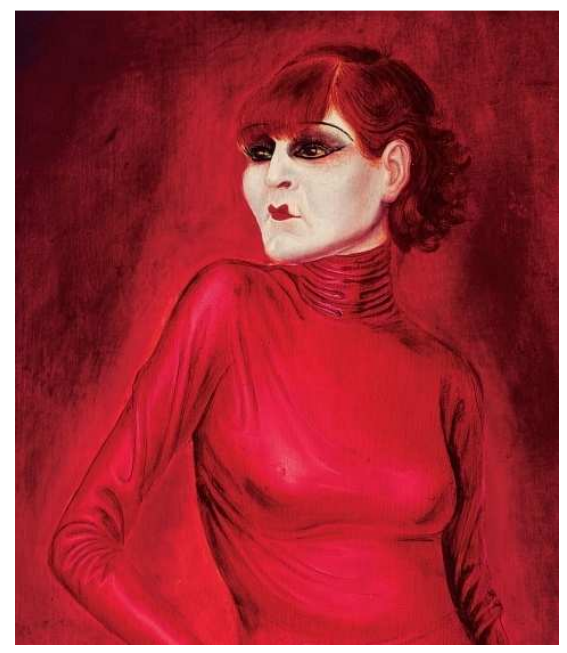

Fig 5: Otto Dix, Portrait of the Dancer Anita Berber, painting (section)

Infamous cabaret dancer, actress, and erotic performance artist, Berber made her way through Berlin in a heavily drug-induced fog, often with a pet monkey curled about her shoulders (Laikin Funkenstein 26-31). Her flaming red hair, sexually taboo performances, androgynous pansexual antics in gay and transvestite clubs, and frequent exhibitions of public nudity made her the hot ticket for tabloid fodder (Gordon). Knowing that her bobbed ruby and crimson hair would immediately attract and hold audience focus on an immense stage filled with other characters, this became the starting point for my vision of Sally Bowles (see Fig. 5).

The audience's first introduction to our gin and cocaine-soaked heroine is the sassy badgirl anthem, "Don't Tell Mama." Wanting Sally's debut to be as striking as her character inspiration, I chose a cobalt blue to compliment her scarlet locks and stand out against the warmth of her Kit Kat Girl backup dancers. Cool jewel tones became a theme for Sally's wardrobe, making her bold and offset to the many other faded colors onstage, and a constant 
reminder to Cliff of the underworld she existed in. In accordance with the low economic status of the Kit Kat performers, I wanted to avoid expensive looking beaded "flapper" dresses. However, in my mind, Sally was allowed a bit of glitz as the principal showgirl and club owner Max's "kept woman." The three photos below were major inspirations for this leotard-based performance costume piece (see Fig. 6-8):
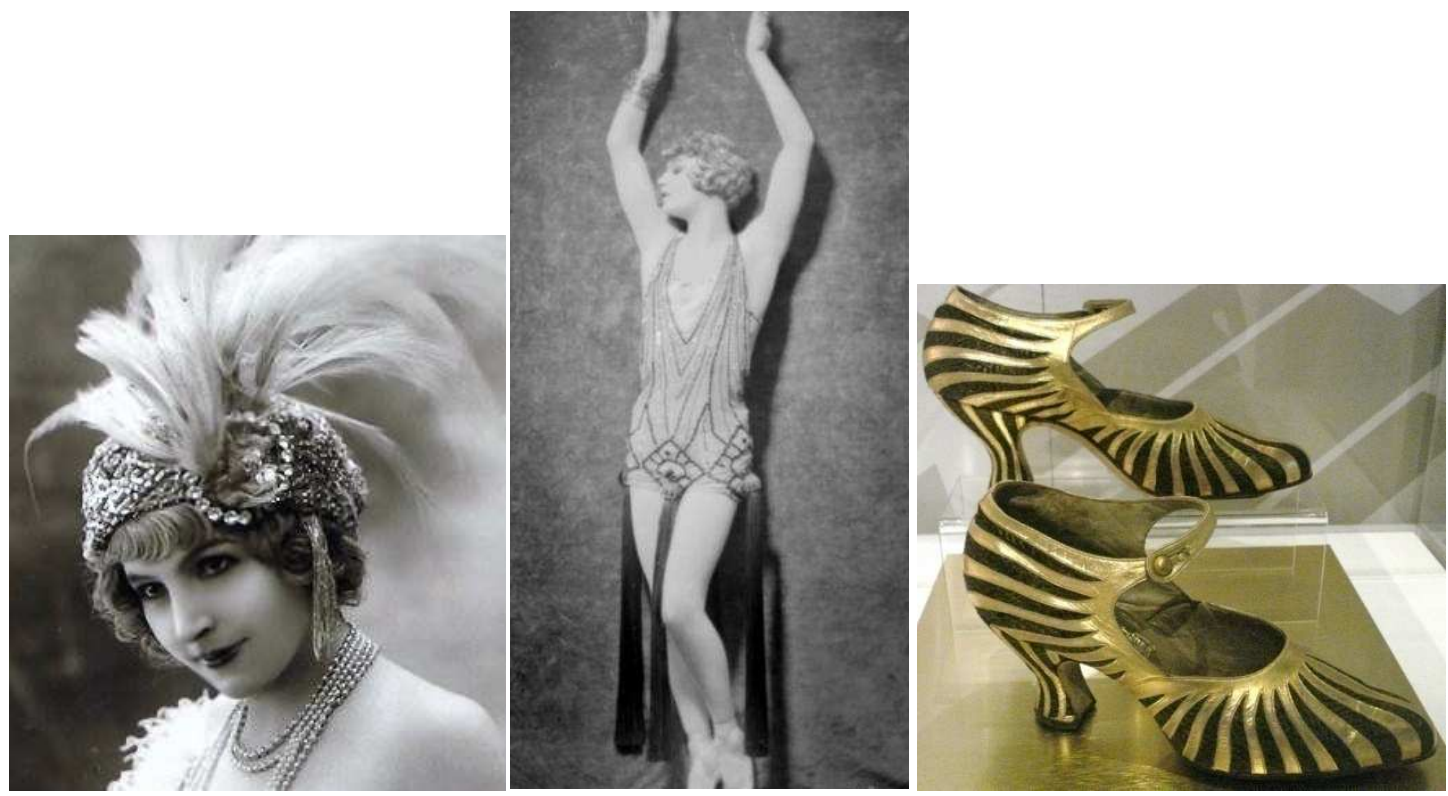

Fig. 6:Headdress, All That Jazz Vintage fashion blog

Fig. 7: Leotard Costume, All That Jazz Vintage fashion blog

Fig. 8: Starburst Shoe, 1922-1925, Bata Shoe Museum, Canada

In the script, one of Sally's most treasured possessions was her stylish and outlandish fur coat. Determined to do the iconic piece justice, a search through many images of extant wraps and illustrations of la mode furs ensued. Using my previous experience with these type of coats while working as an assistant costume draper and stitcher at Montana Shakespeare in the Parks theatre company (Summer 2012), I knew exactly what to hunt for and what the building challenges would be. The costume designer that summer, Alex Wren Meadows, had placed Hamlet in the 1920's era and Queen Gertrude had a penchant for these oversized and cuddly coats. One was so large that a "bum roll" was needed under the collar to obtain the desired wrap and height. The images featured below were main muses for Sally's cherished fur (see Fig 9-11): 

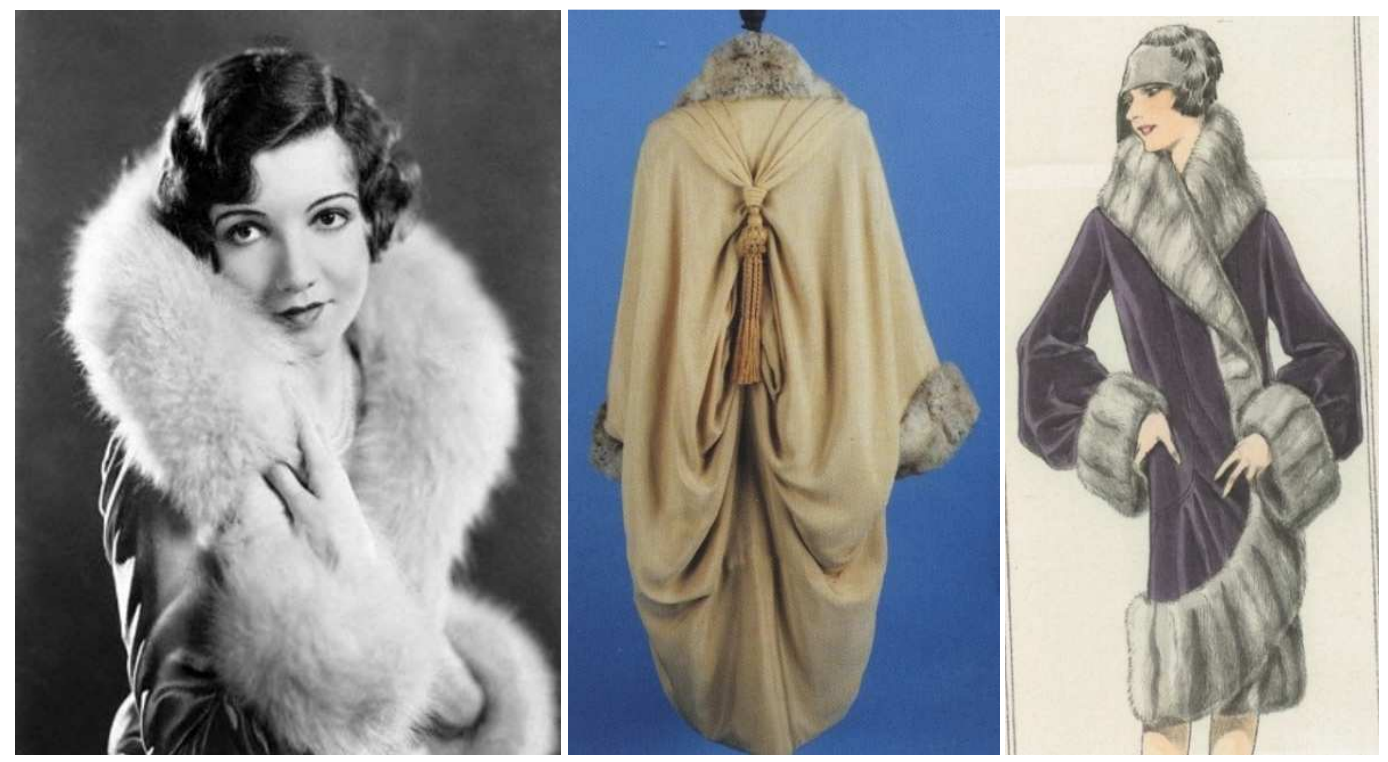

Fig 9: Claudette Colbert, actress

Fig 10: Silk Crepe Dolman, Gimbel Brothers, Paris, 1926

Fig 11: Velvet and fox fur promenade coat, Atelier Bachroitz, Paris 1927

Two other garments that our leading chanteuse required were a dressing gown and an evening cocktail party frock. The former was discovered in a book series that should be a necessity in any costume designer's library collection: Everyday Fashions (1920's) as Pictured in Sears and Other Catalogs (Blum). Hidden on the last few pages of this invaluable book, was a "morning leisure robe" that stole my breath due to its striking hand-painted artistry (see Fig. 12). After teaching myself to paint on Habotai silk in my second year of graduate school, I was eager to put this skill to use in recreating this exquisite robe.

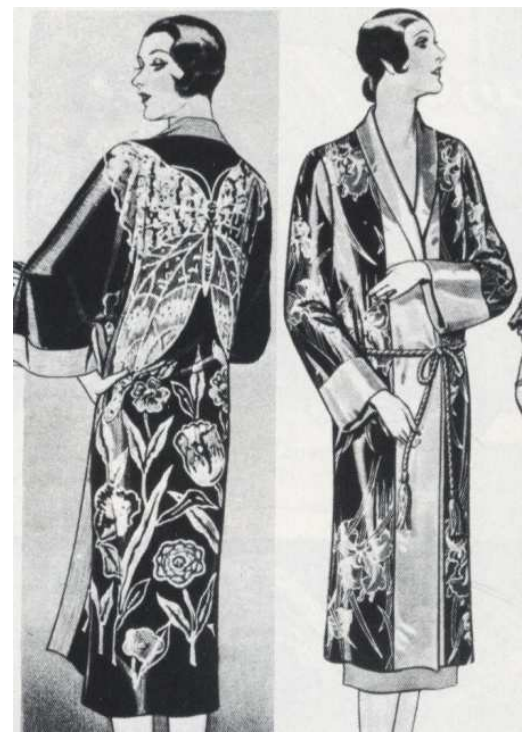

Fig 12: Morning Leisure Robe, Sears Catalog Archive, 1930 
Sally's dressing gown was invented as a solution to the script notation that is listed at the beginning of Act II, Scene four where the text states, "Sally is dressing to go out" (Masteroff, Ebb, and Kander). An image formed in my mind of starlets, dancers, and strippers alike donning silky robes to cover their costumes or lack thereof and relax backstage. The garment was ultimately used in multiple transitions by the Director. The Asian theme could be considered a nod to the "Orientalism" trend that crept its way into fashion after the turn of the century thanks to the popularity of Japanese prints and Pan-Asian inspired fashion designers such as Mariano Fortuny, Leon Bakst and Paul Poiret (Tortora and Eubank, Rothstein).

Following along the jewel-toned theme of Sally's wardrobe, the velvet cocktail frock for the fruit shop engagement party scene (Act I, Sc. 12) came from an amethyst hued and ruffled dress that appeared multiple times during my research phase (see Fig. 13-14). Deciding that the repeating image was a positive sign, the dress was chosen for the party scenario, and the $\mathrm{V}$-shape of the neckline later replicated itself as a recurring theme throughout the majority of Sally's attire.

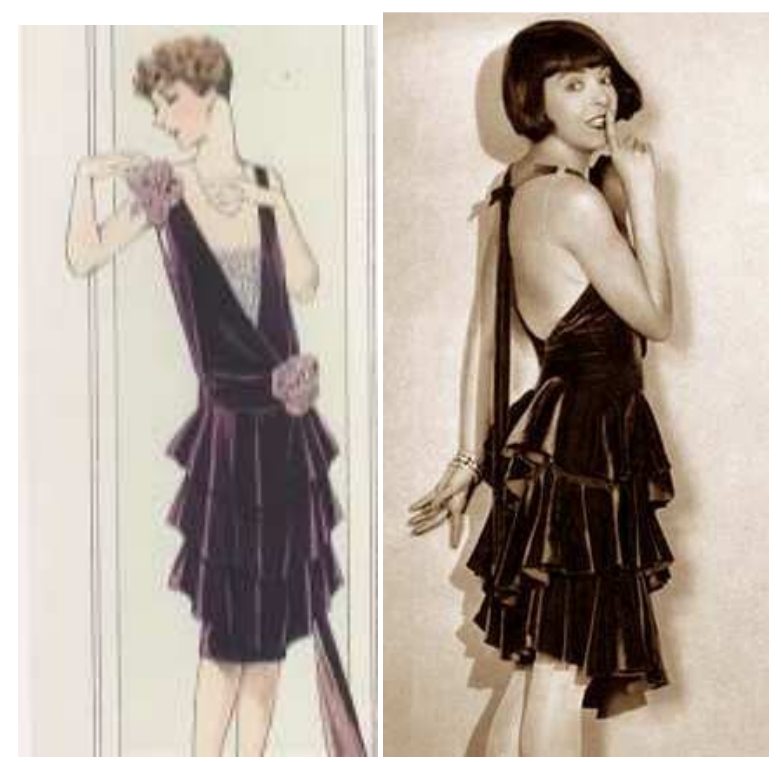

Fig 13: Velour dancing dress, Atelier Bachroitz, Paris, 1927

Fig 14: Colleen Moore, silent film actress and flapper, 1929

The final design challenge while inventing this ingénue found me struggling with the ultimate climatic moment and song of the musical, "Cabaret" (Act II, Scene 5). Sally is emotionally raw, vulnerable, and helpless at the beginning of her solo, but recovers to finish the song as a triumphant anthem and her reclamation of self and independence. She decides that she truly is a "Cabaret" queen and that she will not go to America with Cliff or bear his child. Instinctually, I initially focused on the "stripped bare" feeling that her position gave me. Drawing on some haunting portraits from my research, I envisioned a long sheer robe encrusted with 
shimmering beads and dark burnout velvet. I wanted her to be as physically naked as the character's moment made me feel. Bringing this concept to the director, I was met with disagreement. Professor Blair and I discussed that the core of the song should be about Sally's empowerment, and he had imagined that the club's owner (Max) had hurriedly shoved her into a long evening gown to perform that night. With greater understanding, I turned to a favorite influence that I was ecstatic to feature in this production: Erté (see Fig. 16). Since Romain de Tirtoff (Erté) was famous for fantastical designs featured not only in illustration but also on showgirls at the Ziegfeld Follies and Folies Bergére, the tribute felt appropriate. After searching through a few more designers to find the elegant length, train and shape I desired, Director Blair and I agreed upon some sketches and inspirational images that were suitably glamorous for the moment (see Fig. 15, 17).
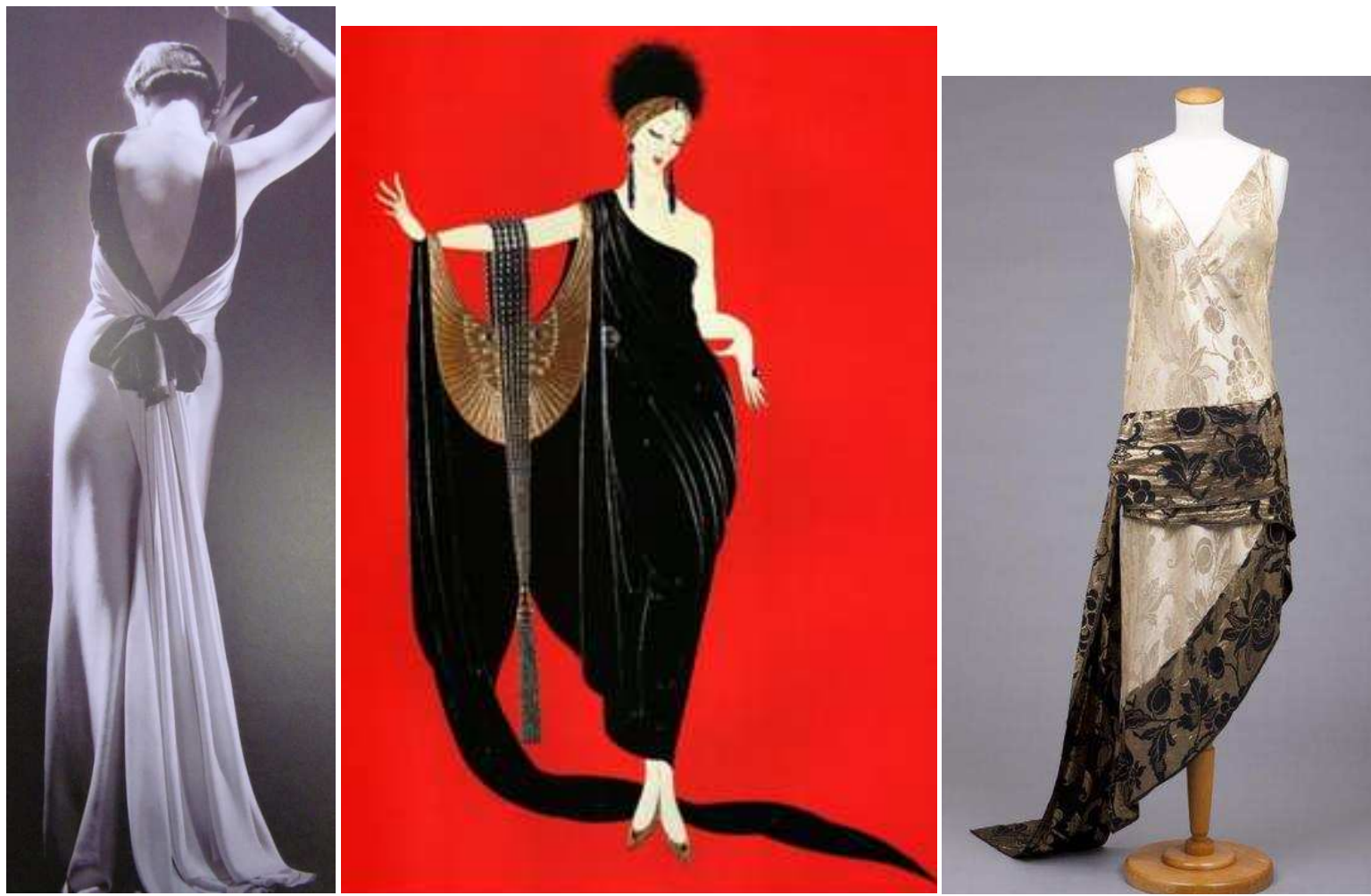

Fig. 15: Augusta Bernard Gown, Vogue Archives 1933

Fig 16: Erté, Illustration for Harper's Bazaar, May 1921

Fig 17: Callot Soeurs, Brocade Gown, 1928 


\section{THE EMCEE}

Anita Berber's marriage and artistic partnership with poet, actor, dancer and con-man Sebastian Droste made an easy pairing for selection as Sally and the Emcee (see Fig. 18). This iconic role is an androgynous blend of fluid sexuality, ringmaster showmanship, and lone wolf voyeur. Droste's long lines and lithe, lanky grace were pure inspiration. When preparing this highly recognizable character, it was one of the few times I felt that I needed to glance at images of what other designers had done. To put my own mark on the Emcee, I wanted to see the history of what had come before and how far into the realm of the transvestite I should push.

Sexualizing the traditional German lederhosen was an initial concept for the mysterious Cabaret narrator. After discussing his style and level of nudity with Professor Blair, I opted for a more sensuous underbust corset and knicker to show off the heeled boots that the script called for. Suspenders, painted spit curls, bowler hat, white collar and black tie rounded out the basic uniform in which the Emcee spends a majority of the show. Sketch comedy burlesque acts during nightclub scenes required the Emcee to have costumes and accessories to suit each musical performance. Such items included; a feather boa for "Two Ladies," a Hitler mustache for "Tomorrow Belongs to Me," and a top hat and tailcoat dripping with golden glitz for "Money." During Act 1 (Scene 4) the Kit Kat Klub host holds a New Year's midnight toast complete with burlesque quick-change from Father Time to Baby New Year. Director Blair's desire was for the Emcee to be as bawdy and raunchy as possible as the "naughty baby." Naturally a thong diaper, massive baby bonnet, and oversized phallic baby bottle came to mind, and became even more hedonistic after Mr. Blair suggested the bottle be a magnum of champagne. Our production was graced with a very talented performer, Vincent Pelligrino, who morphed naturally into my vision of Sebastian Droste's dark swagger, and I was very pleased with the resulting character.

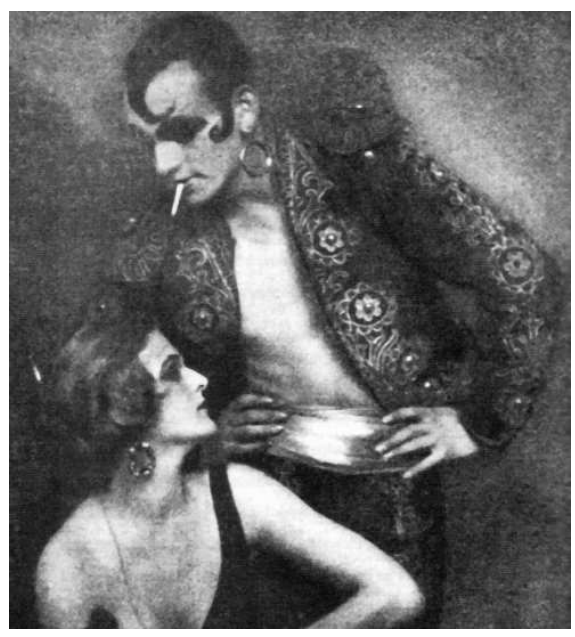

Fig 18: Sebastian Droste and Anita Berber, Morphine 


\section{CLIFFORD BRADSHAW}

Cabaret's other leading man represents the epitome of the all-American boy next door, come to Europe to be seduced, tantalized, scandalized, and have a fabulous time while trying to secure a muse for his novel. Being the salt of the earth in a world of illusion and glitter, Cliff's color scheme reflects the grounded earthyness of his disposition. Following the warm tones being used in the daytime scenes, he is connected to the realistic world, and is an outsider in the dark underworld of the Kit Kat Klub.

Cliff's wardrobe reflects his modest economic state. Originally deciding upon a 1920's plaid belted trench coat and brown suit from the Sears' catalog archive by Stella Blum, ultimately these patterns were switched when I went to pull from West Virginia University's costume stock. I actually found a perfect, worn-looking plaid blazer coat that shouted to me, "I belong to a warm and cozy writer!" Designers should never underestimate the thrilling surprises that lie in wait for them in costume storage basements. Adding to his heartwarming appeal, I allotted the story's hero interchangeable options while keeping the same basic suit concept. A suit vest or textured green sweater-vest allowed Cliff to look at home in Schneider's flat, but quickly change into his more formal suit when stepping out in society to the Kit Kat Klub. A hallmark of musical theatre, Cabaret has its own share of lightning-fast scene changes between the "real world" of Fraulein Schneider and the nightclub fantasy that its costume designer must consider during the planning stages.

\section{ERNST LUDWIG}

Every coin has two sides, and I wanted Ernst to reflect an opposite of Cliff's rugged boyish charm. The German Nazi slid into my imagination as a cold hard snake, shiny and glossy, waiting to strike. Although he is quite kind to Cliff, his hidden political agenda and unsympathetic nature toward Herr Schultz made him appear like a perfect fruit that is rotten inside. One might argue that he truly believes his cause is right, that he might be a sweet person if you really get to know him. But then again, Nazi war crimes during the Holocaust are still recognized as one of the single most atrocious genocides in history.

Highly polished in a slick navy pinstripe three piece suit, Ernst's icy blue tie should mirror his eyes. Combined with a Hamburg fedora and sleek platinum blonde hair, he is the picture of the perfect Nazi propaganda patriot. Hitler youth posters and men's fashion plates inspired the wardrobe for Ernst Ludwig (see Fig. 19-20). A snappy businessman with a bit of edge and never a hair out of place, this character was quick to take form in my mind's eye. 


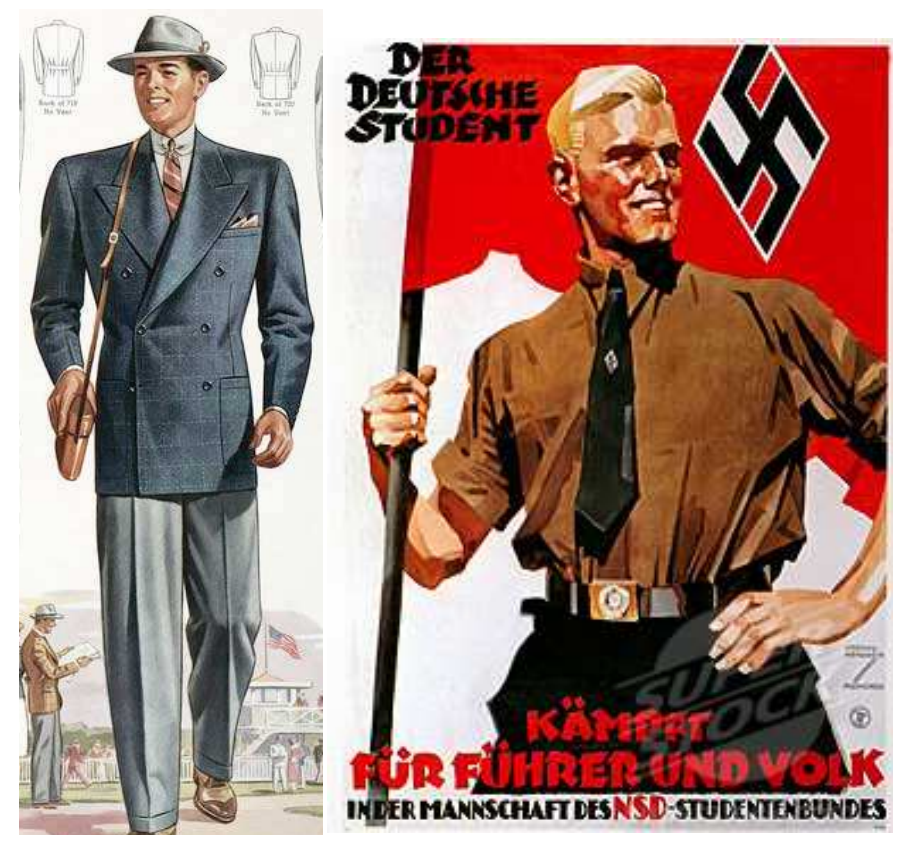

Fig 19: Early 1930's Men's Fashion Illustration

Fig 20: The German Student, Nazi Propaganda Poster

\section{FRAULEIN SCHNEIDER}

The boardinghouse matron is queen of her castle, but one of very humble means. I imagined Fraulein Schneider to be a bit sentimental for her past, clinging to what girlish charms and voluptuous curves she has left from the height of her youth, but not quite a beauty queen. The diminutive income she takes in from collected rents is likely only enough to feed her and keep the lights on in the aging building. In turn, she would not be out purchasing the latest Paris fashions, rather holding on to her daily staples and favorite pieces from her 30's and 40's.

These conclusions led me to pull most of my research from the Sears' Catalog Archive, since the middle class economic level of its patrons would have been closer to Schneider's. Keeping to the earlier part of the decade, I attempted to date her wardrobe in contrast to the younger ladies at the club. Being a conservative and simple woman, I also imagined decorum and femininity to be among her cherished values, and incorporated that idea into her warm and faded rose-toned color scheme. A quilted carnation pink house robe and cotton day dress are Schneider's preferred outfits for daily work around the boarding flat. The shape and style of these are directly from early 1920's fashion advertisements (see Fig. 21-22). 


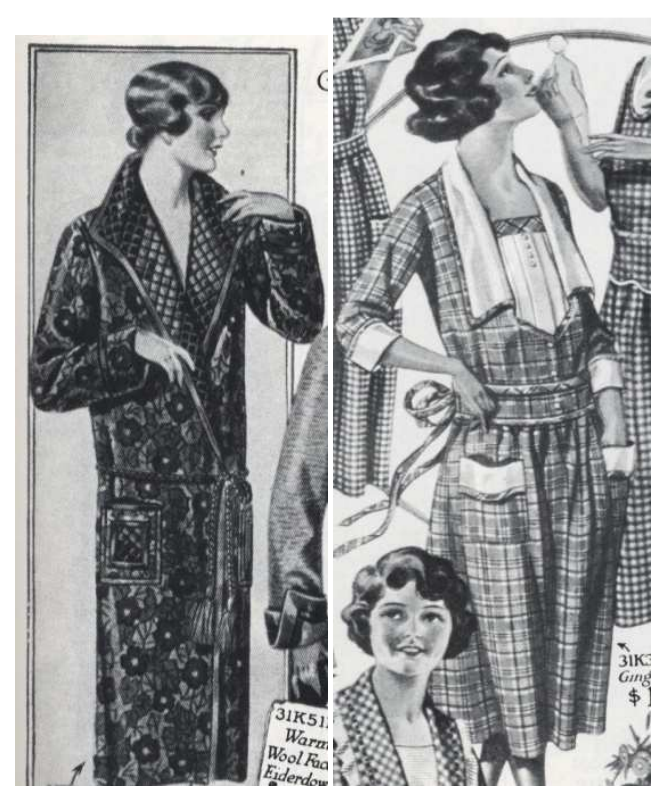

Fig 21: House Robe, Sears Catalog Archive

Fig 22: Morning Day Dress, Sears Catalog Archive

The fruit shop engagement party (Act One, Sc. 12) likely found Fraulein Schneider digging back into her wardrobe for a stunning frock (now vintage and dated) to impress her guests and look her best. Endeavoring to give her a hint of blushing bride glory, I imagined a cream brocade suiting that would be modest but flattering. To suggest the idea of the "dated" appearance of her suit yet maintain the image of the matronly, attractive older woman, I combined the silhouette of two attractive walking suits (see Fig. 23). The style would have been out of fashion by 1930, but as the guest of honor she would look feminine and fashionable.

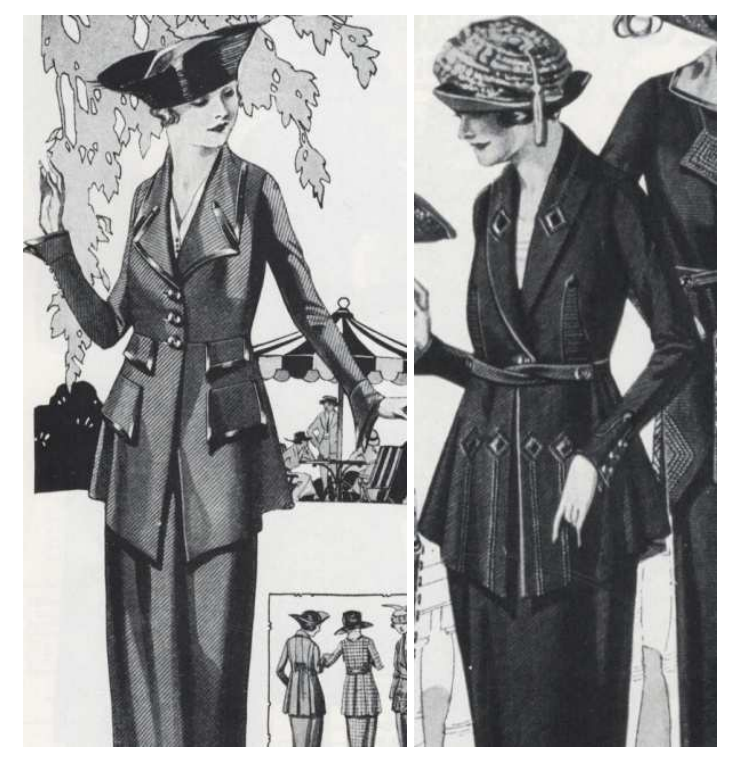

Fig 23: Two Early 1920's Walking Suits, Sears Catalog Archive 


\section{HERR SCHULTZ}

Just as their love blossomed from a warm friendship, my concept of Herr Schultz grew from my vision of Fraulein Schneider. Complimentary in contrast to his lady love (a sizeable and stout German woman), I wanted the fruit seller to be a diminutive and hunched sweet older gentleman. Although final casting did not coincide with my initial desires for this couple, I originally thought that playing with their statures might add another heartwarming and comedic element to their love story.

Searching through vintage era photographs led to an image of my ideal Herr Schultz; a tender looking soul with round glasses, a moustache, and a half-balding pate (see Fig. 24). His warm gray coloring is representative of his faded age and vigor, and meant to harmonize with the warm rose and burgundy tones of his fiancé. A funny clashing bowtie and mismatched pants were the manor of dealing with the script's suggestion that Schultz dresses a bit off color, not seeming to have much fashion sense.

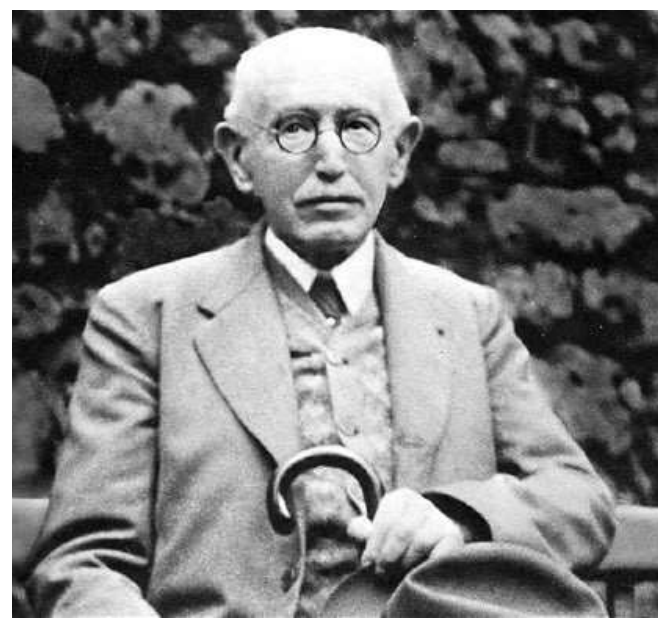

Fig. 24: Captain Alfred Dreyfus, Inspiration photograph

\section{FRAULEIN KOST}

Early in the design process, I was given a warning by my lighting designer, Tim Thisleton, to be cautious and specific with my use of the color red. He shared a story of audience assumptions that this was a symbolic Nazi color, and anything that was red might hold that negative association. The anecdote compelled me to reserve the crimson shade only for Nazi uniforms, armbands, and political supporters. Fraulein Kost's display of Nazi patriotism during the engagement party (Act I, Sc. 12) influenced the decision to make ruby red the signature hue throughout her wardrobe. Kost, Cabaret's queen of the Red Light District, claims 
to be doing her duty to her beloved Germany by supporting its sailors and soldiers, inadvertently turning Schneider's boardinghouse into her own private brothel.

Images of Marlene Dietrich paved the way for Kost's permanently post-coital appearance (see Fig. 25). Vintage lingerie and stockings are her career uniform, but Director Blair quite correctly suggested that she have a robe, as a thin veil of illusory modesty. In the many scenes where Kost's landlady catches her in the act of escorting sailors out of the bedroom, being able to hide her scantily clad figure allows her a modicum of dignity. I chose a style of robe that was just as flirtatious as the vixen within it. Flowing chiffon engageantes and a fluffy marabou collar personalized the cherry blossom embroidered negligee (see Fig. 26).
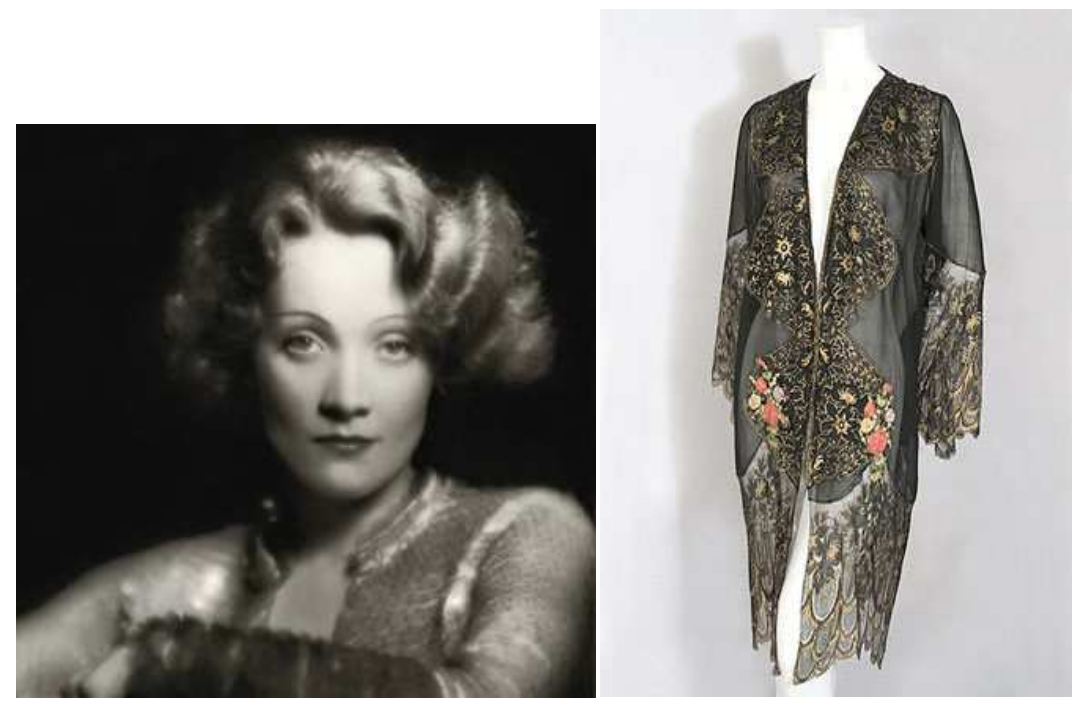

Fig 25: Actress Marlene Dietrich, Hairstyle inspiration

Fig 26: Sheer Silk Negligee, 1927-1930, Vintage Textile

Fraulein Kost's Nazi tribute that she dedicates to Ernst during the engagement party called for a frock as shocking as her behavior. I wanted all audience and cast eyes to be locked on her during the solo so naturally I continued with my theme of scarlet. Imagining the harlot to be the most raucous, trashy guest at the celebration, I combined multiple cocktail dresses into one skimpy and flashy number. The ensemble resembled the popular Halloween costume fringe and beaded "flapper" dresses that I tried desperately to avoid in my design. By utilizing textured sheer and eyelash fabrics, the skirt had many small circular flounces that wiggled, fluttered, and undulated in a wild and seductive manner. This created the appearance of a flapper dress without having to purchase or rent an expensive vintage reproduction gown. 


\section{KIT KAT GIRLS}

Professor Blair had posed Klub performer descriptions as grungy but glamorous, overthe-top yet cheesy and homemade. This concept was a fantastic guide for designing the nightclub costumes, however originally a bit confusing and frustrating to decode. With this tip came the realization that most of the Kit Kat chorus were likely of low income, performing and prostituting to support drug habits and drunken party lifestyles. Our team also determined that the struggling, underground nightclub would not contribute much toward costuming a massive chorus line of identical ladies, therefore the performers would wear a base lingerie costume and resort to constructing their own accessories and pieces for specific numbers.

Researching vintage lingerie found me feeling a bit cornered. It became clear that I had to broaden my time window to extend further into the 1930's to make the silhouette as sultry and feminine as I desired. I found that the silhouette of many bras and corsets of the twenties were flattening, not flattering. Items that became desirable for the design included; silky bras and flared lace tap panties, girdles, corselets, teddies, and slips (see Fig. 27-29). Just a peek at vintage undergarment boutiques told me that I would not be buying many of these expensive pieces directly. I would have to thrift, chop and alter lingerie to make six or seven chorus girls work within my budget. Since these ladies were also the main dance core of the production, reinforcement and garment support with high movement potential was also a concern. Each character had her own name and personality in some revival versions of the script so Professor Blair and I concluded that each girl's lingerie needed to be unique. He was also interested in casting different body types and sizes so I wanted to make allowances between two-piece lingerie sets and one piece items so that an actress of any size would feel sexy and comfortable on stage in her underwear.

The color scheme for this collection was taken from the warm glowing tones present in Otto Dix's Grosstadt painting (see Fig. 1), attempting to draw focus to the girls among the club's majority of dark colored, suited male patrons. The light or pale tones accented with black lace played well with Sally Bowles' cobalt blue dance costume and was reminiscent of Parisian and European styled lingerie. Notable sources for the Kit Kat Girls' main costumes included:

Fashions of the Roaring 1920's by Ellie Laubner, Vintage Lingerie by Jill Salen, The Metropolitan Museum of Art Costume Institute, the 1920's Sears Catalog Archive (Stella Blum), photos of 1920's starlets in underpinnings, Etsy vintage resellers, and Dollhouse Bettie online boutique. 

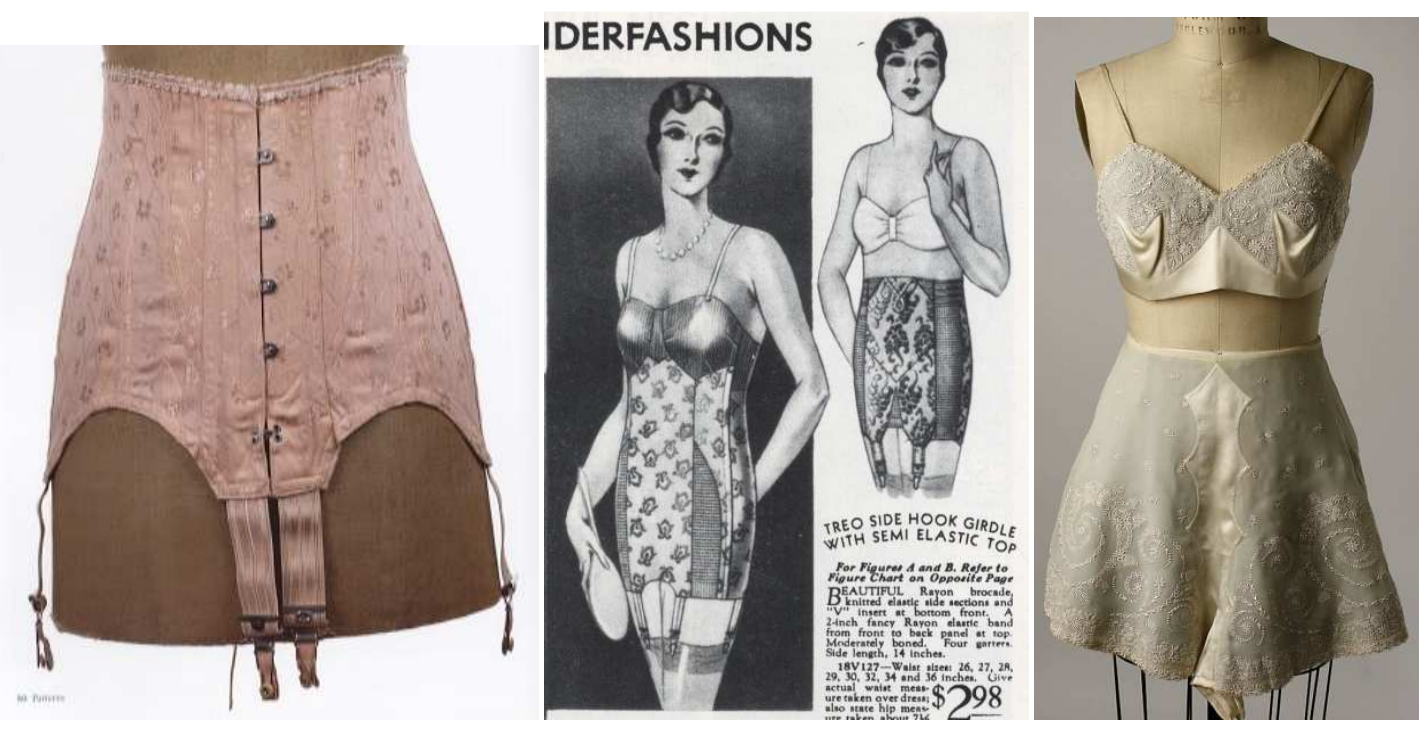

Fig. 27: Girdle, 1932. Vintage Lingerie

Fig. 28: Foundation undergarments, 1930-1931. Sears Catalog Archive.

Fig. 29: Silk Bra and Tap Panty Set. 1930. The Met Costume Institute.

Makeup and hair design derived from period images of black and white beauties, antique style sheets from advertisements and ladies' journals, and some modern artistic inspiration from runway and fashion editorials. The chorus girls' hair needed to contrast with Sally Bowles' smooth scarlet bob while not detracting from her attention-grabbing, center stage style. I chose brunette shades and German Aryan blondes, with all six ladies sporting variations on the fingerwave hairstyle (see Fig. 30). Silent film stars ushered in the era of celebrity worship and fashion imitation, including the wider use of cosmetics. The flapper panache included heavy eye makeup, pencil thin eyebrows, and darkly painted bee-stung lips (Rennells). Sally Bowles, the Kit Kat Girls, and Fraulein Kost are based on an artistic interpretation of this period makeup (see Fig. 31, 32). The Emcee and Kit Kat Boys also wore a slightly altered form of this makeup style.
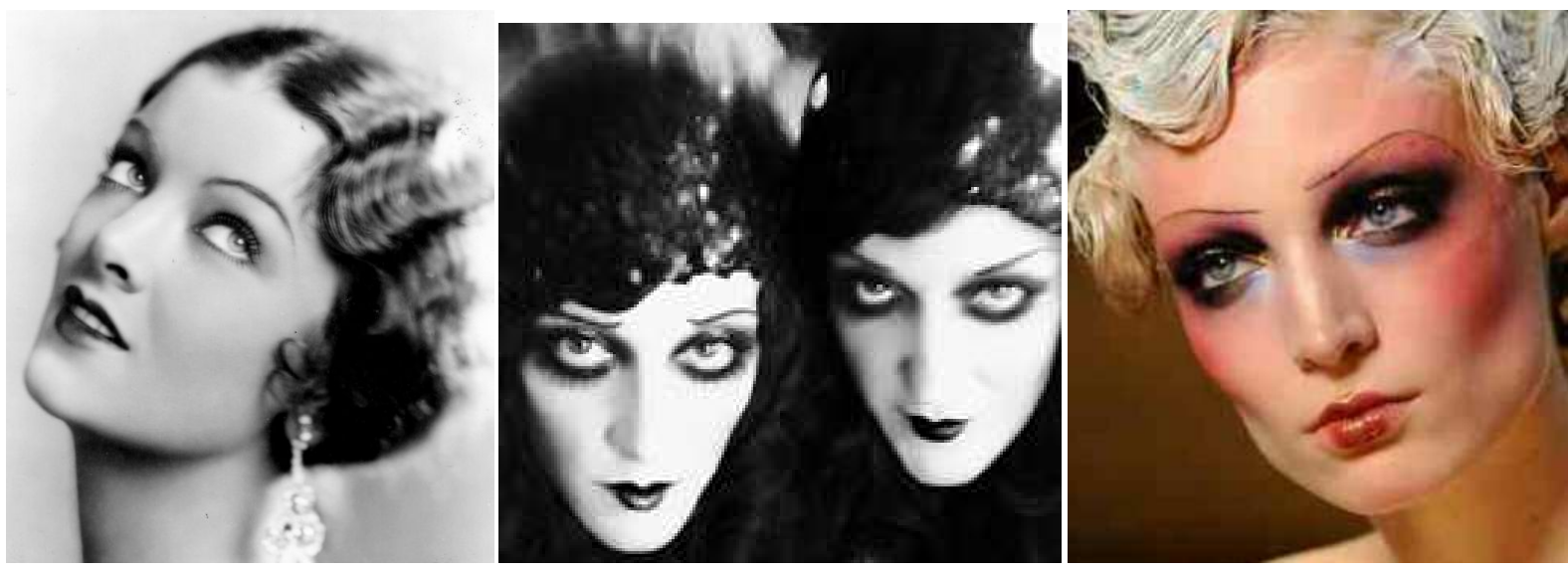

Fig 30: Actress Myrna Loy, Finger-wave Hairstyle

Fig 31, 32: Flapper Makeup inspirations 
The Kit Kat Girls' first varied appearance is welcomed in the tongue and cheek number, "Two Ladies." Typically this burlesque of alternative relationships is heralded by the Emcee and two folkloric German milkmaids. Following my director's advice to keep this song playful and very humorous, I chose two sheer pink babydoll dresses, adorned with frilly feather boas on the bust and hemline. Topped with gold lamé turbans, I imagined these to be the flirtatious and ludicrous outfits that trio would slip on for teasing and chasing. Initially I had fallen in love with the concept of having the threesome tantalize the audience from behind giant, pink ostrich feather fans, but the idea was later cut due to lack of budget. The famous performer, Sally Rand, popularized these fabulous fans in 1930's burlesque.

The "Money" song (Act 1, Scene 10) acknowledges the depression the German mark was having during the period. Tourism revenues and stronger foreign currencies were desirable but the one thing universally lusted after was gold. Visualizing the chorus and Emcee dripping with golden coins, I found a shimmering muse in the bohemian, exotica, belly-dance trend from the silent film era (see Fig. 34). There are numerous photos of Anita Berber, Kim Novak, Josephine Baker, Ziegfeld Follies girls, and Betty Blythe in the Queen of Sheba (1921) wearing metallic bust plates and beaded adornments (see Fig. 33). These golden crowns and arm decorations were treated as accessories and layered on top of the chorus' main lingerie outfits.
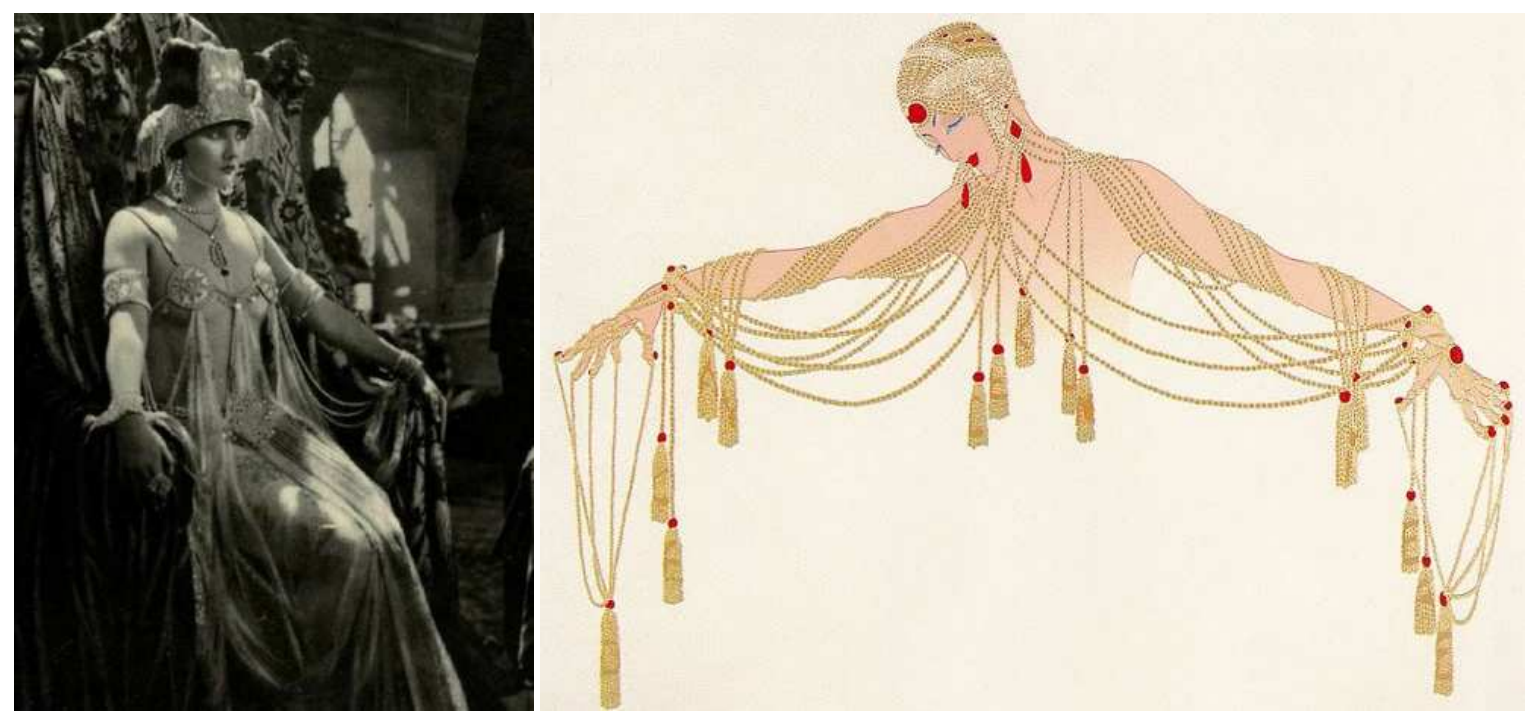

Fig 33: Betty Blythe in Queen of Sheba. 1921.

Fig 34: Illustration for Harper's Bazaar, Erté. 1918. 
Sally Bowles invites all her friends to the engagement party for Fraulein Schneider and Herr Schultz in Act 1, Scene 12. This includes the majority of her colleagues from the Kit Kat Klub, who I envisioned wearing the best cocktail frocks afforded by their income. These dresses would not cross the boundary into high-end chiffon and beaded fringe gowns. It was determined early in the design process that borrowing these six dresses was the best way to proceed. I was making a conscious effort to conserve precious time and budget. However, this was the first time I ever sought to rent or borrow a huge section of costumes for a production. This left me rather nervous, not knowing what I would encounter or what my options would be when I began searching in earnest. I conjured a combination of styles based on a basic 1920's sheath dress, all in attractive but muted tones from the period's color palettes. They needed to be stylish, but not distract from Sally's or Fraulein Kost's conspicuous frock colors (purple and red, respectively). This simple form could be easily draped with other fabrics to add interest and unique details for each garment, and accessorized with fur stoles, wraps, necklaces, cloche hats and period headwear. To obtain the dresses, Professor McClung assisted me in reaching out to colleagues at Fairmont State University and University of Mississippi.

The Nazi kick line that opens Act II after intermission is a jarring and shocking start to the downward spiral of the storyline. Given the open directive of "very scantily clad," I sought to create a sexy burlesque of the Nazi military regalia. Beginning with a photograph of burlesque dancer Faith Bacon (see Fig. 35), the traditional Nazi uniform was pared down until it was a cropped jacket, officer's hat, jackboots, long gloves, and precision placed faux leather strapping and thong.

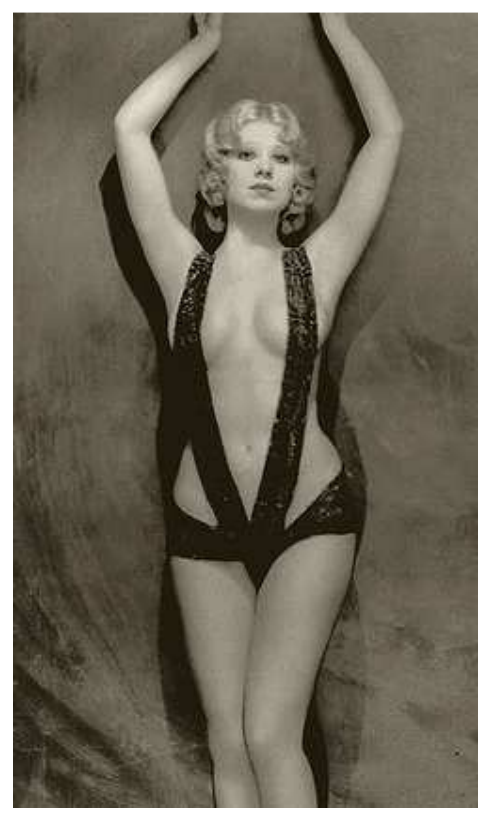


Shock value continued its wave through Act 2 with "If You Could See Her Through my Eyes," a commentary by the Emcee on love for fellow Jewish friends and lovers during the time of Nazi racism, anti-Semitism, and discrimination. The script called for his sweetheart to be in a gorilla suit. This production's design decorated our primate beauty queen with a pink brassiere and tutu, parasol, and "German" blonde braided pigtail wig. Intending the frivolous costume to further the lighthearted and ridiculous quality of the song, it also distracted the patrons from the true meaning of the song. They were brought to brutal understanding as the final lyric fell heavy on the audience's ears and imparted full shock value: "If you could see her through my eyes, she wouldn't look Jewish at all."

\section{KIT KAT BOYS and BAND}

The male performers in the Kit Kat Klub ensemble were a mystery to me as I sketched again and again, wondering what they would become. Professor Blair had requested that they perhaps show exposed skin like their female counterparts. At a loss, I imagined the boys in female corsets and lingerie, or in scandalously tiny shorts and sock garters that mimicked the ladies' lingerie outfits. Ultimately the three boys became minions to the Emcee in my mind, their exposed, low-cut tuxedo vests echoing his vertical striped pants. Choosing supportive yet stretchable fabrics for these active dancers was a challenge. A solution to overly restrictive tuxedo vests was achieved by building the back panel from stretch velour. The three saucy gentlemen only change into working class period costumes for the engagement party in "proper society" (Act 1, Scene 12).

For the nightclub's house band, I began searching through photographs of actual cabaret bands in the book Cabaret Berlin (Munz and Sieber). Mostly comprised of male musicians in tuxedos, a few had female singers in period evening gowns. A directive from Professor Blair alerted me to the possibility that large cross-dressing "German" men and glamorous women alike might fill these instrumental slots. Director Blair also referenced the stout "ladies" appearing alongside Marlene Dietrich in the 1930 film, The Blue Angel. Utilizing this guidance and photos of female chorus-lines in strange and outlandish themed cabaret costumes, I decided to take the comical approach and use the name of the nightclub to my advantage. A serendipitous image appeared to me in The Hot Girls of Weimar Berlin, a book about the sex and drug subculture during Cabaret's setting (Ulrich). The two dancers pictured had perfect cat shaped headpieces, and became my muse for Kit Kat Klub themed performance costumes (see Fig. 36). On a Halloween costume website, I was lucky enough to locate a source for black and gold geometric flapper dresses (in a stretch velvet that also came in plus 
sizes for potentially larger men). Thrilled to have the Kit Kat band prepared, I was eagerly awaiting the selection of musicians.

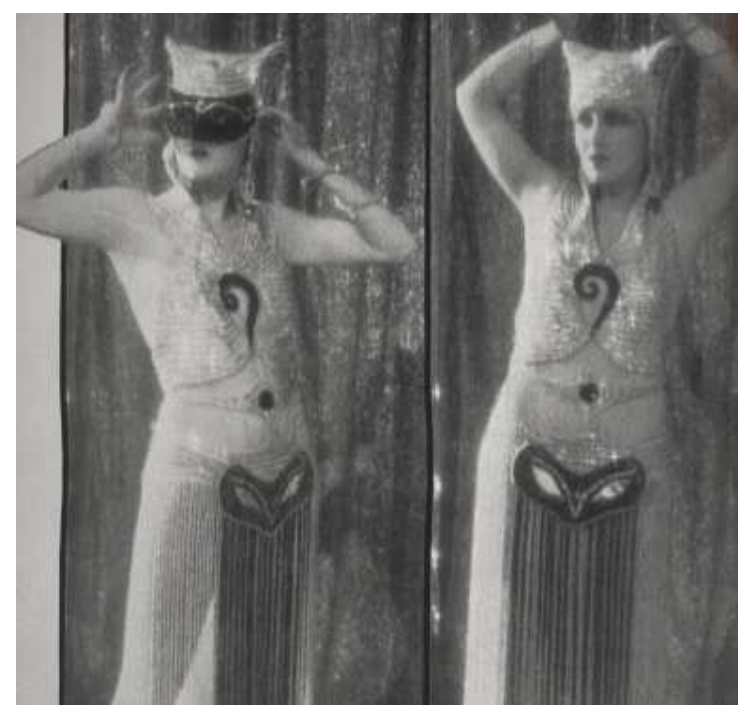

Fig 36: Two Cabaret club performers in mystery cat costumes

\section{NOTABLE SUPPORTING CHARACTERS}

Minor supporting characters inhabiting the Kit Kat Klub were comprised mostly of male club patrons attracted by the Vaudeville shows and feminine mystique. The club's proprietor, Max, was designed by channeling Prohibition-era gangster Alphonse Capone (see Fig. 37). He sported slick charcoal suiting and matching fedora. Royal purple accents appeared in his waistcoat/vest, pocket square, fedora band, and feathers. A pocket watch and cigar were finishing touches. In this production, the same actor played Max and the railway Customs Officer, who sported a blue uniform coat, officer's hat, and quick-change moustache.

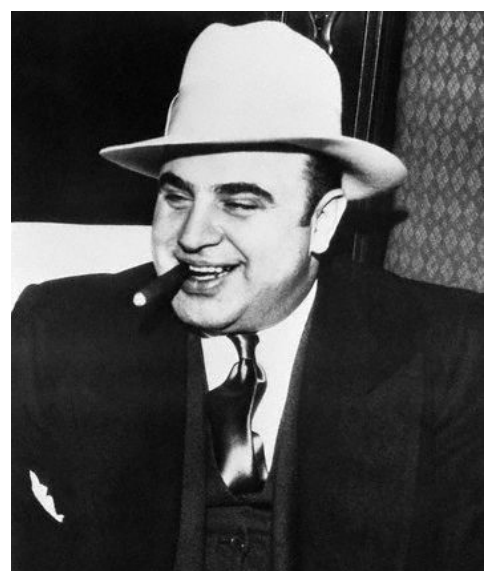


Five gentlemen served multi-purpose roles with functions such as Nazi Guards, the Taxi Driver, German Sailors and Male Club Patrons. The historic Nazi uniform chosen for this production of Cabaret was an early 1930's Schutzstaffel (Adolf Hitler's "SS" guard) protection guard uniform (Ruhl). The tan dress shirt, black jodhpurs, black jackboots, and black cross-belt were blended with a higher-ranking Schutzstaffel peaked cap for greater impact on the large Clay Concert Theatre stage (see Fig. 38).

Cabaret's sailor uniforms were inspired by vintage photographs of German sailors (see Fig. 39), but the blue woolen uniforms used in production were authentic World War II era US Navy uniforms on loan from Fairmont State University. The eagle insignia on the shoulder was remarkably similar to the German Third Reich eagle symbol (Davis). Inspiration for the Taxi Driver character was taken from a Shearling driving costume in the Sears Catalog Archive (Blum), and other male club patrons were outfitted with various neutral suiting combinations pulled from WVU costume stock (see Fig. 40).
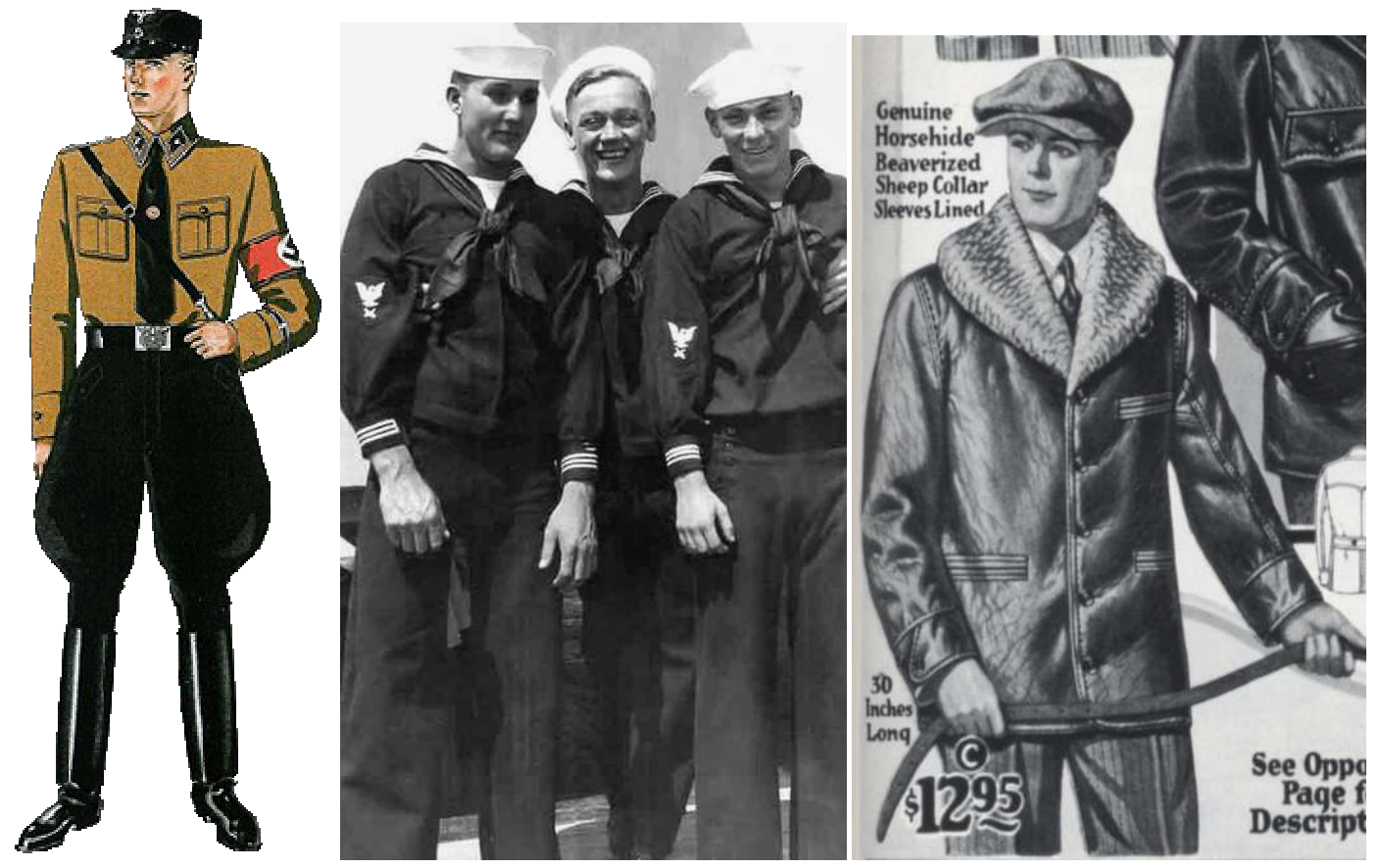

Fig. 38: Nazi Guards uniform inspiration, Schutzstaffel Guard

Fig. 39: Three sailors in navy blue uniforms, 1920's

Fig. 40: Taxi Driver inspiration, Shearling coat and Tweed cap 


\section{PREPARATION AND ORGANIZATION}

The production of large-scale musicals requires rigorous organization to keep track of details such as costume changes, actors with multiple roles, fitting notes, budget, orders, receipts, etc. In costume shops substantially larger than ours at West Virginia University the position of design assistant can fulfill this need and ease the workload stress for the main costume designer. This was not a luxury allotted to me during Cabaret, but a position that I came to better understand and appreciate while working in costume crafts at The Santa Fe Opera for their Summer 2013 season. Being part of such a large shop that handled five massive opera productions simultaneously, I was impressed by the level of order and paperwork that was required in Santa Fe's shop to make the machine function smoothly. Endeavoring to carry these lessons with me, the preparation and organization for Cabaret's costumes can be categorized as follows:

\section{EARLY}

- Pre-Budgeting and Shopping: To meet my budget approval deadlines, I was required to map out a budget and source many of my items four months before casting. While compiling this, it felt like a huge waste of time since many fabrics and other items I researched were no longer available when I came to the actual buying process. However, I did learn that this process is essential for establishing a budget framework and target zones for each group of costume items (fabric, dye, crafts, lingerie, Nazi uniforms, etc).

- Character Mapping: This encompassed deciphering exactly which characters we were creating and how many costumes and changes were required for each one. Initially, as is normally the case, this was a loose outline that further evolved after casting occurred. Additions to the script included female-to-male cross dressing club patrons, an older woman patron, a young blonde Nazi propaganda girl, and five concentration camp prisoners for the finale.

- Costume Research and Renderings: The design schedule was very tight before the end of the semester, and trying to work out details with the director left me with only finalized thumbnail sketches before summer. Utilizing the summer months ahead of me which was a luxury, I spent the time becoming very comfortable with my characters and craft renderings that I could be proud of.

A notable influence during my research and rendering period while striving to capture the mood of the play, I stumbled upon an illustrator working under the pseudonym Fyodor Pavlov. His work centered on period costume, queer sexuality, erotica, burlesque, and feminized men. A few of his pieces spoke to my project even 
further (see Fig. 41), with themes based on Anita Berber, Weimar Germany, and the 1951 John Van Druten play I Am a Camera. This play was the precursor to Cabaret (1966 Broadway production, 1972 film), and adapted from the short story-novel The Berlin Stories (1945) by Christopher Isherwood (Crowther and Erickson).

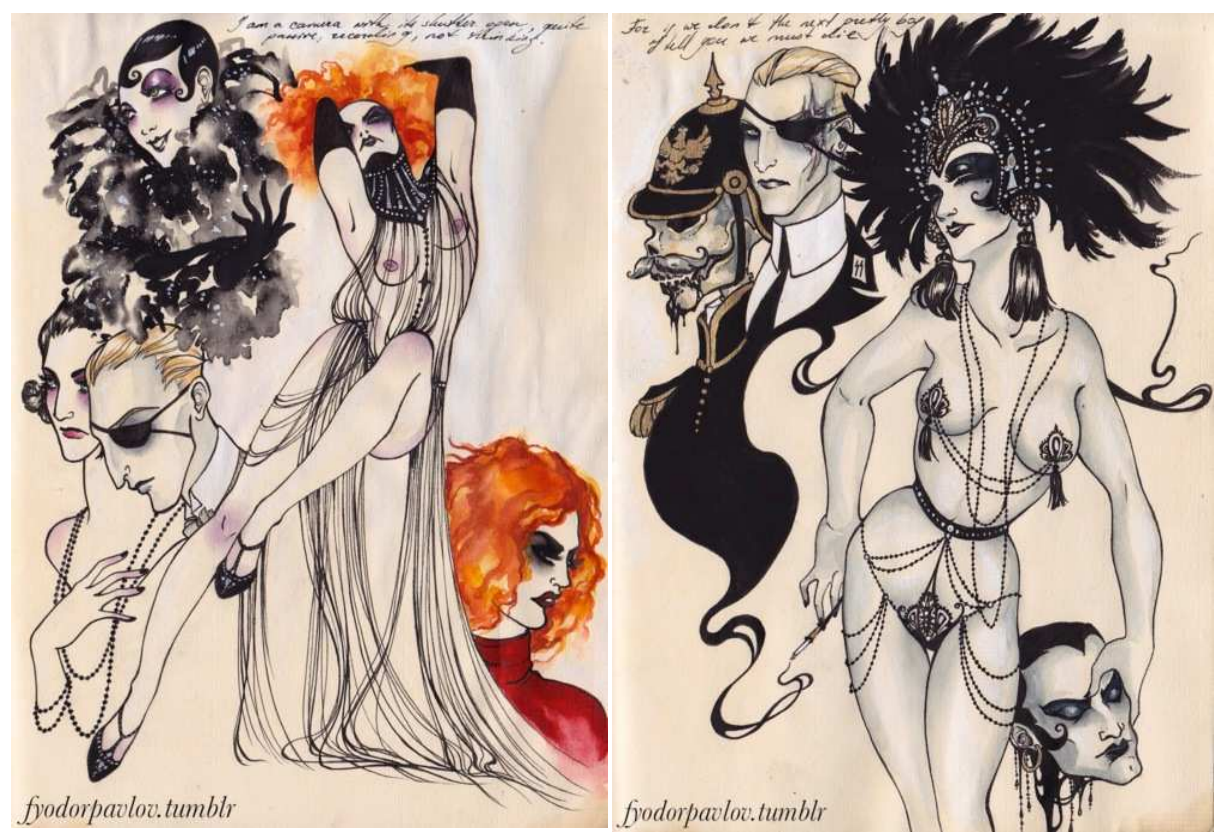

Fig. 41: Two Fyodor Pavlov Illustrations (presumably Anita Berber and Weimar Germany).

\section{MIDDLE}

- Pulled / Borrowed Costume Items: In an attempt to save precious and limited budget funds, I spent two solid weeks at the semester's onset combing every inch of our costume storage for overcoats, 1920's dresses and accessories, hats, men's suits, fabric, lingerie, shoes, furs, tuxedos, stockings, etc. During the design phase for a previous project, Blood Wedding, I felt that I did not use WVU's bountiful costume stock to fullest advantage, and I was vigorously determined to do so this time. These efforts were also an attempt to be prepared for early actor fittings.

Considering the difficulty of creating finger-wave and pin-curled hairstyles, I realized early on that every female (or female impersonator) in the show would need a wig. As a perk of being leading ladies, Sally, Kost, and Schneider all received custom ventilated wigs. Planning for the band ladies, the extras, and the numerous Kit Kat Girls required utilizing our wig storage. I was fortunate enough to discover many great blonde and brunette wigs that could be styled into the curly period shapes and that did not compete with Sally's dark red bob. 
These discoveries left me feeling successful but the amount of costume pieces still needed required that we look to borrowing and/or renting. Engaging in a new and necessary experience, Costume Professor Mary McClung and I called upon a number of fellow universities regarding costume loans and rentals. Successful contacts were made with Fairmont State University and University of Mississippi (Ole Miss). Fairmont graciously loaned our production many dresses that with a little manipulation could become similar to a 1920's silhouette, as well as authentic US sailor uniforms, and the infamous gorilla suit. Ole Miss shipped a large box containing a multitude of 1920's inspired pieces and Nazi jackboots with metal heels for goose-stepping. I was incredibly grateful to their faculty and staff for this invaluable generosity. The dresses from Fairmont were especially helpful since I did not wish to add these to our build schedule, and I had been hoping the simple sheath style would be easily located and altered to my needs.

- Ordering and Shopping: Keeping track of the infinite amount of items and fabric yardage I needed and the finite amount of money I was allotted was an ongoing challenge. Creating a spreadsheet to record all needed and purchased items, backup options, cost, and item location online was very helpful for this project (See Appendix IV). Our shop supervisor Sharon Goeres was also an indispensable resource for assisting me as a designer in tracking my production expenditures.

Although I was courteously extended the opportunity to take a fabric shopping trip to New York City's garment district, I did not feel like this would be the best decision for my design process. Understandably, many designers may consider this metropolis the fashion market of their dreams. Having only visited there once (and then only a two block radius), I knew that I would feel overwhelmed, rushed and uncomfortable in my decision making while trying to take in the wealth of material options around me. I feared that the prices I would find in New York would be far more expensive than local discount stores and websites, and that I would spend my allotted budget money too quickly. Preferring to take my time comparing prices online, I felt this was also a smart choice when designing a large musical on a conservative budget. Our team did have a successful and budget-friendly journey to the small Jo-Ann Fabric store in Bridgeport West Virginia. 


\section{LATE}

- Costume Shop Work Flow: Costume shop director Mary McClung and shop supervisor Sharon Goeres were invaluable in dividing up the initial workload among the shop. I did try to make an original spreadsheet of every costume item or group that needed to be built, bought, or altered, but Professor McClung organized it into a chart split for every worker on our build team. Everyone has their own system of attacking a to-do list, and Sharon and Mary have turned these breakdowns into a science for our costume shop.

With Professor McClung acting as the production's head draper, each team member had a set of items to see through the shop from start to finish, whether it was in their own hands or those of our costume lab undergraduate student stitchers. As a modest-sized shop, our designers are responsible for various functions during their show's build. Some of my Cabaret assignments included; silk painting and building Sally's kimono, all fabric dyeing and preparation, over-seeing and co-building all crafts and accessories, garment painting and distressing, conducting fittings and setting up their subsequent alteration notes, setting up costume lab work, and being available to answer all team questions and concerns.

- Designer Binder Notebook: This volume was my guidebook and the binder became attached to me for the semester like a fifty pound brick. Holding the shreds of my sanity together with its shiny metal rings, the notebook contained all the information pertaining to the costume realm of Cabaret. Some topics included within this were cast measurement sheets, cast and crew contact information, a hard-copy PowerPoint presentation of research images, costume build spreadsheets, order receipts, budget tracking sheets, color copies of the renderings, makeup designs, and to-do lists (see Appendices I-IV for paperwork). Keeping a well-organized designer binder is vital to the smooth workflow progression and construction of any theatrical production.

- $\quad$ Paperwork: Some notable paperwork that occurred later in my design process contains information vital to the performance of the musical and the wardrobe crew that kept it looking fabulous. The costume piece list and laundry list are the classical guides for dressers, helping them to know every item that should be on their costume rack and how to maintain it (See Appendix II). I typically create makeup design and hairstyle (for nonwigged actors) sheets after much of the costume design has been pulled together and as I become aware of further character needs(See Appendix V). A novelty to this show was my use of costume track spreadsheets inspired by the ones used in The Santa Fe Opera's costume shop. With so many fast-paced quick changes and musical numbers, I decided that these detailed documents were necessary for this production. Not only to 
communicate and clarify the costume plot to everyone backstage, I needed these charts just to remember who I wanted to wear what and when (See Appendix I)! Hoping to create goodwill and a calm, confident cast and wardrobe crew was only an added bonus, but seemed to be a successful and appreciated initiative during dress rehearsals. 


\section{BUILD PROCESS}

\section{Shop Management and Work Flow}

In order to handle a show of Cabaret's considerable size, our small costume shop prioritized which items we would custom build and which costumes could be created from bought and altered pieces. Major construction on garments listed as follows:

- Sally Bowles - fur coat, teal day dress, kimono, purple cocktail dress, gold evening gown, reconstructed blue leotard

- Fraulein Schneider - burgundy house dress, cream skirt suit, quilted robe collar/cuffs

- $\quad$ The Emcee - green corset, striped knickers, baby bonnet and thong diaper

- Gorilla - pink bra with foam understructure

- Kit Kat Chorus - boys' three striped vests, one mint green cocktail dress

- Fraulein Kost - red flapper cocktail dress (major alteration)

In addition to this list, the bulk of our build schedule was filled with alterations, embellishments, and lots of craftwork on hats, accessories, jewelry, and garment painting or distressing. The craftwork was to be split between myself and an undergraduate, Kelsey Musselman. The majority of the crafts eventually fell on my shoulders (or Professor McClung's) when Kelsey failed to complete many of her assigned tasks.

To help keep our team on track over the course of the build, the costume director and shop manager created multiple versions of itemized build lists and schedules, adjusting the lists as the build progressed and items were completed. Together the three of us kept up with the progress of all items worked on in the shop. After discussing the concept and actors desired in PR photos with Director Lee Blair, it was decided that The Emcee and seven Kit Kat Girls (including Kost) would be the subjects. Therefore the chorus' lingerie and The Emcee's corset and knickers outfit became a top priority for finishing. Two of Sally's dresses were created by students in Advanced Costume Construction class and Fraulein Schneider's cream skirt suit was built by senior undergraduate Margaret Lazenby. Graduate student Randall Browning served as wigmaster (also a costume cutter/stitcher), managing two undergraduates in the ventilation of our three leading ladies' wigs and the styling of all twenty wigs in the production. It was decided that Sally should have two identical red wigs as a backup plan in case quick changes or dancing spoiled her hairstyle by intermission.

As costume designer and team leader on this project, I did my best to stay on top of delegating the workload and managing the progress of all items in the shop. The first few weeks after casting left me buried under fabric dye preparations and alterations set up from 
early fittings. With thirty-two actors in the cast, it felt like I was racing to cram everyone in so that I could stay on schedule and keep supplying work to our costume lab students and shop staff. As a result of pushing myself so hard and spending long hours in the shop early on, I became sick in late September. Thankfully I recovered quickly and the resourcefulness of Professor McClung and the shop staff compensated for my absence. I assume this was the course of events as I was not there to witness the large amounts of progress that had magically occurred when I returned.

A project that I took on against better judgment was Sally Bowles' hand-painted silk kimono. Craving to use my newly acquired skill of silk painting, I signed on to build the piece. Fellow stitcher Gretta Hemplemann assisted me when building the body of the complex robe made of temperamental silk charmeuse. Although thrilled with the end result, it was time consuming to stretch each section of Habotai silk (see Fig. 42), paint the butterfly and floral motifs, cut them out, then heat fuse (by ironing) and reinforce all the pieces to the robe with stitching (see Fig. 43, 44).
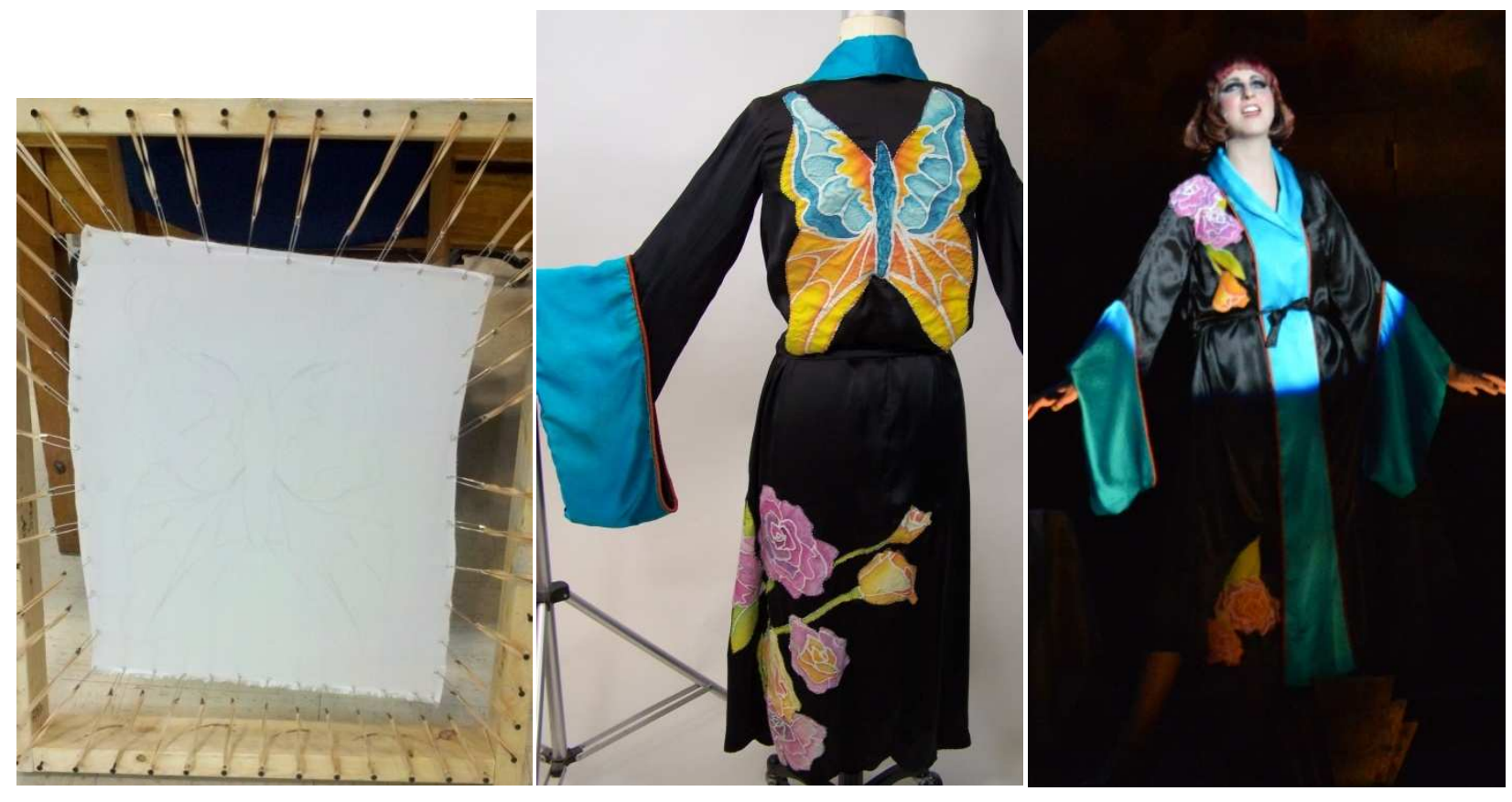

Fig. 42: Silk stretcher frame with Habotai silk prepared with resist lines and ready for paint

Fig. 43: Back detail of finished kimono

Fig. 44: Sally Bowles wearing her kimono on stage in final scene of Cabaret

Most garment alterations and construction items moved through our "factory" in a timely manner, but there were a few places I now feel like I should have pushed a bit harder. Our undergraduate workforce seemed to drag their heels on many projects, leaving the shop work flow still buried deep in Cabaret when we were supposed to be starting work on projects for the next production, The Liar. Numerous meetings were held amongst our costume shop faculty 
and staff when this was discovered. The solution we arrived at was that the graduate students needed to keep a closer watch on the general progress of work in our lab classes. I am still not sure whether this would have helped, or how to get students to sew faster if they do not wish to be engaged in costume work.

\section{Evolving Pieces}

Theatre is an art of process. An excellent observation of this can be found in the evolution of costume pieces. After borrowing all of the cocktail party dresses for the Kit Kat Girls during the engagement party scene (Act One, Scene 12), there was still one actress, Sara Gianola, for whom we could not find a dress with a flattering fit. Since 1920's sheath dresses are relatively simple shapes to drape and sew, the decision was made to build her a custom dress directly from the rendering of the girls for that scene. After reviewing all the other pulled pieces that had been chosen due to actor fit and overall color scheme balance, I chose the mint green dress with darker diagonal flounces (see Fig. 45).

The same actress had injured her ankle early in the rehearsal process and as a result, was unable to perform in the intense and high-impact Kit Kat Klub Nazi kickline (Act Two, Scene 1). I was not informed until very far along in our build process that she had been replaced in the kick-line with male dance captain Adam Messenger. Thankfully he had already gone through a fitting with a blonde female wig for his cross-dressing appearance in "Two Ladies." After an additional speedy fitting and check to make sure Sara's Nazi burlesque costume would fit him, Adam was ready to lead the Kit Kat dancers in the goose stepping dream sequence.

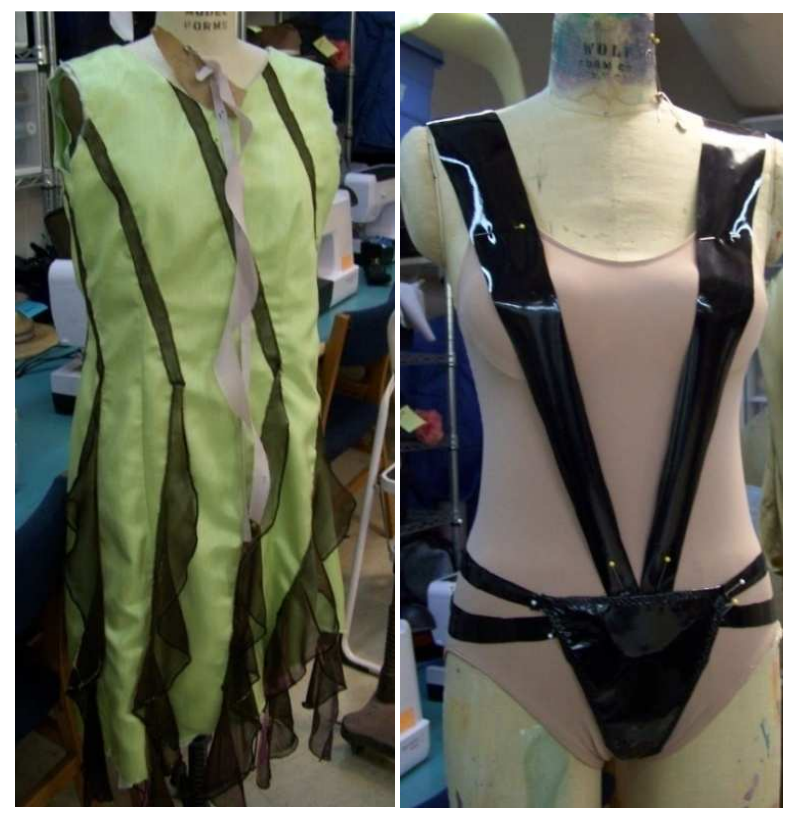

Fig. 45: Mint green dress in process for actress Sara Gianola

Fig. 46: Burlesque leotards for Kit Kat Klub Nazi kickline 
Creating multiples of items for large chorus dance numbers is always a time consuming activity, and the Nazi leotards were not the only pieces that were time-costly (see Fig. 46). Assuming that I had invented a simple solution to the Erté inspired accessories for the Kit Kat Girls in "Money" (Act One, Scene 10), the shop pushed ahead in whipping them together while I was absent from the shop with illness. The fishnet armbands were draped with strings of gold Mardi Gras beads and were quickly sewn together. When I returned and met with the Director and Choreographer, I was informed that the beads would impede the demanding choreography in the number. Due to the armbands' dramatic nature and the action required, the decision was made that the beads needed to be removable with Velcro for the second movement of the dance number. Re-working this change imposed a huge and unforeseen dent in the build time budgeted for the show and in hindsight should have been prepared this way the first time the beads were sewn on.

The "Money" song also utilized the exotic trend that emanated from this period with coordinating "metallic" headpieces for the Kit Kat Girls. These were worn throughout the entire song and did not cause any choreography interruptions, but they were also a bit time consuming to build. Crafts artist Kelsey Musselman and I partnered on this project: she created a plaster mold from a clay sculpt of the "metal disk," and I poured a liquid neoprene slush-cast for each disk (see Fig. 47). Once dried and set, the fourteen disks were sewed to seven thermoplastic Varaform headbands. Finishing treatments included gold paint, gold beads and center front decorations that I crafted from Fosshape, another thermoplastic product (see Fig. 48).

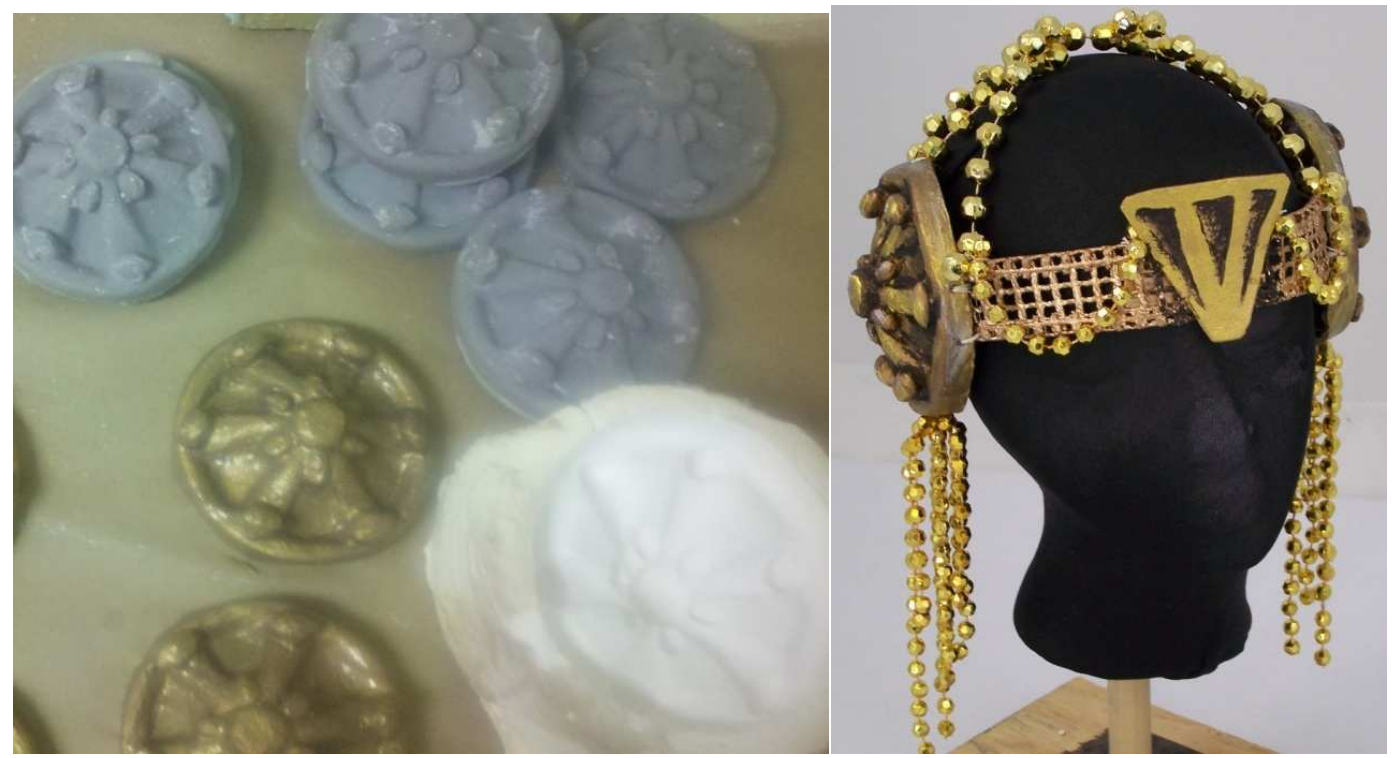

Fig. 47: Plaster Mold, cast gray Neoprene disks, some with first coat of gold paint

Fig. 48: Finished headpiece for "Money" song 
Although Sally Bowles' costumes encompassed the majority of the "whole costumes built," their impact on stage was worth the time spent to create a perfectly brassy starlet. The gold and black silk charmeuse Erté-style gown that was designed for the climax song "Life is a Cabaret" took many hours of construction work by shop manager Sharon Goeres. Sharon and I labored over the details of this deceivingly complex dress, knowing that we wanted it to be truly perfect for Sally's big finale song (see Fig. 49). The train, asymmetrical belt, arm swag, and sun ray shaped sequin embellishments were an evolving process as we worked and re-worked them to attempt perfection. The scale of the sequin appliqué was an especially difficult challenge to solve, and kept me in the shop numerous late nights to arrange, re-arrange, and stitch all the diminutive pieces and sequins on (see Fig 50). Her coordinating fosshape tiara also evolved from having an Erté-motivated-spire-centerpiece to having no spire at all. After every dress rehearsal, Director Blair requested the tiara be trimmed down more until there was nothing left of the spire. The tall spire was evocative of Erté's dramatic style but was visually distracting from the full effect of the gown (see Fig. 51). I thought the piece impressive and that it provided completion for her outfit so I was slightly upset at first. But after adding extra sequins and seeing it a few times with the gown, I was satisfied with the completed visual concept and the Director's decision.

Sally's infamous fur coat also evolved to have large inner pockets added so she could store the ingredients for her trademark hangover cure: real eggs and Worcestershire sauce. This is a necessary action dictated by the script, but I was worried that the eggs would break

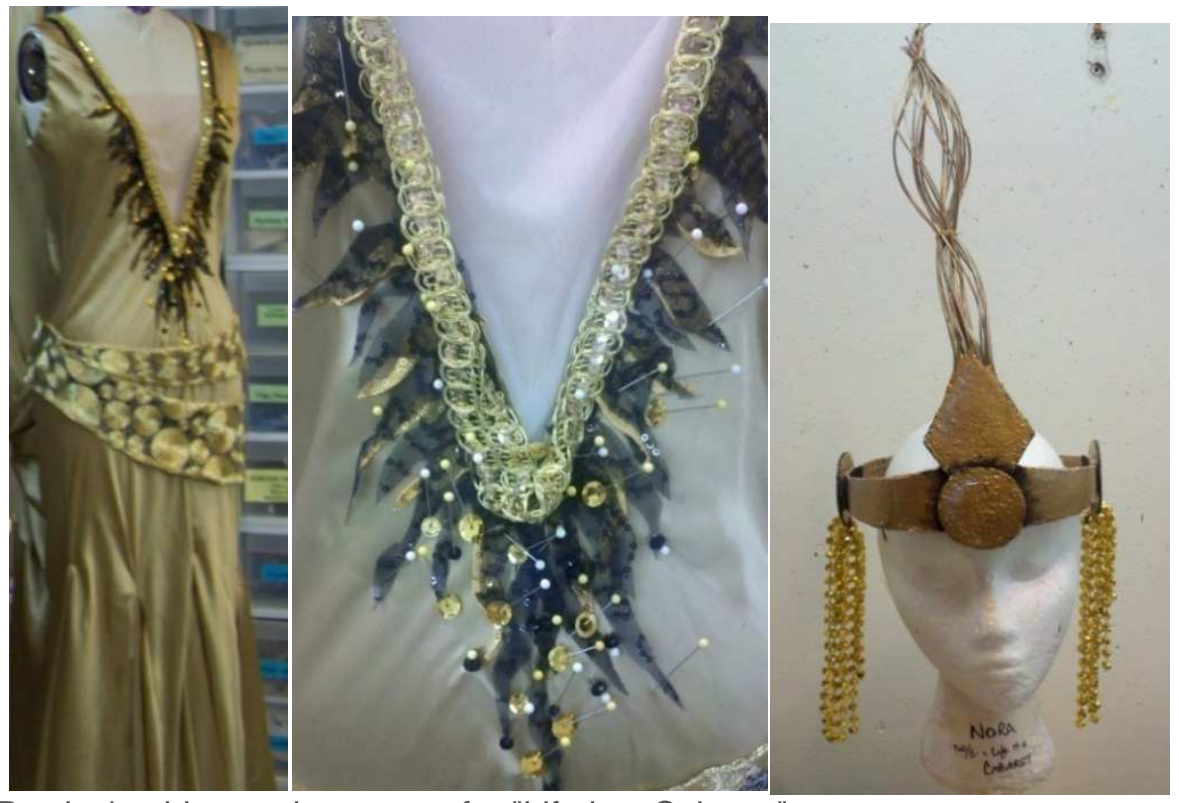

Fig. 49: Sally Bowles' gold gown in process for "Life is a Cabaret"

Fig. 50: Detail of Sequin Appliqué on gold gown

Fig. 51: Original Erté tiara for Sally Bowles ( before spire was cut and sequins added) 
inside the pocket and ruin the showpiece fur coat we had labored over. Therefore I coordinated with props master Joseph Dotts to have the pockets double lined with plastic and padded out. The scene went as planned and the showpiece fur coat was safe.

Patience and understanding were put on the line when actor Mark Combs was cast in the role of Ernst Ludwig and then immediately came to inform me he planned to lose sixty pounds or more in body weight before show time by juice fasting. Outside of academia, an actor could easily be fired for altering their image from when they were originally cast. Worried that I would have to wait very late in the build period to purchase a suit, I knew I was risking issues with shipping and time frame. There would be no time to correct fit or return the suit if there was a problem. Director Blair reviewed my concerns with the actor, and determined that the root of this was Mark's true health and well being. Allowing the actor to improve his health and lose the weight, I would order the suit as late as possible. Mark did not fit into any of our pinstripe suits from stock and I knew I would have to order one online, probably costing in the range of 100 to 300 dollars. After finding the perfect navy blue, three-piece-suit with a wide ice blue pinstripe in our stock, I had my fingers crossed that it would be the perfect fit. First fittings revealed that it was far too small, but three weeks before opening we tried it again. It was a perfect fit! Seeing Mark looking sharp, dapper, proud and genuinely happy with his appearance was worth any hassle or headaches the situation caused (see Fig. 52).

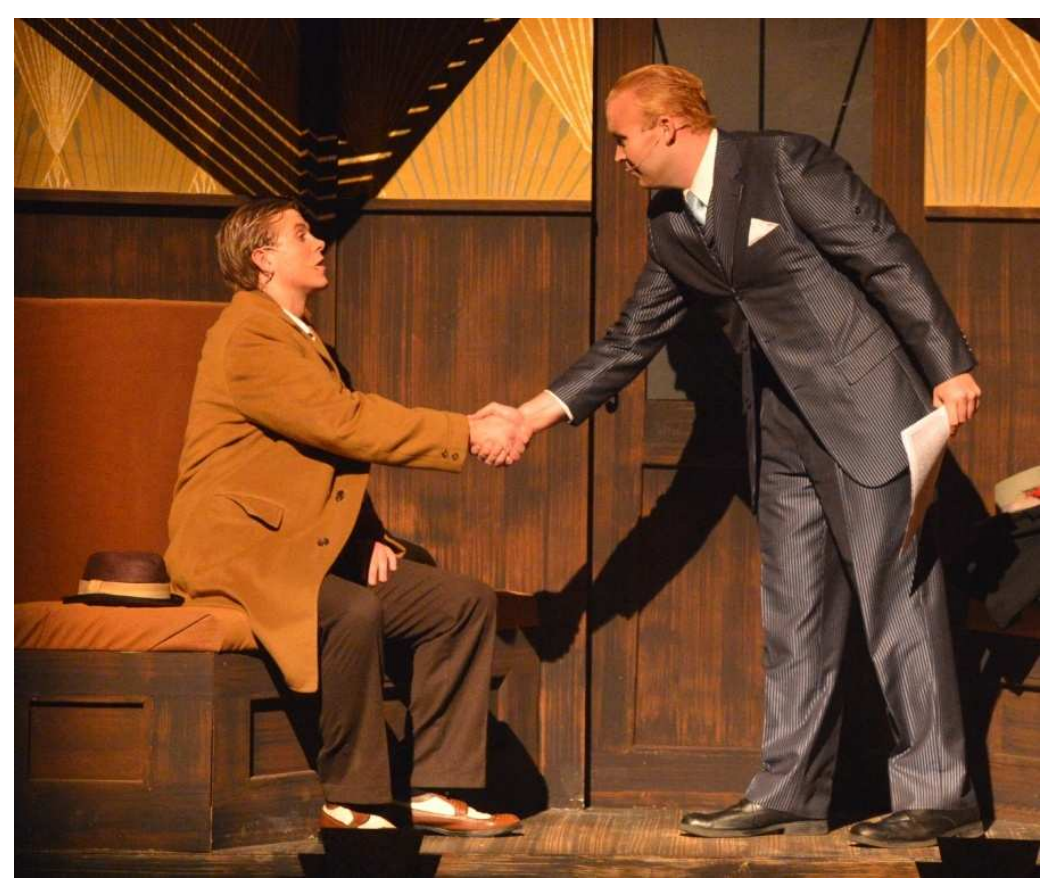

Fig. 52: Actor Mark Combs as Nazi supporter Ernst Ludwig (at right) 
Rehearsal shoes always seem to be an issue in our costume shop. Some directors demand that we provide actors with the actual shoes for the production far too early, resulting in ruined shoes by opening night. We occasionally concede to these requests for actor safety if the shoe is a specific or strange shape. Professor Blair and Professor McClung and I agreed early on that as a musical theatre cast, the actors and dancers should be professional and have their own character or jazz shoes. Since so much of the rehearsal process centered on choreography, getting used to their own dance shoes was essential for their comfort, safety, and a big relief from my modest $\$ 4500$ budget. However, as part of his design I envisioned the Emcee wearing tall-heeled boots and to help him develop the character, actor Vincent Pelligrino was provided with a pair of black velvet boots. Unfortunately, because we are unable to buy good leather shoes, the synthetic boots stretched out to almost two sizes throughout the rehearsal process and had to be replaced by a shorter and less ideal pair of boots.

Vincent's other costumes and burlesque scenes were enhanced by Professor McClung's experience with designing for the Clay Theatre stage. Since I was a novice in this area, she lent advice on the scale of costume items pertaining to comic impact. Demonstrating the dimensions required for maximum laughs, Mary built the baby bonnet for the New Year's Eve stunt (Act One, Scene 4) and the Gorilla's pink brassiere for "If You Could See Her Through My Eyes" (Act Two, Scene 3). Up close in the shop, the two pieces almost seemed overly large, but on stage they were a perfect and a hilarious hit with our audiences (see Fig. 53-54).
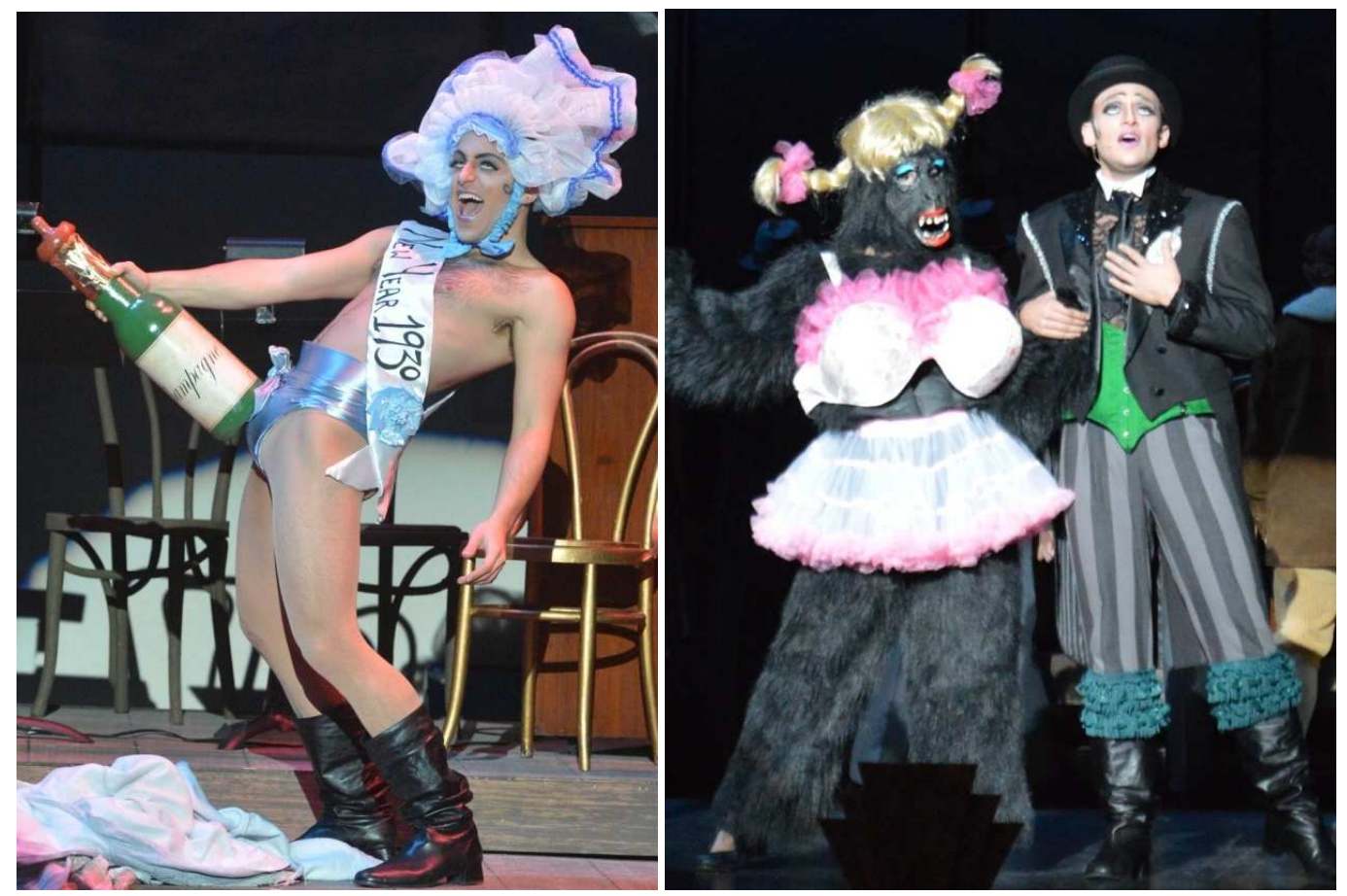

Fig. 53: Vincent Pelligrino as The Emcee in Baby New Year costume 


\section{Communication}

Overall the communication between costume shop, design team, stage manager, cast and directors went very smoothly with only a few occasional hitches. Everyone was open, willing to be flexible, and I felt confident in Director Lee Blair's leadership and ability to mediate any issues. Knowing how complex the scenes would be, Director Blair brought me a chart of which characters he was hoping to block in which scenes (See Appendix III). I was grateful to receive this spreadsheet early in the semester, and after casting there was more discussion about which actors were in multiple roles and how to streamline their costume changes. For example, the supporting characters with titles such as "Man \# 1" were often assigned up to four different roles to fill: Club Patron, Nazi Guard, Taxi Driver, Sailor, etc. Attending rough rehearsals helped immensely regarding who-wore-what and when. Stage management was vital in assisting to track this information and keep everyone on the same page.

One great learning experience that has lingered in my memory was dealing with gossip and rumors leaked by actors. Enthusiastic about their roles, their costumes, and things Director Blair may have said offhand during rehearsals, they would repeat this stream of newfound knowledge and concerns to me unfiltered during fittings. Usually it would regard an accessory they required for a musical number or being confused about how many different roles they were playing. In turn, I would be shocked or concerned if it sounded like a major change or addition had occurred during rehearsals without my knowledge. Wanting to stay on top of the mass workload in the shop and feeling as though I had missed some major component of the script, I would take the rumors received to weekly production meetings for review. Director Blair assured me that I should focus only on information given to me through Jackie Merrill, Stage Manager or directives straight from himself.

Communication and my fundamental knowledge of lighting design principles also helped me to avoid a fabric dyeing catastrophe. I was preparing yardage of silk velvet for Sally Bowles' purple cocktail party dress, and was testing swatches in a bath of red-violet eggplant hues. It suddenly dawned on me that Sally and Fraulein Kost were two of the leading characters in that scene, with Sally in purple and Kost in bright red. If my lighting designer Tim Thisleton chose strong red or blue gels, the color of their dresses might be reversed or they might even look exactly the same! Quickly phoning Tim, we discussed his lighting plans for the scene and the shade of purple that I should dye the velvet. I needed a blue-violet and not the reddish purple I had simmering away in the dye pot. Although I had to pour out and waste a large batch of redviolet, I was very thankful to have realized the potential mistake and correct it before it was too late (see Fig. 55). 


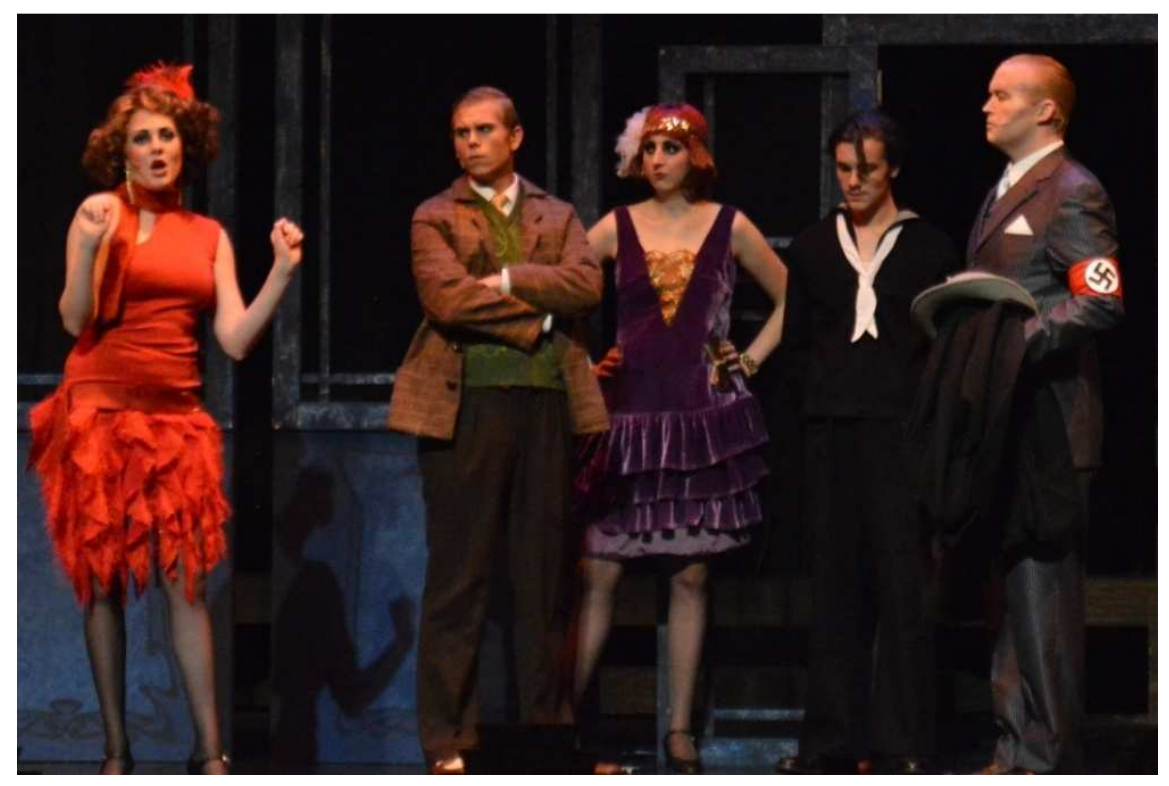

Fig. 55: Red and purple dresses playing amiably together during "Tomorrow Belongs to Me" 


\section{PERFORMANCE}

The dress rehearsal process and production run were swiftly completed in one week on the Clay Concert Theatre stage. Three dress rehearsals and three days of production seemed to end all too quickly for the amount of work and effort put into the show. The actors and wardrobe crew seemed to be in high spirits and had a positive team attitude backstage, which I attributed to their enthusiasm about the production. I was incredibly proud of our dresser crew, who did a fantastic job running a complex and high stress, high pressure production.

To ease the pre-curtain time crunch and lessen any stress in the dressing rooms, the costume shop held its normal wig-training session the Saturday before first dress rehearsal. With the hope of elevating the level of backstage practices to match most other professional theatres, a mandate was issued to all actors receiving wigs: arrive at call time with hair pre-pin curled. The training session covered pin-curling techniques and allowed dressers to practice fitting actors with wigs and accompanying headpieces. Minor panic ensued as many of the ladies were not used to seeing their hair chopped and slicked into vintage finger-wave styles, but this was much abated the next day after donning their lingerie and seeing their completed costumes and characters. A separate training was held for the four Kit Kat Band ladies, who were all instrumental music students with very different schedules from the majority of the cast, composed of mainly theatre and vocal department students.

Primarily wig maintenance encompassed the cementing of curled hairstyles and fingerwaves that would stand up to vigorous dancing on stage. Sally Bowles' red bob wigs were a challenge to maintain, as the headbands and tiaras created for her ensembles kept dragging down the volume of the short style, resulting in a very unflattering pageboy. Solutions included restyling and pinning restrictive hairnets under the edges of the curl to keep it elevated and protected. The only natural hair issue of note was a last minute haircut by Professor McClung for Ben Forer to groom him to the status of club owner and government official (Max and the Customs officer, respectively).

Despite the size of the production and the number of costumes involved, the amount of post-rehearsal notes that the shop received was relatively minimal than expected. Minor repairs, quick-change rigging, wig maintenance, and opera shading to enhance the depth of certain pieces were all manageable adjustments. At Director Blair's request, The Emcee's carefree, bold and bare countenance was darkened in Act Two with the addition of a black lace shirt and tuxedo coat embellished with sequins and sparkles. The rehearsal evenings passed smoothly with the greater issue facing the cast and crew being mastering choreography and scene changes. Production designers watched the action from the house, available to their colleagues should any questions arise. An example of this collaboration and considerate behavior was my interaction with Lighting Designer Tim Thisleton regarding the spotlight during 
Nora Perone's (Sally Bowles) solo, "Life is a Cabaret." The focus on the beam was so tight around her upper body; it blocked the full effect of the long golden gown that glowed on Nora from head to toe. Tim completely understood my concern and willingly indulged my request by gradually widening the spotlight as the actress approached the audience downstage, revealing the entire gown.

Although the designers worked together amiably, a harsh experience was wrought elsewhere backstage. The night after first dress rehearsal, graduate wardrobe supervisor Randall Browning claimed that during the laundry cycles a pot of brown dye had fallen from its seat atop the dryer and splashed all over the costumes being washed. Apparently he then stayed up all night cleaning the laundry room and all costume pieces affected. Early that morning, he sent an e-mail to the staff of the costume shop and the Chair of the Theatre Department declaring that he had spent far too long on my thesis production and now needed time for his own personal project. I was thankful for any rescue he offered to my costumes, but was deeply offended and betrayed that my long-time friend and colleague would abandon me that close to my important thesis production opening. With my graduate wardrobe supervisor and wigmaster deserting his post, the only option was for me to take over backstage as well as being the observing designer from audience level. I was incredibly thankful for the solid leadership that undergraduate wardrobe supervisor Taylor Rouse showed in Mr. Browning's absence.

Due to the aforementioned mishap, I was slightly more present backstage than I should have been as the costume designer. However, it felt appropriate to be so deeply involved in my graduate thesis production. If having the roles of costume designer and graduate wardrobe supervisor weren't enough to foster this feeling of pride and ownership in the production, I was also able to assist with the rigging load-in of suspended scenic elements. Part of graduate student requirements for Technical Director and Professor Steven Neuenschwander's Rigging course was to participate in the load-in of Cabaret. My assignments included fly-rail operator and working with the suspension hardware for Schultz' fruit shop windows and the electrified "Cabaret" hallmark sign. Being able to sit between my mother and my husband during Saturday night's show was an emotional experience. The amount of pride I felt to share that moment and showcase seven long months of bone-weary hard work and deeply personal artistic involvement with two of my dearest was indescribable and overwhelming. 


\section{SELF EVALUATION}

\section{Positive Experiences}

Overall costume shop management, communication, build process tracking and work flow progressed well. I attribute this to Sharon Goeres' expert organization and management skills, Mary McClung's speed pattern draping, and my being prompt and prepared with fabric preparation, alteration notes, pulled items, and trying to keep items set up for lab. I felt confident in most fabric choices and decisions I made in the shop. Working at Santa Fe Opera the summer before this production left me feeling very confident, professional, and ready for any challenge.

I was thankful for Professor McClung's advice on the scale of comedic pieces and general advice throughout the design process. I was very pleased with their hilarious results on stage and positive audience response that I observed during dress rehearsals and the Saturday night performance. Professor McClung was also key in arranging the borrowing of costume pieces from Fairmont State University's costume stock. Meeting Fairmont's theatre faculty and pulling from an unfamiliar costume stock was a new and positive experience.

When working with my actors during fittings, it was rewarding to see that the majority of the cast was excited about the show, their costumes, their roles, and all were on board with the period design concept. I was thrilled to be able to design female-to-male cross dressers as well as male-to-female. This only occurred because Director Blair needed more males in the cast as club patrons, and not enough suitable male performers attended auditions. The female roles I refer to included: Willa McWhorter as tuxedoed Maître'D, Jessica Donahue and Nicoletta Ciampa as a masculine lesbian couple in men's clothing. Despite very complex costume changes and actor role changes, communication between Director Blair, Jaclyn Merrill (Stage Manager), and I stayed open and we tracked the information adequately.

After viewing the complete production together on stage, I was satisfied with the overall costume concept, color schemes, and random happy accidents that occurred between my work and that of Scenic Designer Jane Ryan. These included similar art deco and geometric motifs that were used on some of my female accessories and the footlights, train car, and club bar. 


\section{Lessons For The Future}

The build process was fairly smooth for the size and scope of this musical, but the costume lab management could have been a little tighter, and their working speed should have been faster. The design's requirement of building multiple sets of certain accessories (especially the "Money" arm bands) set us back in terms of time-management. I could have pushed harder in these areas, as well as with motivating workers that were slipping behind in terms of the build schedule, such as craft artist Kelsey Musselman. Kelsey's neglect of her craftwork duties piled loads of extra work and stress on me and on the costume shop. Perhaps checking in with her on a daily basis or being more strict would have helped, but again; I cannot force people to come into the shop and work. On a personal constructive criticism note, I probably should not have taken on the full build of Sally's kimono robe, as it distracted me from other shop projects and craftwork.

Wigs played a central role in defining the female characters in this production. Sally Bowles' (actress Nora Perone) wig was the perfect red color, but not the shape I had envisioned. It continued to lose its volume and shape, although Professor McClung did attempt to revive it at least once. I believe that this was due to the wig not being cut short enough, the headbands and accessories she wore, the loss of the head wigmaster, and the high quantity of wigs that needed styling for the show. I also wish I could have replaced Ashley Koon's wig for the role of "Young Girl." It had been fried in the wig dryer and the result was a frizzled, puffy afro. I had many notes to deal with prior to dress rehearsals, and by the time I got around to dealing with the wig, I was informed by Professor McClung that it was too late to change it.

A constant personal challenge of mine was balancing my personal care with my work load and not over-working myself, so I wouldn't become ill during the costume build or immediately following productions. Just as prioritizing my health is a learning process, I find it difficult to decide what is able to be accomplished in a certain time frame, and what must be trimmed or edited so that the overall design does not suffer. Some character accessories that I had originally drawn did not make it on stage for the actual production due to the lack of their importance or being cumbersome for the actor. These included: a fur muff for the "Older Female Club Patron," cartoonish clocks and walking staff for "Father Time," painted argyle pattern on the socks of the "Taxi Driver," and six black garter armbands for the Kit Kat Boys.

Although those items were sacrificed, I learned the importance of giving actors adjustment time for extreme or unfamiliar costume issues. I wish I had been able to provide Nora Perone with a rehearsal gown for her finale complete with train. She was not very comfortable with her gold gown during dress rehearsals, and almost tripped on it once during 
her important finale solo, "Life is a Cabaret." Terrified and anxious, she borrowed the dress from the shop to have a private practice session on stage. This should not have been left so late, and she would have been less stressed and nervous.

Patterning and complex garment construction techniques have been a focus of my learning process while in graduate school. But as with many things, one always has room for growth. My inexperience in this area played a role in two patterning components that did not occur due to poor communication on my part with my draper: Sally's purple velvet dress and her fur coat. The purple dress should have had a draped cross-wrap from the bust to the waist, which ended up only as a complex seam that caused the stitcher un-necessary hassle and confusion. The fur coat was supposed to have a drape and large gold tassel on the back, but in reality was only smooth. Professor McClung and I discussed adding the tassel, but it became less vital as we approached opening night.

A design decision that acted as a learning experience was the development of the Nazi girl kickline costumes. In hindsight I feel that the outfits were out of place due to my use of black pleather. I desired an homage to German dominatrix and S\&M culture, but it strayed too far into the modern from the production's vintage 1920's theme. Perhaps my imagination went too far into the fantasy realm and away from connection with the time period. Professor McClung and I discussed that it could have been adjusted by adding fringe or using a different sparkly fabric. Director Blair had requested a "Scantily clad, nearly nude Nazi Girl." It was a burlesque of the Nazi uniform (based on an old period photo) that did achieve the military guise and shock value required. The design was definitely sexy and interesting, but not successful on every body type we created it for.

Initial budget projection totals informed me that I required $\$ 5000$ for costume production. I was originally offered $\$ 4000$, and I negotiated Cabaret's costume budget to $\$ 4500$. The project's final cost totals were slightly over the original projection of $\$ 4500$ by $\$ 217.24$. I believe this is attributed to the current high costs of dry cleaning, and a few shared costume shop expenditures that I wasn't expecting to be taken out of my budget. Cutting back on some of the fabric yardage I purchased (particularly for Sally's fur coat and gold dress decorations) would have also assisted in budget control. I was also misguided by my Wigmaster into thinking I was purchasing wig supplies for two productions (Cabaret and The Liar) at Sally's Beauty Supply. Upon returning to the shop I was told I could not split both receipts and the full total must be taken out of my show's account. This was the largest costume production budget I have ever managed and overall I felt that the funds were spent wisely to obtain the materials required to realize the design. 


\section{BIBLIOGRAPHY}

Blair, Lee. Production Design Meetings. West Virginia University, Morgantown. Personal Interview. Apr 2013.

Blum, Stella. Everyday Fashions of the Twenties: As Pictured in Sears and Other Catalogs. New York: Dover Publications, 1981. Print.

Crowther, Bosley, and Hal Erickson. "I Am a Camera Review Summary." New York Times 08091955. Web.

Davis, Brian Leigh, and Pierre Turner. German Uniforms of the Third Reich. New York: Arco Publishing, 1980. Print.

Dirix, Emmanuelle, and Charlotte Fiell. Fashion Sourcebook: 1920s. London, England: Fiell Publishing, 2011. Print.

Fosse, Bob, dir. Cabaret. Writ. Joe Masteroff, Jay Allen, and Christopher Isherwood. Allied Artists Pictures, 1972. Film.

Gordon, Mel. The Seven Addictions and Five Professions of Anita Berber: Weimar Berlin's Priestess of Depravity. Washington: Feral House, 2006. Print.

Gordon, Mel. Voluptuous Panic: The Erotic World of Weimar Berlin. Washington: Feral House, 2008. Print.

Hazanavicius, Michel, dir. The Artist. Weinstein Company, 2011. Film.

Laikin-Funkenstein, Susan. "Anita Berber: Imaging a Weimar Performance Artist." Woman's Art Journal. Vol. 26.No. 1 (2005): 26-31. Web. 16 Feb. 2014. <http://www.jstor.org/stable/3566531>.

Lareau, Alan. "The German Cabaret Movement during the Weimar Republic." Theatre Journal. Vol. 43.No. 4 (1991): 471-490. Web. 19 Jan. 2014. <http://www.jstor.org/stable/3207977>.

Laubner, Ellie. Fashions of the Roaring 1920s. Atglen, PA: Schiffer Publishing Ltd., 1996. Print.

Luhrmann, Baz, dir. The Great Gatsby. Writ. F. Scott Fitzgerald, and Dir. Warner Brothers, 2013. Film.

Masteroff, Joseph, Fred Ebb, and John Kander. Cabaret. revised. New York: Tams-Witmark Music Library, Inc., 1967. Print.

Munz, Lori, and Karin Sieber. Cabaret Berlin. Hamburg, Germany: Edel Classics GmbH, 2005. Print.

"Online Archives and Database." The Metropolitan Museum of Art Costume Institute. New York: 20002014. <www.metmuseum.org>.

Remerowski, Ted, and Marrin Canell. Dir. Legendary Sin Cities: Paris, Berlin, Shanghai. Paradigm Pictures, CBC Canada: 2005. Documentary Film

Rennells, Lauren. Retro Makeup: Techniques for Applying the Vintage Look. Denver, CO: HRST Books, 2011. Print.

Rothstein, Natalie.ed. Four Hundred Years of Fashion. Milan, Italy: Victoria \& Albert Museum, 1984. Print. 
Ruhl, Verlag Moritz. Deutsche Uniformen. 2006. Graphic. USM Books, Inc., Leipzig, Germany. Web. $<$ usmbooks.com>.

Salen, Jill. Vintage Lingerie: 30 Patterns Based on Period Garments Plus Finishing Techniques. New York: St. Martin's Press, 2011. Print.

"Sally Rand (1904-1979)." San Francisco, CA: 1995. <http://www.sfmuseum.net/bio/rand.html>.

Tortora, Phyllis G., and Keith Eubank. Survey of Historic Costume. New York: Fairchild Books, 2010. Print.

Ulrich, Barbara. The Hot Girls of Weimar Berlin. Los Angeles, CA: Feral House, 2002. Print.

Von Sternberg, Josef. Dir. The Blue Angel. Writ. Heinrich Mann, Carl Zuckmayer, et. al. Universum Film and Paramount Pictures, 1930. Film. 


\section{INDEX OF FIGURES AND ILLUSTRATIONS}

1. Dix, Otto. 'Grosstadt' (Urban Debauchery). 1927. Painting. Bridgeman Art Library, Staatsgalerie, Stuttgart, Germany. Web.

2. Benedictus, Edouard. Plate 11 from "Nouvelles Variations". 1928. print. The Annex Galleries, Santa Rosa, CA. Web. <http://www.annexgalleries.com/inventory/detail/JEJA193/EdouardBenedictus/Plate-11-from-Nouvelles-Variations>.

3. Chanel, Gabrielle. Three Gowns 1925-1928. Photograph. Arizona Costume Institute, Phoenix . Web. <http://www.arizonacostumeinstitute.com/ACl/ChanelGroup.html>.

4. Silk Party Dress 1925-1926. Photograph. Vintage Textile, New Hampshire. Web. $<w w w . v i n t a g e t e x t i l e . c o m>$.

5. Dix, Otto. Portrait of the Dancer Anita Berber. 1925. Painting. Staatsgalerie, Stuttgart, Germany. Web. $<$ www.artnet.com>.

6. Feather Headdress. 2012. Photograph. All That Jazz Vintage Fashion Blog. Web. $<$ http://alllthatjazz.tumblr.com/>.

7. Beaded Leotard Costume. 2012. Photograph. All That Jazz Vintage Fashion Blog. Web. $<$ http://alllthatjazz.tumblr.com/>.

8. De Bont, Th. J. Starburst Shoe, Dutch, 1922-1925. 2011. Photograph. Bata Shoe Museum, Toronto, Canada. Web. <http://www.batashoemuseum.ca/exhibitions/roaring20s>.

9. Claudette Colbert. 2011. Photograph. All That Jazz Vintage Fashion Blog. Web. $<$ http://alllthatjazz.tumblr.com/>.

10. Silk Crepe Dolman. Gimbel Brothers. Paris. 1926. Laubner, Ellie. Fashions of the Roaring 1920s. Atglen, PA: Schiffer Publishing Ltd., 1996. Print.

11. Velvet and fox fur promenade coat. Atelier Bachroitz. Paris. 1927. Dirix, Emmanuelle, and Charlotte Fiell. Fashion Sourcebook: 1920s. London, England: Fiell Publishing, 2011. Print.

12. Morning Leisure Robe, 1930. Blum, Stella. Everyday Fashions of the Twenties: As Pictured in Sears and Other Catalogs. New York: Dover Publications, 1981. Print.

13. Velour dancing dress, Atelier Bachroitz, Paris, 1927 Dirix, Emmanuelle, and Charlotte Fiell. Fashion Sourcebook: 1920s. London, England: Fiell Publishing, 2011. Print.

14. Colleen Moore, silent film actress and flapper. Colleen Moore, actress, Synthetic Sin. 1929. Photograph. www.coletterie.com. Web.

15. Bernard, Augusta. Velvet and Satin Elongated Line Gown. 1933. Photograph. Vogue Archives, CondeNast, New York. Web. <http://search.proquest.com.www.libproxy.wvu.edu/docview/904315394/flash/1 ?accountid=2837>.

16. De Tirtoff, Romain. Erté Fashion Drawings and Illustrations from "Harper's Bazaar". New York: Dover Publications, 1921. Print.

17. Soeurs, Callot. Brocade Gown. 1928. Photograph. Goldstein Museum of Design, St. Paul, MN. Web.

18. Eberth, Atelier. Morphine (Anita Berber and Sebastian Droste). 1920. Photograph. Berliner Illusrierte Zeitung, Berlin. Web. 
19. Early 1930s Men's Fashion Illustration. 2012. Graphic. Art Deco Society of California, San Francisco, CA. Web.

20. The German Student. 1936. Nazi Propaganda Poster. United States Holocaust Memorial Museum, Washington DC. Web.

21. Blum, Stella. Everyday Fashions of the Twenties: As Pictured in Sears and Other Catalogs. New York: Dover Publications, 1981. Print.

22. Blum, Stella. Everyday Fashions of the Twenties: As Pictured in Sears and Other Catalogs. New York: Dover Publications, 1981. Print.

23. Blum, Stella. Everyday Fashions of the Twenties: As Pictured in Sears and Other Catalogs. New York: Dover Publications, 1981. Print.

24. Preston, John. "The Dreyfus Affair by Piers Paul Read: Review."Telegraph. (2012): Web. $<$ http://www.telegraph.co.uk/>.

25. Marlene Dietrich Collection Berlin. 1931. Photograph. Deutsche Kinemathek - Museum für Film und Fernsehen, Berlin. Web. <www.marlenedietrich.org >.

26. Sheer Silk Negligee 1927-1930. Photograph. Vintage Textile, New Hampshire. Web. $<w w w . v i n t a g e t e x t i l e . c o m>$.

27. Salen, Jill. "Girdle, 1932." Vintage Lingerie: 30 Patterns Based on Period Garments Plus Finishing Techniques. New York: St. Martin's Press, 2011. Print.

28. Blum, Stella. Everyday Fashions of the Twenties: As Pictured in Sears and Other Catalogs. New York: Dover Publications, 1981. Print.

29. Silk Bra and Tap Panty Set. 1930. Photograph. The Metropolitan Museum of Art Costume Institute, New York. Web.

30. Fabrizio, Ashleigh. Myrna Loy: One of the Brightest Stars. 2012. Photograph. Reel Hollywood Legends Blog. Web.

31. Flapper Makeup Fashion Editorials. 2012. Photograph All That Jazz Vintage Fashion Blog. Web. $<$ http://alllthatjazz.tumblr.com/>.

32. Flapper Makeup Fashion Editorials. 2012. Photograph All That Jazz Vintage Fashion Blog. Web. $<$ http://alllthatjazz.tumblr.com/>.

33. Boyle, John W. Betty Blythe in Queen of Sheba. 1921. Photograph. Fox Film Company, California. Web.

34. Erté. Illustration for Harper's Bazaar. 1918. Drawing. Harper's Bazaar, New York. Print.

35. Faith Bacon, Ziegfeld Follies Girl (1928-1931).2012. Photograph. All That Jazz Vintage Fashion Blog. Web. <http://allthatjazz.tumblr.com/>.

36. Ulrich, Barbara. The Hot Girls of Weimar Berlin. Los Angeles, CA: Feral House, 2002. Print.

37. "Al Capone and Prohibition." 2014. The History Channel website. <www.history.com/photos/alcapone-and-prohibition. 
38. Ruhl, Verlag Moritz. Deutsche Uniformen. 2006. Graphic. USM Books, Inc., Leipzig, Germany. Web. $<$ usmbooks.com>.

39. Three Sailor Chums, 1920s. 2011. Photograph. Ipernity, United Kingdom. Web.

40. Blum, Stella. Everyday Fashions of the Twenties: As Pictured in Sears and Other Catalogs. New York: Dover Publications, 1981. Print.

41. Pavlov, Fyodor. Two Illustrations. Painting. Fyodor Pavlov Portfolio, New York. Web.

$<$ http://www.baritaria.com/>.

42. Caldwell Day, Candice. Silk Stretcher Frame with Habotai Silk. 2013. Photograph. West Virginia University School of Theatre and Dance, Morgantown, WV. Digital Image.

43. Caldwell Day, Candice. Back Detail of Finished Kimono for Sally Bowles. 2013. Photograph. West Virginia University School of Theatre and Dance, Morgantown, WV. Digital Image.

44. Neuenschwander, Stephen. Sally Bowles Wearing Kimono in Cabaret Production. 2013.

Photograph. West Virginia University School of Theatre and Dance, Morgantown, WV. Digital Image.

45. Caldwell Day, Candice. Mint Green Dress in Process for Actress Sara Gianola. 2013. Photograph. West Virginia University School of Theatre and Dance, Morgantown, WV. Digital Image.

46. Caldwell Day, Candice. Nazi Burlesque Kickline Leotards. 2013. Photograph. West Virginia University School of Theatre and Dance, Morgantown, WV. Digital Image.

47. Caldwell Day, Candice. Plaster Mold and Liquid Neoprene Cast Disks. 2013. Photograph. West Virginia University School of Theatre and Dance, Morgantown, WV. Digital Image.

48. Caldwell Day, Candice. Kit Kat Girl Headpiece for "Money" Song. 2013. Photograph. West Virginia University School of Theatre and Dance, Morgantown, WV. Digital Image.

49. Caldwell Day, Candice. Gold Gown for Sally Bowles. 2013. Photograph. West Virginia University School of Theatre and Dance, Morgantown, WV. Digital Image.

50. Caldwell Day, Candice. Sequin Detail on Gold Gown. 2013. Photograph. West Virginia University School of Theatre and Dance, Morgantown, WV. Digital Image.

51. Caldwell Day, Candice. Erté Tiara for Sally Bowles. 2013. Photograph. West Virginia University School of Theatre and Dance, Morgantown, WV. Digital Image.

52. Actor Mark Combs as Nazi Supporter Ernst Ludwig. 2013. Photograph. West Virginia University School of Theatre and Dance, Morgantown, WV. Digital Image.

53. Neuenschwander, Stephen. Vincent Pelligrino as The Emcee in Baby New Year Costume. 2013. Photograph. West Virginia University School of Theatre and Dance, Morgantown, WV. Digital Image.

54. Neuenschwander, Stephen. Gorilla Girl and The Emcee. 2013. Photograph. West Virginia University School of Theatre and Dance, Morgantown, WV. Digital Image.

55. Neuenschwander, Stephen. Tomorrow Belongs to Me. 2013. Photograph. West Virginia University School of Theatre and Dance, Morgantown, WV. Digital Image. 


\section{PHOTO AND IMAGE CREDITS}

Costume process photos taken by the Cabaret production's Costume Designer Candice Caldwell Day.

Cabaret production photos taken by West Virginia University School of Theatre and Dance's Technical Director Steven Neuenschwander and West Virginia University photography. 


\section{APPENDIX I: CABARET COSTUME TRACK}

*(Items in red indicate quick-changes or important wardrobe and dresser notes)

2013

CABARET

SKETCH LIST \& COSTUME TRACK

Designer: C. Day

Version 3.0

\begin{tabular}{|c|c|c|c|c|}
\hline $\begin{array}{l}\text { Sk. } \\
\text { No. }\end{array}$ & Character & Actor & Costume Description & Act/Scenes \\
\hline 1 & Sally & Nora Perone & Silk painted robe, (underdress blue leotard) & ONE/ 1 \\
\hline 2 & Sally & & Blue \& Black Fringe Leotard & ONE/ 4 \\
\hline \multirow[t]{2}{*}{3} & Sally & & Teal Dress, Fur coat, Hat & ONE/ 5,9 \\
\hline & Sally & & Fur Coat over Purple Velvet dress & ONE/ 11 \\
\hline \multirow[t]{2}{*}{4} & Sally & & Purple Velvet Party Dress & ONE/ 12 \\
\hline & Sally & & Silk Painted Robe ${ }^{*}$ (underdress Teal Dress) & TWO/ 4 \\
\hline \multirow[t]{3}{*}{5} & Sally & & Gold \& Black gown \& tiara (2 part QuickChange) & TWO/ 5 \\
\hline & Sally & & Teal Dress, HeadScarf\& Purse, (No Coat) & TWO/ 6 \\
\hline & Sally & & Silk Painted Robe & TWO/ 7 \\
\hline \multirow[t]{2}{*}{6} & Cliff & Bryan Staggers & Suit, Hat \& Overcoat & ONE/ 2 \\
\hline & Cliff & & Suit Only (hold hat \& coat?) & ONE/ 3,4 \\
\hline \multirow[t]{6}{*}{7} & Cliff & & Sweater Vest \& Tie & ONE/ 5,9 \\
\hline & Cliff & & Suit & ONE/ 12 \\
\hline & Cliff & & Suit, enter in Hat \& Coat & TWO/ 4 \\
\hline & Cliff & & Suit & TWO/ 5 \\
\hline & Cliff & & Shirt, Tie \& Vest *(Black Eye) & TWO/ 6 \\
\hline & Cliff & & Suit, Hat \& Overcoat *( Black Eye) & TWO/ 7 \\
\hline \multirow[t]{2}{*}{8} & Emcee & V. Pelligrino & Corset, Pants, Bowler, Boots, Tie, Suspenders & ONE/ 1,2 \\
\hline & Emcee & & Basic Corset Look & ONE/ 4 \\
\hline \multirow[t]{4}{*}{9} & Emcee & & New Years Old Man / Baby & ONE/ 4 \\
\hline & Emcee & & KIMONO over Basic Corset Look & ONE / 4 \\
\hline & Emcee & & Basic Corset, add FEATHER BOA - 2 Ladies & ONE/ 6 \\
\hline & Emcee & & Basic Corset Outfit (Hitler Mustache?) & ONE/ 8 \\
\hline 10 & Emcee & & "Money" Jacket, Top Hat, Bow Tie, (over corset) & ONE/ 10 \\
\hline $8 a$. & Emcee & & Overcoat \& Fedora (over corset outfit) & ONE/ 12 \\
\hline \multirow[t]{2}{*}{11} & Emcee & & Nazi Girl, gloves, wig, boot covers & TWO/ 1 \\
\hline & Emcee & & Basic Corset Outfit & TWO/ 3, 4, 5, 7 \\
\hline 12 & F. Schneider & Brianne Taylor & Pink House Robe & ONE/ 3 \\
\hline \multirow[t]{2}{*}{13} & F. Schneider & & Burgundy Day Dress & ONE/ 5,7 \\
\hline & F. Schneider & & Pink House Robe & ONE/ 11 \\
\hline \multirow[t]{3}{*}{14} & F. Schneider & & Cream Party Suit & ONE/ 12 \\
\hline & F. Schneider & & Burgundy Dress, Overcoat, Purse, Gloves & TWO/ 2 \\
\hline & F. Schneider & & Burgundy Day Dress & TWO/ 4, 7 \\
\hline
\end{tabular}




\begin{tabular}{|c|c|c|c|c|}
\hline 15 & Herr Schultz & Beau Harris & Gray Suit \& Bowtie & ONE/ 3,7 \\
\hline & Herr Schultz & & Vest /Shirt \& Bowtie & ONE/ 11 \\
\hline & Herr Schultz & & Full Suit & ONE/ 12 \\
\hline & Herr Schultz & & Shop Apron over shirt, vest \& bow tie & TWO/ 2 \\
\hline & Herr Schultz & & Full Suit, Hat, Overcoat (no hat/coat in Finale) & TWO/ 6, 7 \\
\hline Sk.\# & Character & Actor & Costume Description & Act/Scenes \\
\hline 16 & Fraulein Kost & M. Dransfield & Lingerie Only-- Kit Kat & ONE/ 1, \\
\hline \multirow[t]{6}{*}{ 16a. } & Kost & & Lingerie \& Robe & ONE/ 3 \\
\hline & Kost & & Lingerie Only-- Kit Kat & ONE/ 4,6 \\
\hline & Kost & & Lingerie \& Robe & ONE/ 7 \\
\hline & Kost & & OVERCOAT for end of scene & ONE/ 7 \\
\hline & Kost & & MONEY song-- Lingerie \& accessories & ONE/ 10 \\
\hline & Kost & & Lingerie \& Robe & ONE/ 11 \\
\hline \multirow[t]{3}{*}{17} & Kost & & Red Party Dress \& Scarf & ONE/ 12 \\
\hline & Kost & & Lingerie Only-- Kit Kat & TWO/ 5 \\
\hline & Kost & & Lingerie \& Robe & TWO/ 7 \\
\hline \multirow[t]{7}{*}{18} & Ernst & Mark Combs & Blue Pinstripe Suit & \\
\hline & Ernst & & Suit, Hat, Trenchcoat & ONE/ 2 \\
\hline & Ernst & & Suit only & $\mathrm{ONE} / 4,5$ \\
\hline & Ernst & & Enter in Hat--take off & ONE/ 9 \\
\hline & Ernst & & $\begin{array}{l}\text { Hat \& Trench, take off @ pg. } 59 * \text { ARMBAND on } \\
\text { suit }\end{array}$ & ONE/ 12 \\
\hline & Ernst & & Suit \&NAZI ARMBAND & TWO/ 5 \\
\hline & Ernst & & Suit \&NAZI ARMBAND & TWO/ 7 \\
\hline 19 & Max & Ben Forer & & \\
\hline \multirow[t]{6}{*}{ 19a } & Customs Officer & & Blue Uniform Coat, Hat, mustache & ONE/ 2 \\
\hline & Max & & Charcoal \& Purple gangster suit \& Fedora & ONE/ $3,4,6,8,10,12$ \\
\hline & Max & & *ONE/ 8 ONLY - Add NAZI ARMBAND & \\
\hline & Max & & Charcoal suit, Fedora NAZI ARMBAND Sc. 5 & TWO/ 4, 5 \\
\hline & Customs Officer & & Blue Uniform Coat, Hat, mustache & TWO/ 7 \\
\hline & Max & & Charcoal suit, Fedora NAZI ARMBAND & TWO/ 7 \\
\hline \multirow[t]{3}{*}{20} & $\begin{array}{l}\text { KIT KAT GIRLS - } \\
6\end{array}$ & & Lingerie Basic Look + Accessories & ONE/ $1,4,6$ \\
\hline & (7 with Maggie) & & Lexi Smith, Megan Sydner, Sara Gianola, & \\
\hline & & & Marissa Kulp, Jocelyn Raychel, Leonor Cortez & \\
\hline 21 & $\begin{array}{l}\text { KIT KAT GIRLS - } \\
2\end{array}$ & Adam \& Megan & TWO LADIES- Babydoll\& Turban ( ${ }^{*}$ girl \& BOY) & ONE/ 6 \\
\hline 22 & KIT KAT GIRLS- & incl. Maggie & MONEY - gloves, headpiece w/ Basic Lingerie & ONE/ 10 \\
\hline
\end{tabular}




\begin{tabular}{|c|c|c|c|c|}
\hline & 7 & & & \\
\hline & & & *remove arm drape beads after sitting pretty & \\
\hline 23 & $\begin{array}{l}\text { KIT KAT GIRLS- } \\
6\end{array}$ & & Party Dresses \& Accessories & ONE/ 12 \\
\hline 24 & $\begin{array}{l}\text { KIT KAT GIRLS- } \\
5\end{array}$ & $\begin{array}{l}\text { (NO Maggie, } \\
\text { Sara) }\end{array}$ & Nazi Girls & TWO/ 1 \\
\hline 25 & $\begin{array}{l}\text { KIT KAT GIRLS- } \\
1\end{array}$ & Leonor & GORILLA girl--- 1 person & TWO/ 3 \\
\hline & $\begin{array}{l}\text { KIT KAT GIRLS - } \\
6\end{array}$ & & Basic Lingerie Look - ALL 6 girls & TWO/ 5 \\
\hline & $\begin{array}{l}\text { KIT KAT GIRLS- } \\
3\end{array}$ & & Basic Lingerie Look - 4 GIRLS (not Marissa, Sara) & TWO/ 7 \\
\hline 26 & $\begin{array}{l}\text { KIT KAT GIRLS- } \\
3\end{array}$ & Marissa, Sara G & Concentration Camp Prisoner- 2 GIRLS & TWO/ 7 \\
\hline & & & NO WIG, Pincurls Under BERET HAT, BAREFOOT & \\
\hline Sk. \# & Character & Actor & Costume Description & Act/Scenes \\
\hline 27 & $\begin{array}{l}\text { KIT KAT BOYS - } \\
3\end{array}$ & $\begin{array}{l}\text { Adam, Demiah, } \\
\text { Cody }\end{array}$ & Striped Vest \& Pants Basic Look & ONE/ $1,3,4,6,8$ \\
\hline & KAT BOYS & ADAM ONLY & TWO LADIES pink dress \& accessories & ONE/6 \\
\hline & KIT KAT BOYS- 3 & All 3 & MONEY - Add Epaulets, Bowlers, Necklace & ONE/ 10 \\
\hline & & DEMIAH & Overcoat + hat, remove/replace bowler & \\
\hline 28 & KIT KAT BOYS- 3 & All 3 & Party: Shirt, Pants, Vests, Cap, Tie & ONE/ 12 \\
\hline & KAT BOYS & ADAM ONLY & Nazi Girl & TWO/ 1 \\
\hline & KAT BOYS & All 3 & Striped Vest \& Pants Basic Look & TWO/ 5 \\
\hline 29 & KIT KAT BOYS- 3 & All 3 & Concntrn. Camp Prisoner- BAREFOOT & TWO/ 7 \\
\hline 30 & $\begin{array}{l}\text { KIT KAT BAND- } \\
4\end{array}$ & Jamie, Karen & Black \& Gold Dress. Kitty Hat, Cuffs, Tail & ONE/ $1,4,6,10,12$ \\
\hline & $\begin{array}{l}\text { KIT KAT BAND- } \\
4\end{array}$ & Yana, Anne & Dress \& Kitty accessories-- *Entire Show* & TWO/ 3, 5, 7 \\
\hline
\end{tabular}

\begin{tabular}{|c|c|c|c|c|}
\hline 31 & Young Girl One & Ashley Koon & Purple Dress $\&$ accessories & ONE/ $1,3,4,6$ \\
\hline \multirow[t]{2}{*}{$31 a$} & Little Nazi Child & & Nazi Propaganda Girl & ONE/ 8 \\
\hline & & & Purple Dress \& Accessories & ONE/ 10, TWO/ 5,7 \\
\hline \multirow[t]{2}{*}{32} & Young Girl Two & H. Redmond & Green Blouse \& Brown Plaid Skirt, accessories & ONE/ $1,3,4,6,10$ \\
\hline & Telephone Girl & & & TWO/ 3, 5,7 \\
\hline \multirow[t]{2}{*}{33} & Older Woman & F. Snyderman & Dress, Overcoat, Furs, Hat & ONE/ $1,3,4,6,10$ \\
\hline & & & & TWO/ 3, 5,7 \\
\hline & & & & \\
\hline & & & & \\
\hline
\end{tabular}




\begin{tabular}{|c|c|c|c|c|}
\hline & MAN 1 & Isaac Snyder & & \\
\hline 34 & Sailor & & Blue Uniform suit and hat & ONE/ $1,4,6,8$ \\
\hline \multirow[t]{3}{*}{35} & Guest/Man & & suit, hat & ONE/ 10 \\
\hline & Sailor & & Blue Uniform suit and hat & $\begin{array}{l}\text { ONE/11, } 12 \text { TWO/ 5, } \\
7\end{array}$ \\
\hline & MAN 2 & Matt Feldman & & \\
\hline 36 & Sailor & & Blue Uniform suit \& hat & ONE/ $1,3,4$ \\
\hline \multirow[t]{6}{*}{37} & Guest/Man & & 3 piece suit $\&$ hat & ONE/ 6,8 \\
\hline & Guest/Man & & (ONE/8- NAZI armband) & ONE/ 8 \\
\hline & Sailor & & Blue Uniform suit \& hat & ONE/ 10, 11 \\
\hline & Guest/Man & & 3 piece suit NO Armband & ONE/ 12, TWO/ 2 \\
\hline & Guest/Man & & ( with NAZI armband) & TWO/ 5, 7 \\
\hline & MAN 3 & Dallas Wright & & \\
\hline 39 & Sailor & & Blue Uniform Suit \& Hat & ONE/ $1,4,6,7$ \\
\hline \multirow[t]{3}{*}{40} & Nazi Guard & & Nazi Uniform & ONE/ 8 \\
\hline & Sailor & & Blue Uniform Suit \& Hat & ONE/ $10,11,12$ \\
\hline & Guest/Man & & Suit, Tie \& Hat NO ARMBAND & TWO/ 2 \\
\hline \multirow[t]{2}{*}{41} & Nazi Guard & & Nazi Uniform & TWO/ 5, 7 \\
\hline & Character & Actor & Costume Description & Act/Scenes \\
\hline \multirow[t]{2}{*}{ Sk. \# } & MAN 4 & Joe Ryan & & \\
\hline & Guest/ Man & & Stock Suit \& Hat & ONE/ 1 \\
\hline \multirow[t]{2}{*}{42} & Guest/Man & & Stock Suit \& Hat & ONE/ 4,6 \\
\hline & Nazi Guard & & Nazi Uniform & ONE/ 8 \\
\hline \multirow[t]{3}{*}{43} & Guest/Man & & Stock Suit \& Hat & ONE/ 10, TWO/2 \\
\hline & Nazi Guard & & Nazi Uniform & TWO/ 5, 7 \\
\hline & Character & Actor & Costume Description & Act/Scenes \\
\hline \multirow[t]{2}{*}{ Sk. \# } & MAN 5 & $\begin{array}{l}\text { Brendan } \\
\text { Sheehan }\end{array}$ & & \\
\hline & $\begin{array}{l}\text { Guest/ Taxi } \\
\text { Man }\end{array}$ & & Coat, Cap, Knickers, Argyle Socks Outfit & ONE/ 1,4 \\
\hline \multirow[t]{2}{*}{44} & Taxi Driver & & Coat, Cap, Knickers, Argyle Socks Outfit & ONE/ 5 \\
\hline & Nazi Guard & & Nazi Uniform & ONE/ 8 \\
\hline \multirow[t]{2}{*}{45} & $\begin{array}{l}\text { Guest/ Taxi } \\
\text { Man }\end{array}$ & & Coat, Cap, Knickers, Argyle Socks Outfit & ONE/ 10, TWO/ 3 \\
\hline & Nazi Guard & & Nazi Uniform & TWO/ 5, 7 \\
\hline & & & & \\
\hline
\end{tabular}




\begin{tabular}{|r|l|l|l|l|} 
& Woman 1 & N. Ciampa & Suit \& Overcoat, Hat & Entire Show* \\
\hline 46 & & & & \\
\hline 47 & Woman 2 & J. Donahue & Suit \& Overcoat, Hat, Boots & Entire Show* \\
\hline & & & & \\
& Maitre'D & $\begin{array}{l}\text { Willa } \\
\text { McWhorter }\end{array}$ & Men's Tuxedo & Entire Show* \\
\hline
\end{tabular}


APPENDIX II: COSTUME PIECE LIST SAMPLE

\begin{tabular}{|l|l|l|l|l|l|}
\hline WVU & $\begin{array}{l}\text { CABARET } \\
2013\end{array}$ & COSTUME PIECE LIST & & Designer: & $\begin{array}{l}\text { Candice } \\
\text { Caldwell Day }\end{array}$ \\
\hline & & & & & \\
\hline Actor & Character & Costume Item & Shoes & Wigs & Hats \\
\hline
\end{tabular}

Nora

Perone Sally Bowles

\begin{tabular}{|c|c|c|c|}
\hline \multirow{2}{*}{\multicolumn{4}{|c|}{$\begin{array}{l}\text { Blue Leotard } \\
\text { Fishnet Arm Warmers }\end{array}$}} \\
\hline & & & \\
\hline \multicolumn{4}{|l|}{ Black Necklace } \\
\hline \multicolumn{4}{|l|}{ Blue Feather Headband } \\
\hline \multicolumn{4}{|l|}{ Nude Spanx\& Leotard } \\
\hline \multicolumn{4}{|l|}{ Thigh High Hose (Black \& } \\
\hline \multicolumn{4}{|l|}{ Fishnet) } \\
\hline \multicolumn{4}{|l|}{ Silicone Bra Cups } \\
\hline \multicolumn{4}{|l|}{ Black Bracelets } \\
\hline Teal Day Dress & Black Character & & Brown Cloche \\
\hline \multicolumn{4}{|l|}{ Black \& gold Fur Coat } \\
\hline \multicolumn{4}{|l|}{ Brown Cloche Hat } \\
\hline \multicolumn{4}{|l|}{ Mauve Head Scarf } \\
\hline \multicolumn{4}{|l|}{ Fringe Purse } \\
\hline & Copper Shoe & & \\
\hline Purple Velvet Dress & Clips & & Gold Headband \\
\hline \multicolumn{4}{|l|}{ Purple Earrings } \\
\hline \multicolumn{4}{|l|}{ Gold Sequin, White } \\
\hline \multicolumn{4}{|l|}{ Feather Headband } \\
\hline \multicolumn{4}{|l|}{ Butterfly Kimono } \\
\hline Gold Erte Gown & & & Gold Tiara \\
\hline \multicolumn{4}{|l|}{ Black Arm Swag } \\
\hline \multicolumn{4}{|l|}{ Gold Tiara } \\
\hline Gold Bracelet & & & \\
\hline
\end{tabular}




\section{APPENDIX III: DIRECTOR BLAIR'S CAST MATRIX SPREADSHEET}

*(Long horizontal format, minor characters at right side have been cropped)

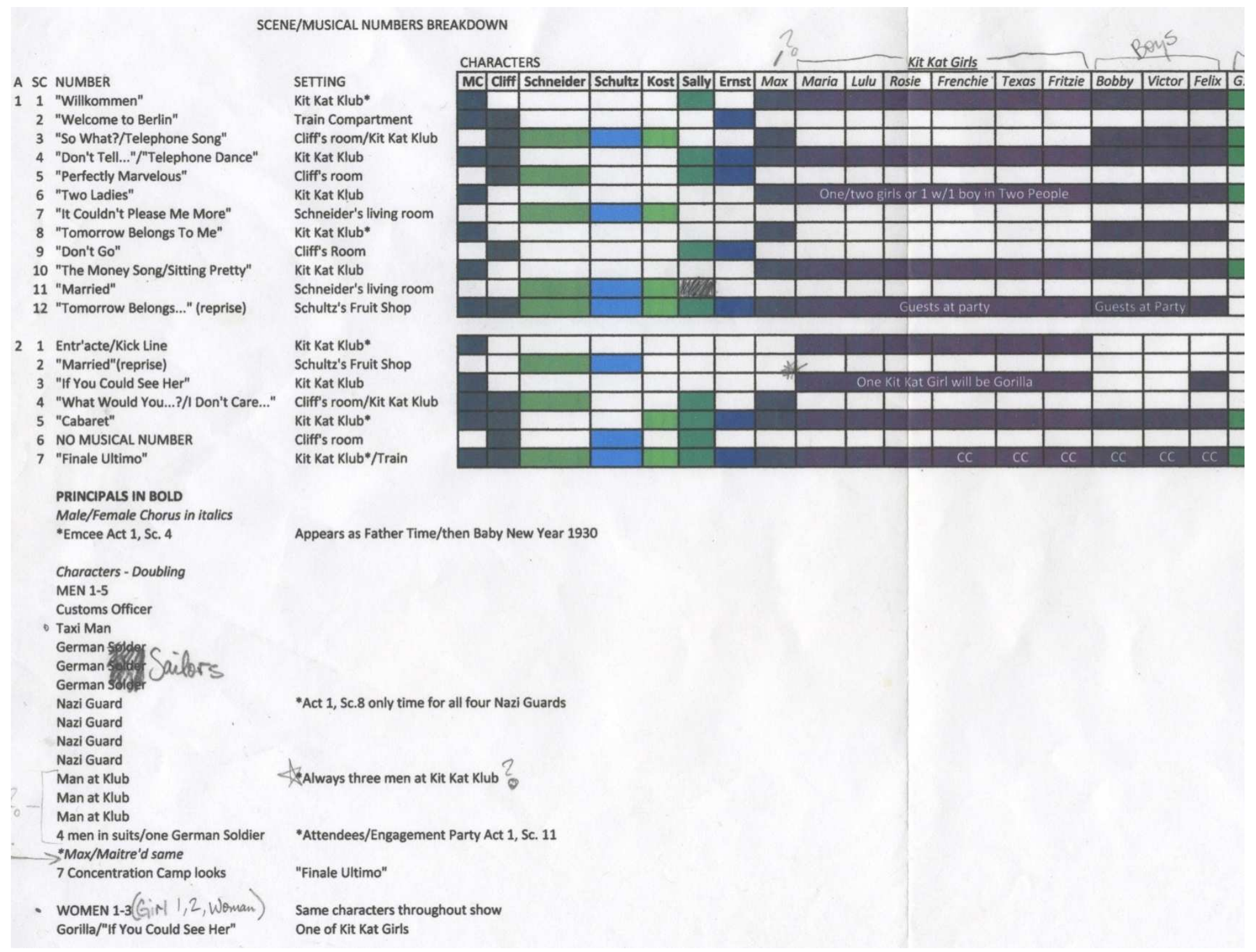


APPENDIX IV: EARLY BUDGET PROJECTION WORKSHEET SAMPLE

\begin{tabular}{|c|c|c|c|c|c|}
\hline CABARET & WVU 2013 & Designer: Candice Day & & & \\
\hline $\begin{array}{l}\text { Costume } \\
\text { Budget }\end{array}$ & Generic Items & & & & \\
\hline Character & Costume Piece & Source/ Notes & Unit Cost & Shipping & Total $\$$ \\
\hline \multirow[t]{18}{*}{ All } & Paint & & 100 & & 100 \\
\hline & Dye & & 120 & & 120 \\
\hline & Dry Cleaning & & 300 & & 300 \\
\hline & $\begin{array}{l}\text { Cheap Pre- } \\
\text { styled Wigs }\end{array}$ & 19 wigs & 177.1 & & 177.1 \\
\hline & General Fabric & 800 - 900 projected estimate & 900 & & 900 \\
\hline & Shipping & estimate $350-450 ?$ & & & 400 \\
\hline & Feathers \& Trim & $\begin{array}{l}\text { estimate } 320-350 ? \text { ( } \$ \$ \$ \text { more if } \\
\text { building fans) }\end{array}$ & 330 & & 330 \\
\hline & $\begin{array}{l}\text { Chef } \\
\text { Jackets/Coats }\end{array}$ & $\begin{array}{l}\text { Happy chef: Nazi men/women, } \\
\text { camp victims }\end{array}$ & 325 & & 325 \\
\hline & Sailor Uniforms & Sailor Uniforms and white hats & & & 95 \\
\hline & Nazi Girls & $\begin{array}{l}\text { Nazi Girls (too much? no monokini- } \\
\text { make with elastic?) }\end{array}$ & & & 465 \\
\hline & Cabaret Girls & $\begin{array}{l}\text { Cabaret Girls Lingerie--- can trim by } \\
\text { buying cheaper? }\end{array}$ & & & 500 \\
\hline & Male Nazi & Four Men & & & 302 \\
\hline & $\mathrm{MC}$ & Boots & & & 50 \\
\hline & Thrifting & cheaper underwear? & & & 250 \\
\hline & Rentals? & $\begin{array}{l}\text { Hopefully borrow all? -- } \\
\text { Fairmont/Ole Miss }\end{array}$ & & & \\
\hline & $\begin{array}{l}\text { Misc / } \\
\text { Contingency }\end{array}$ & & & & 500 \\
\hline & & & & TOTAL & 4814.1 \\
\hline & $\begin{array}{l}\text { COSTUME } \\
\text { BUDGET }\end{array}$ & Purchase Breakdown & & & \\
\hline Character & Costume Piece & Source & Unit Price & Shipping & Total \\
\hline \multirow[t]{9}{*}{ Sally } & WIG-- dark red & Wig America & 22.00? & & \\
\hline & Shoes & pull and paint/alter? & & & \\
\hline & Blue Flapper & & & & \\
\hline & $\begin{array}{l}\text { Blue velvet leo } \\
\text { base }\end{array}$ & $\begin{array}{l}\text { www.dancewearsolutions.com/V367. } \\
\text { aspx }\end{array}$ & 17.95 & & 17.95 \\
\hline & & backup leo-- not velvet, $\$ 18$ & & & \\
\hline & $\begin{array}{l}\text { black lazer } \\
\text { fringe }\end{array}$ & PULLED & & & \\
\hline & $\begin{array}{l}\text { Ostrich Feathers } \\
\text {-headband }\end{array}$ & 4 royal blue 2 navy $\$ 1.90 /$ piece & $1.9(11.90)$ & & \\
\hline & $\begin{array}{l}\text { Coque Feather } \\
\text { Strip 14" }\end{array}$ & 1 Royal Blue & 13.5 & & \\
\hline & $\begin{array}{l}\text { Black beads for } \\
\text { necklace }\end{array}$ & Michaels & 10 & & 10 \\
\hline
\end{tabular}




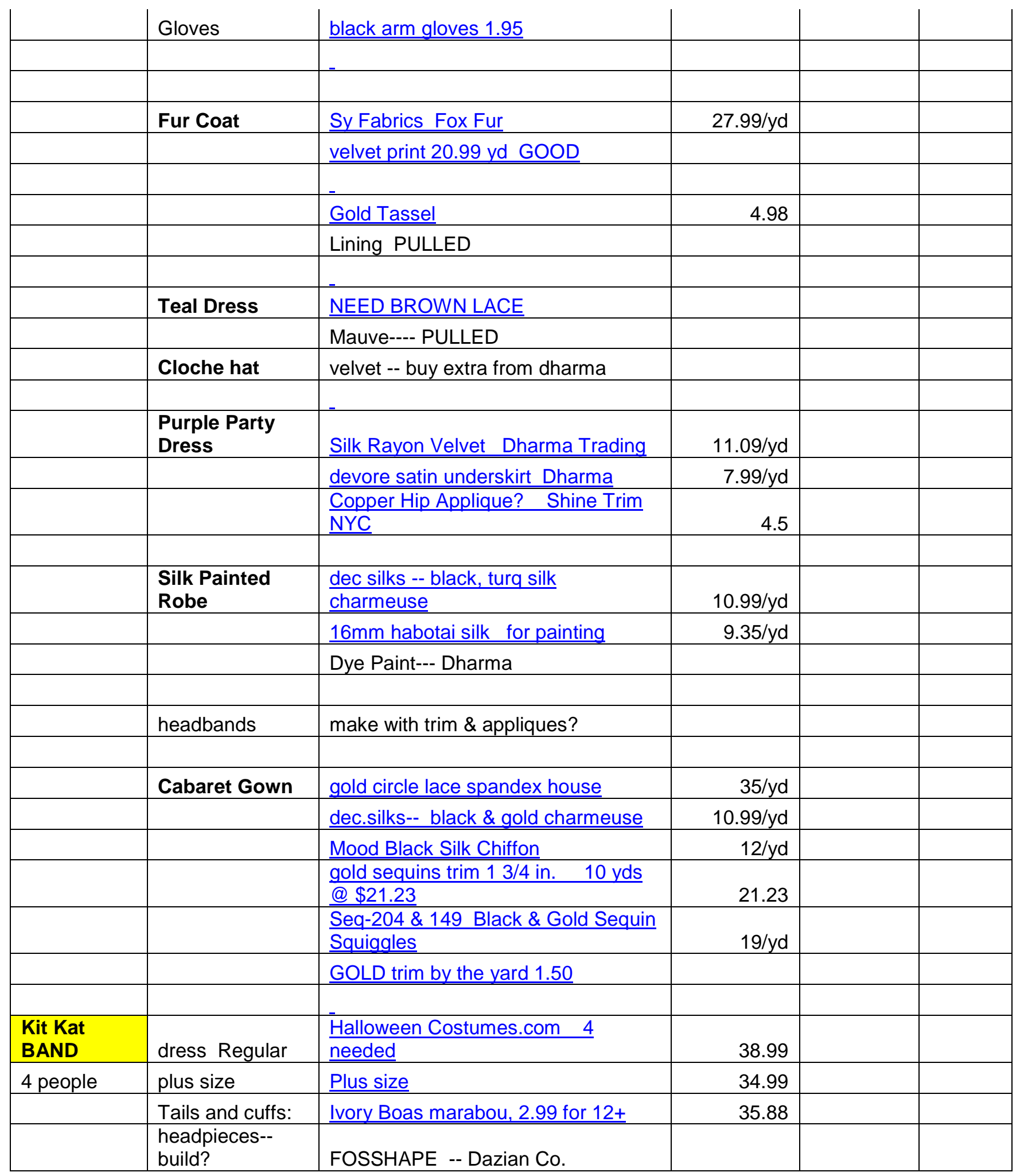


59

APPENDIX V: MAKEUP DESIGN SHEET SAMPLE

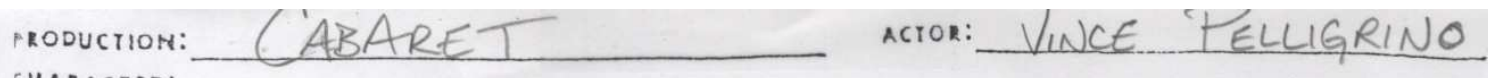
charrotiR: EMCEE

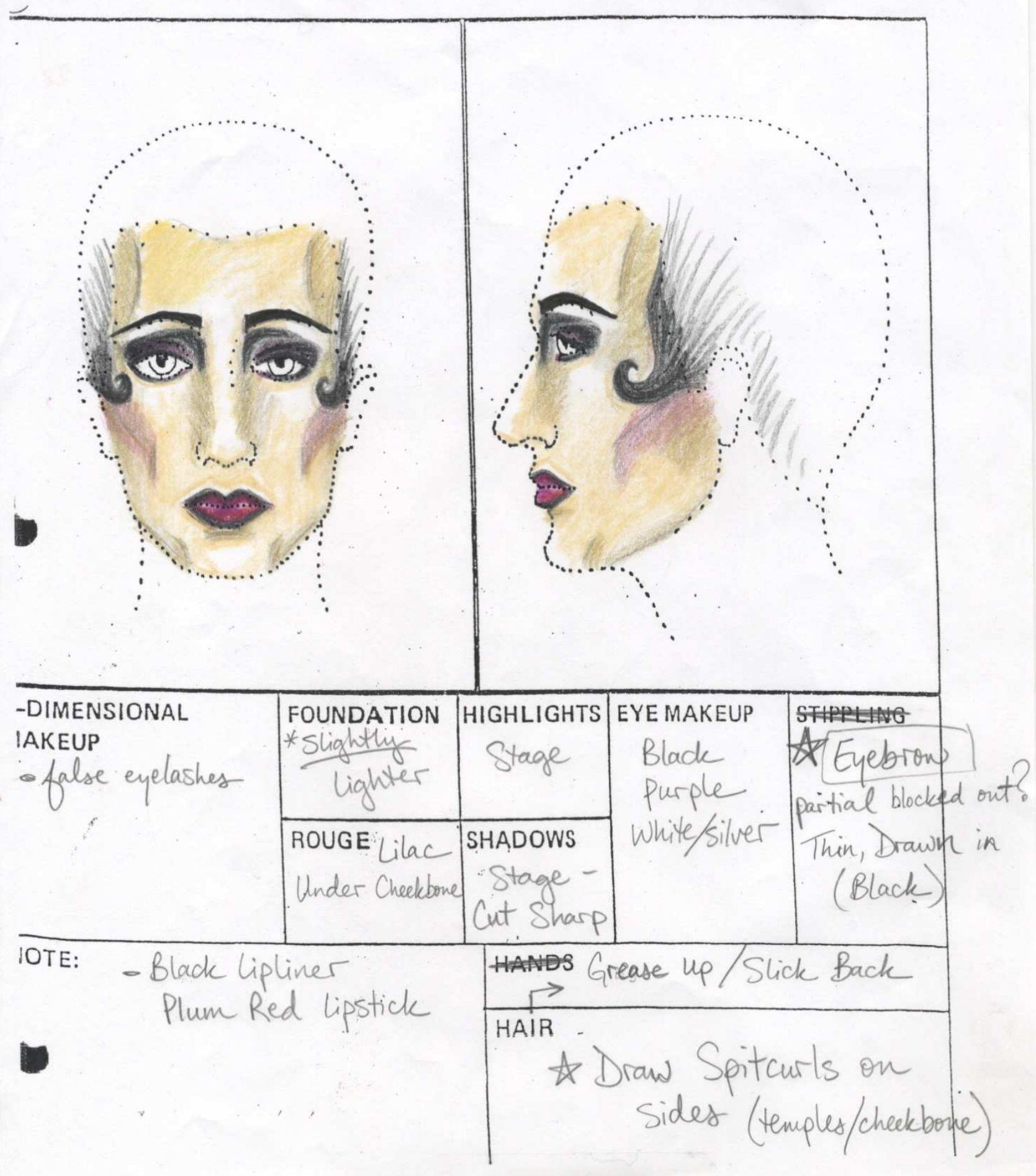


APPENDIX VI: SELECTED COSTUME RENDERINGS AND PRODUCTION PHOTOS

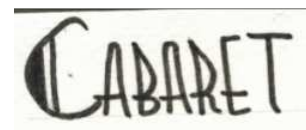

EMCEE
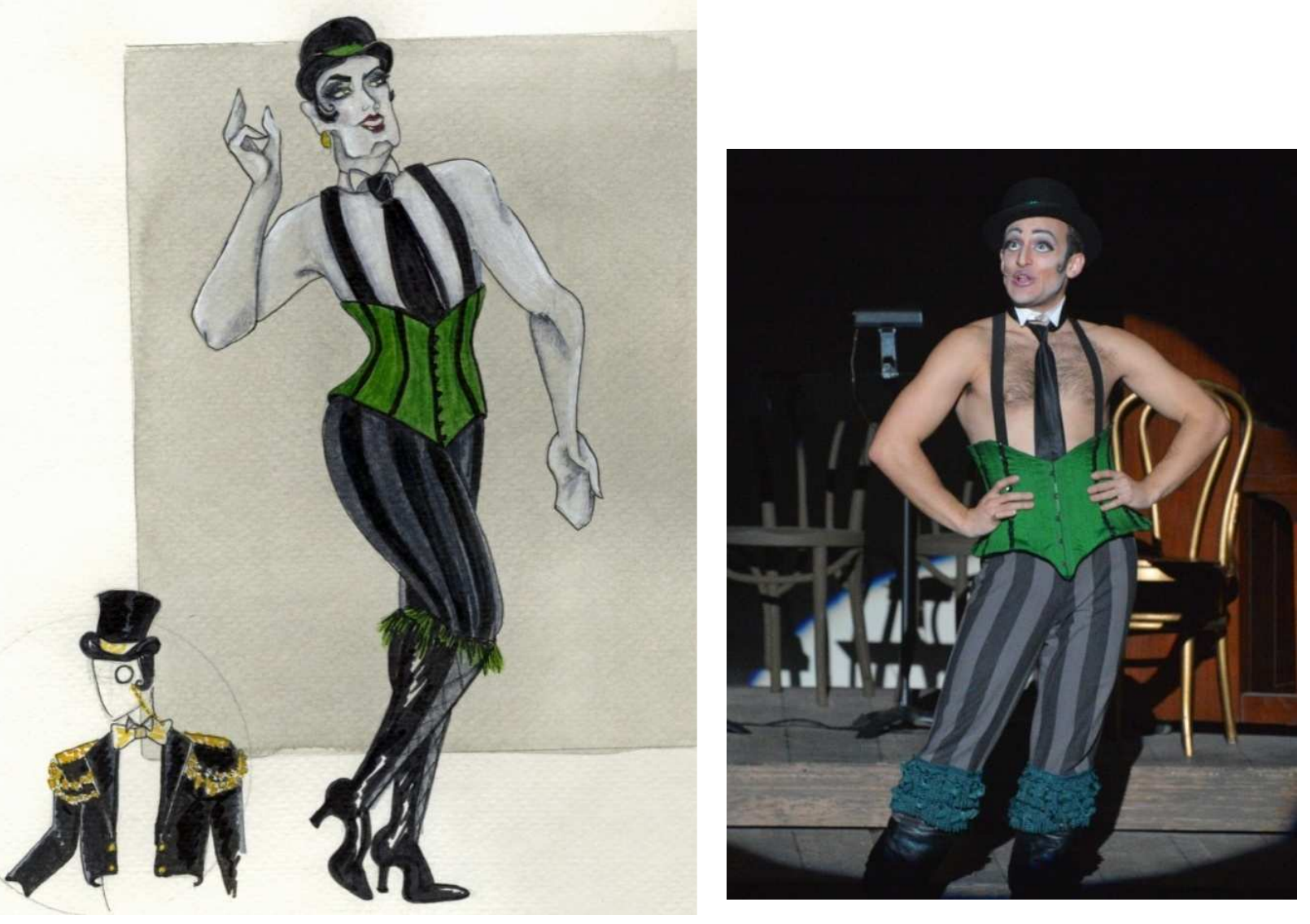


\section{CabHRET}

Saly Bowles
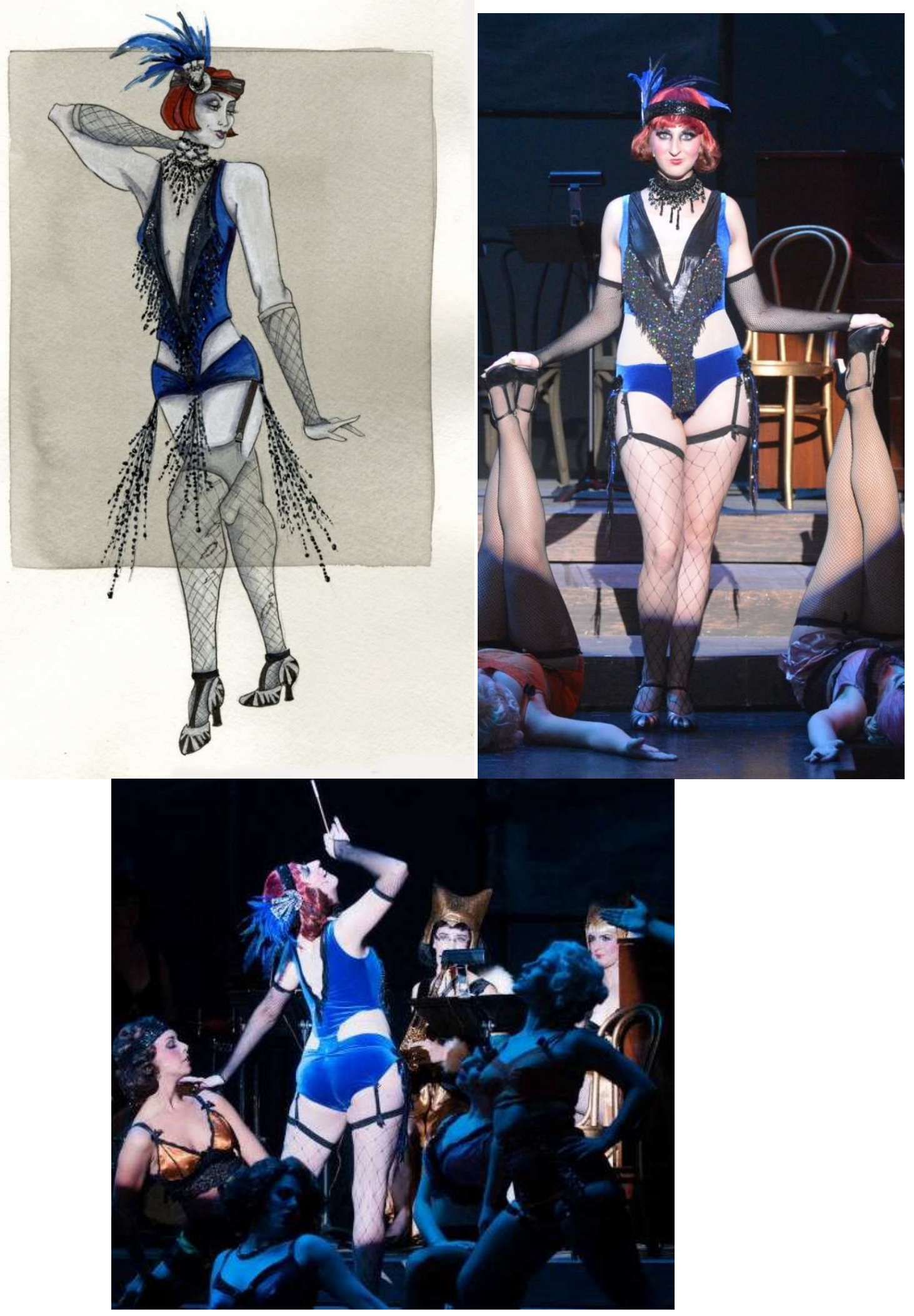


\section{CABARET}

SaLy Bowles

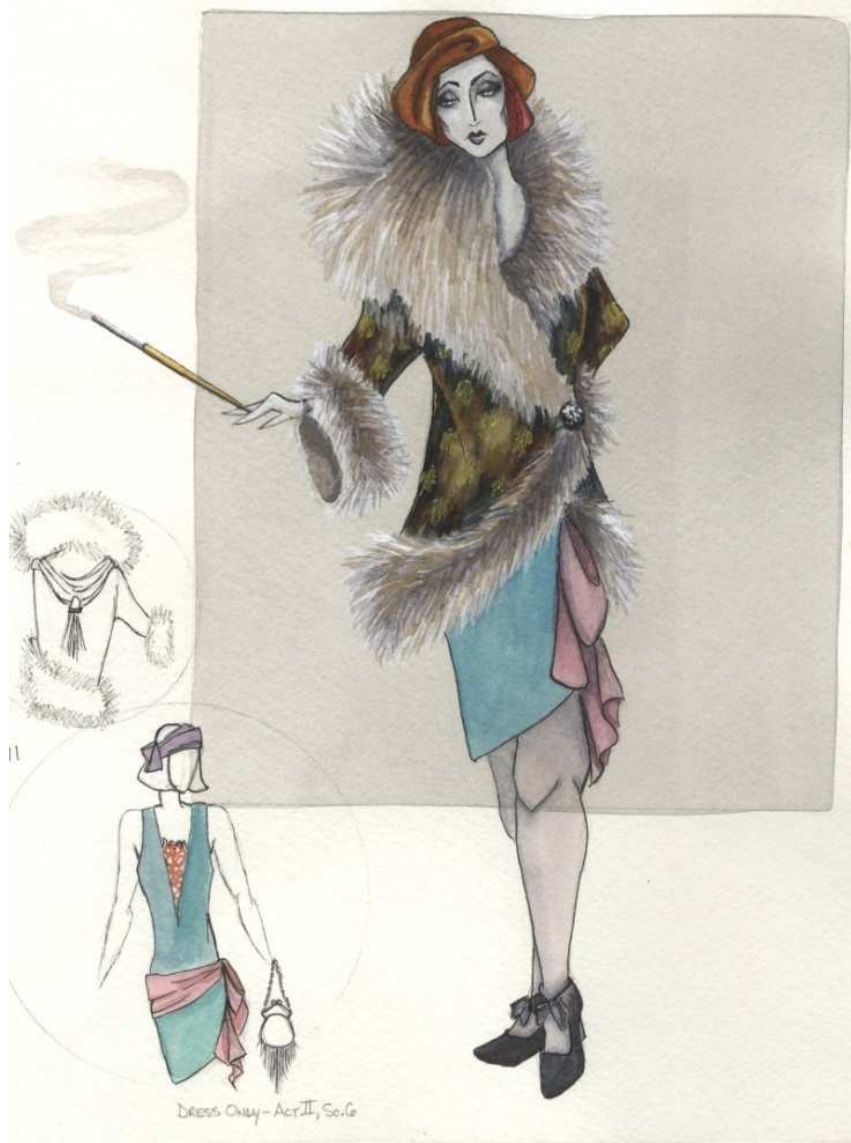

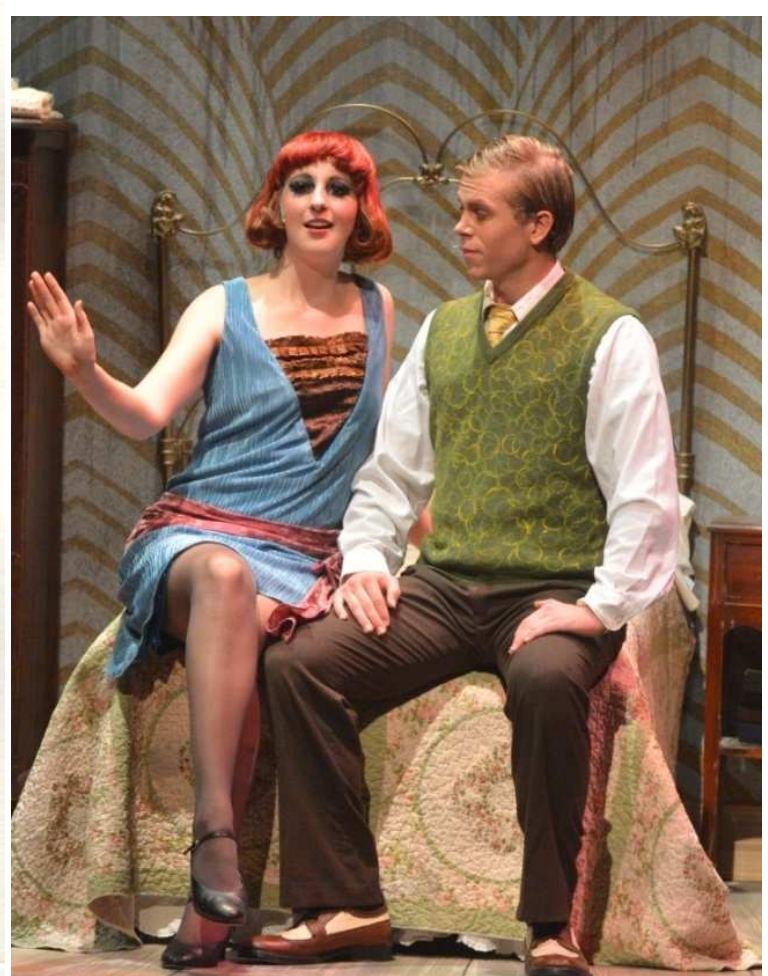




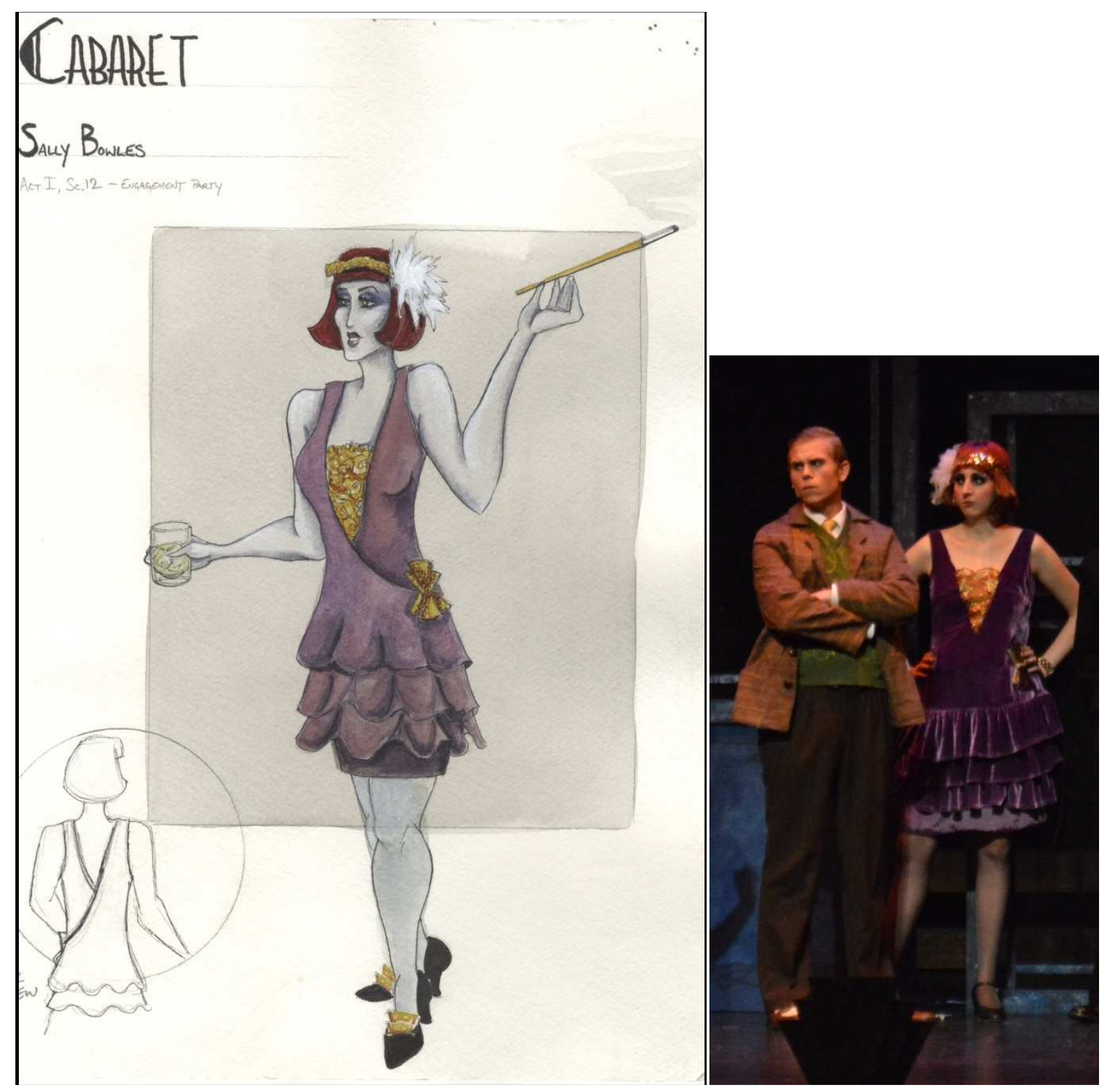


CABAAET

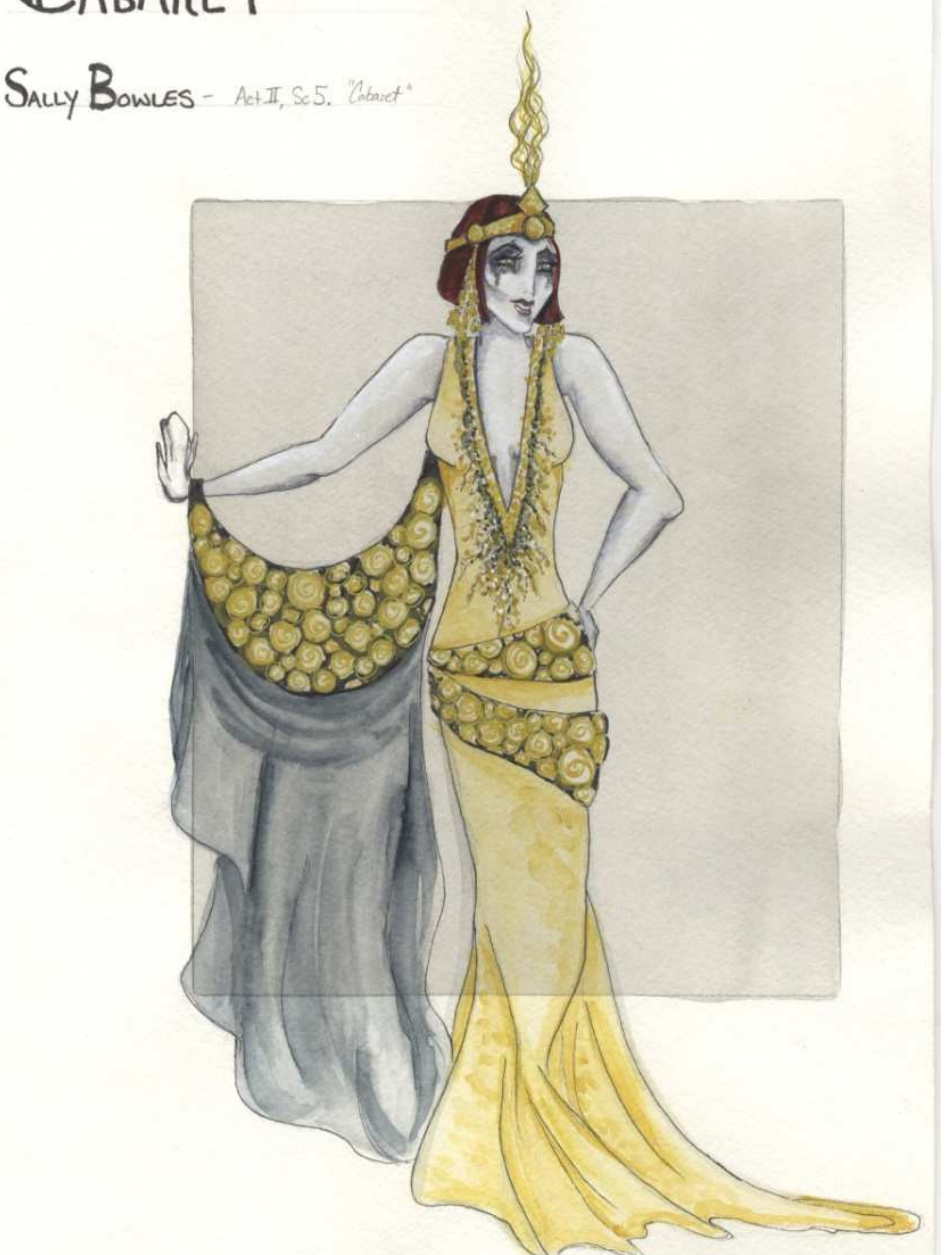

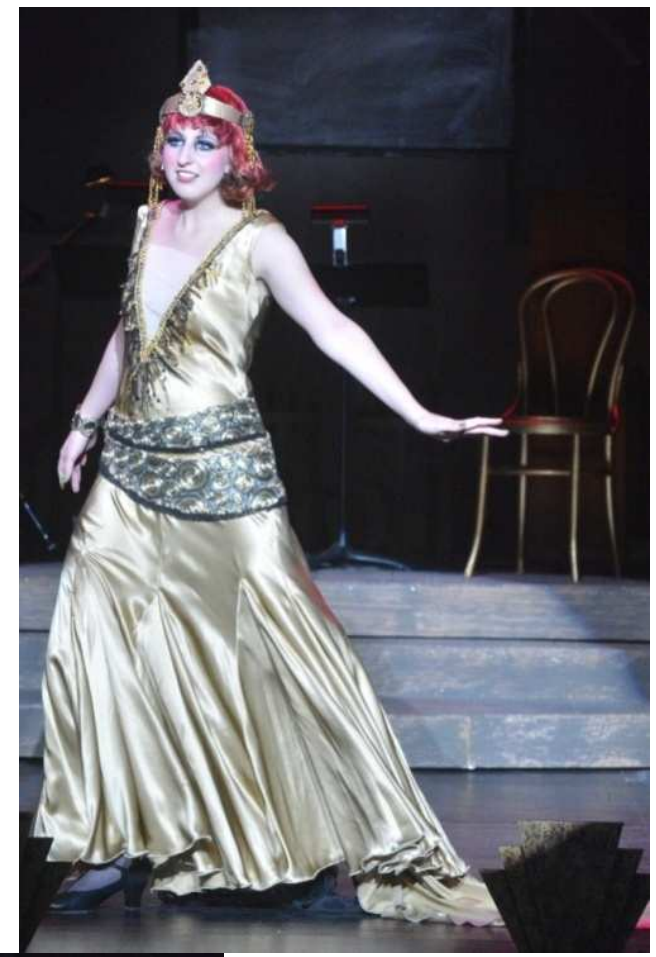

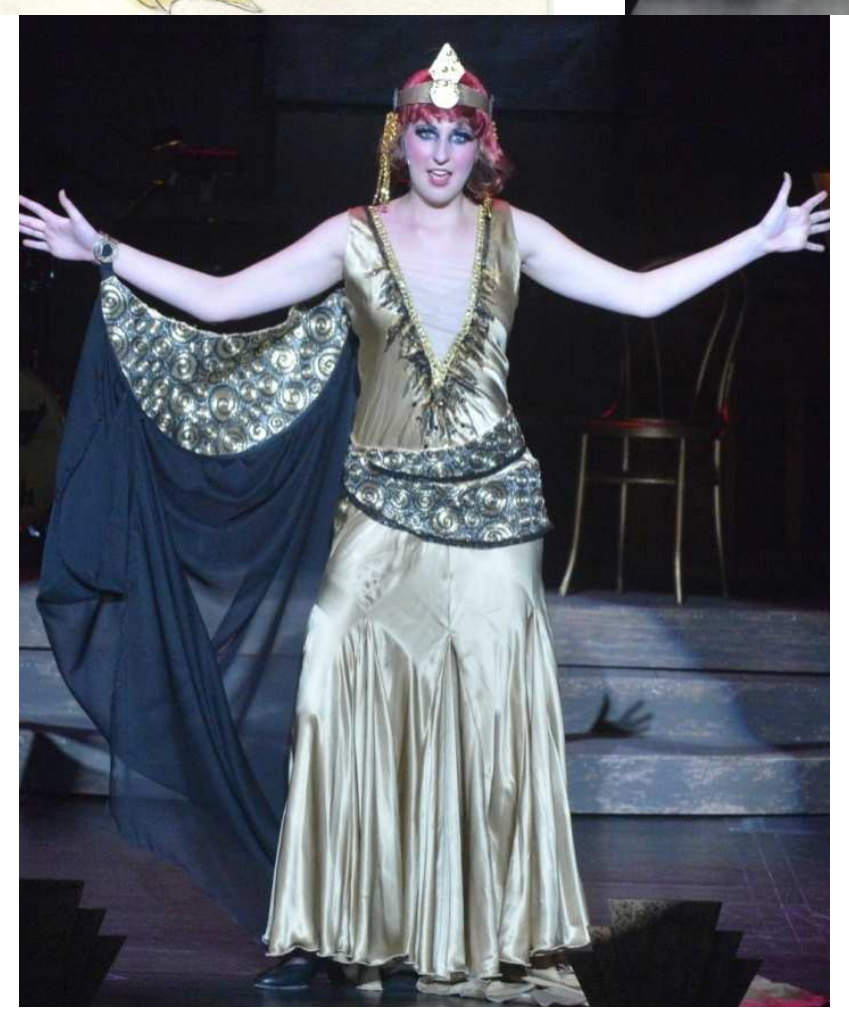


CABARET

Saly Bowles

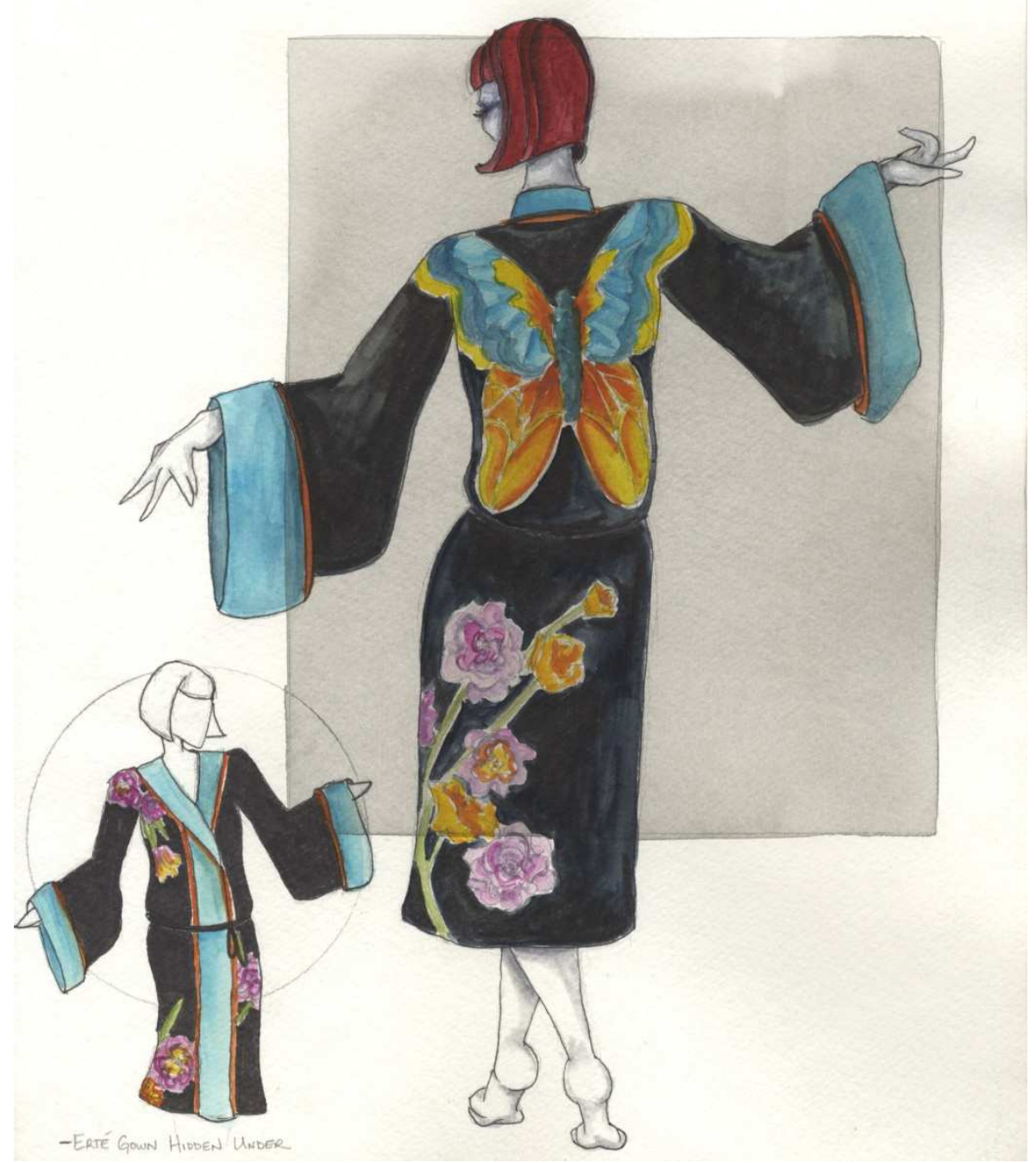




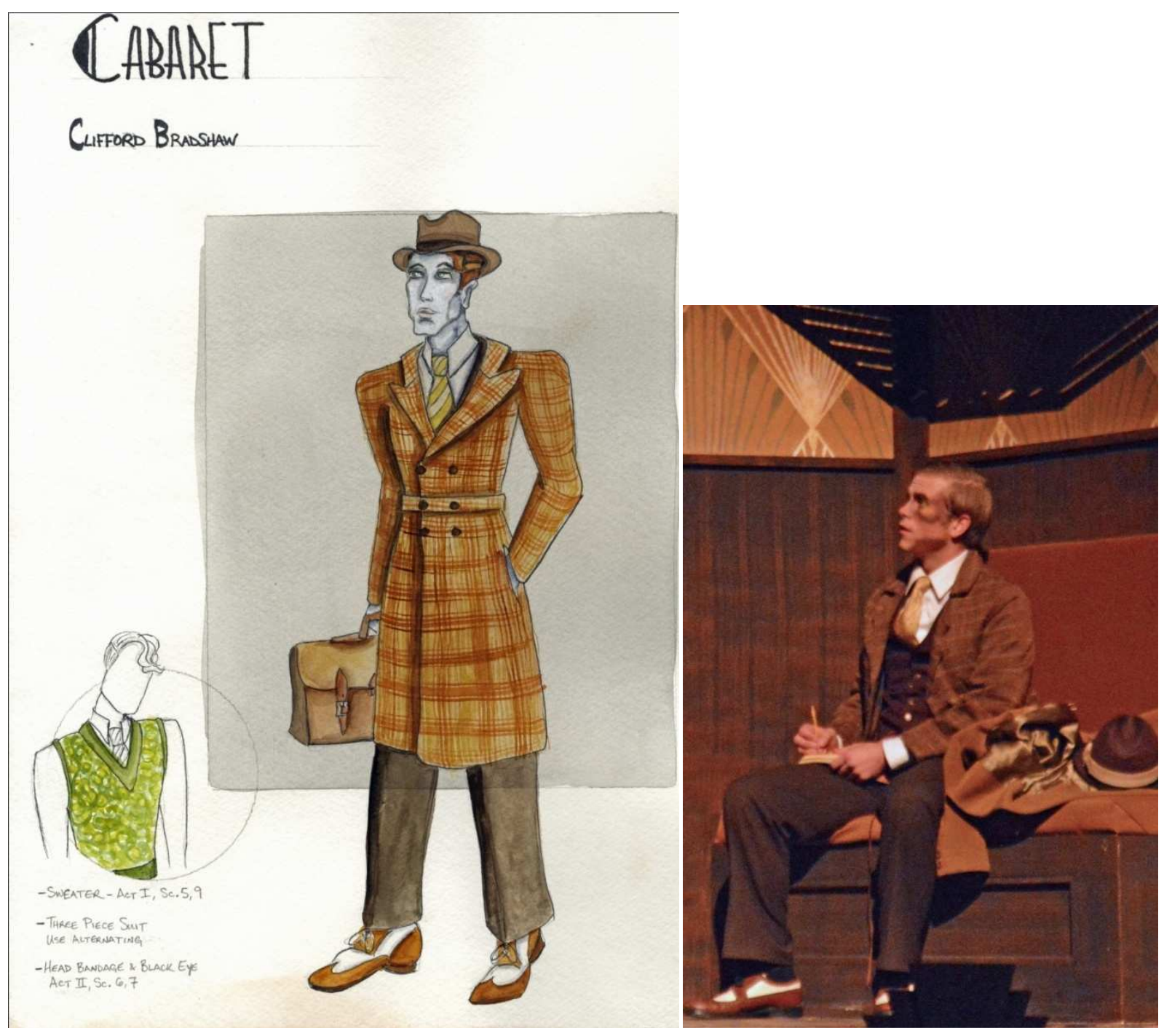


CABARET

ERNST LuONIG
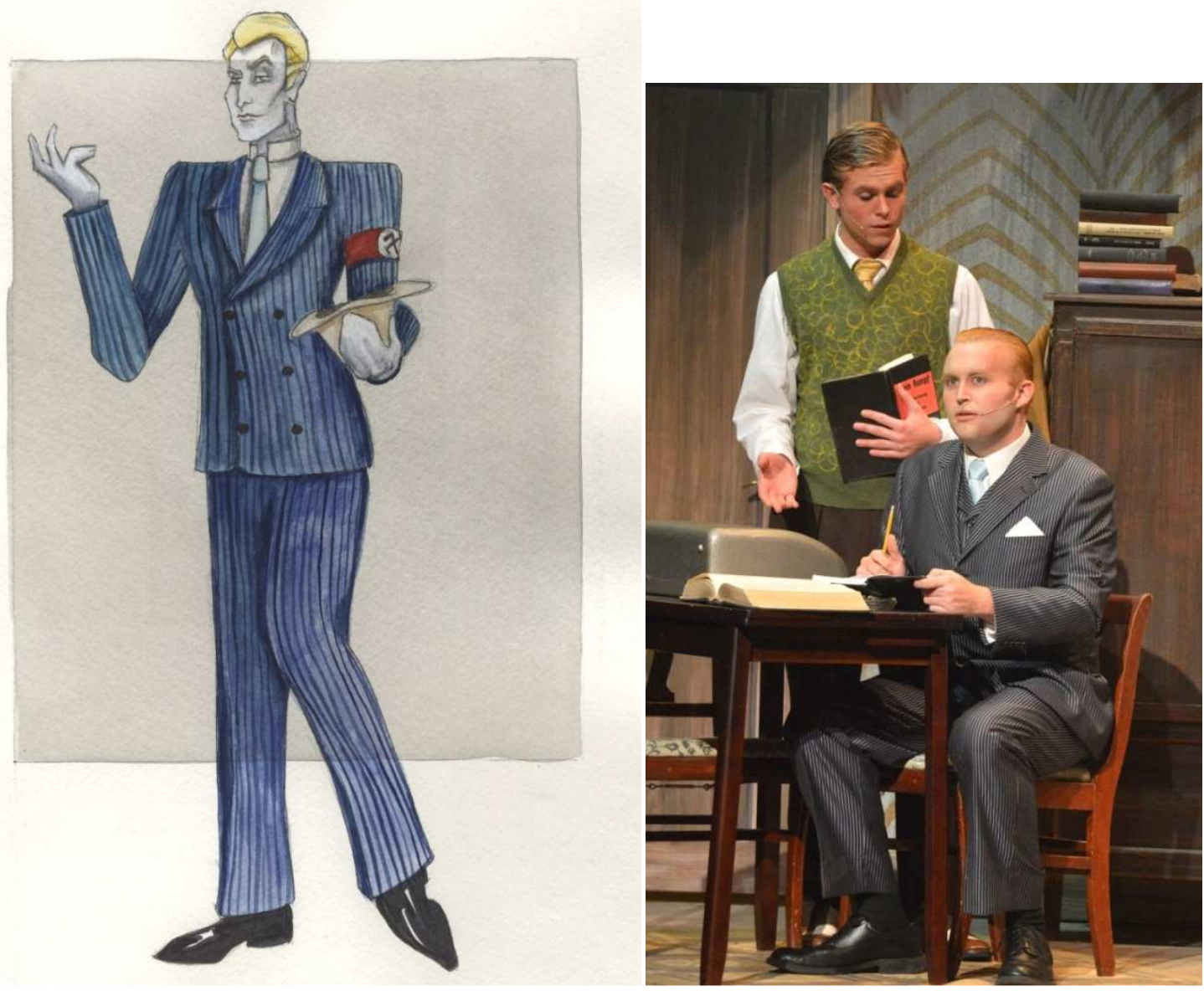
CABARET

Främen Solweder
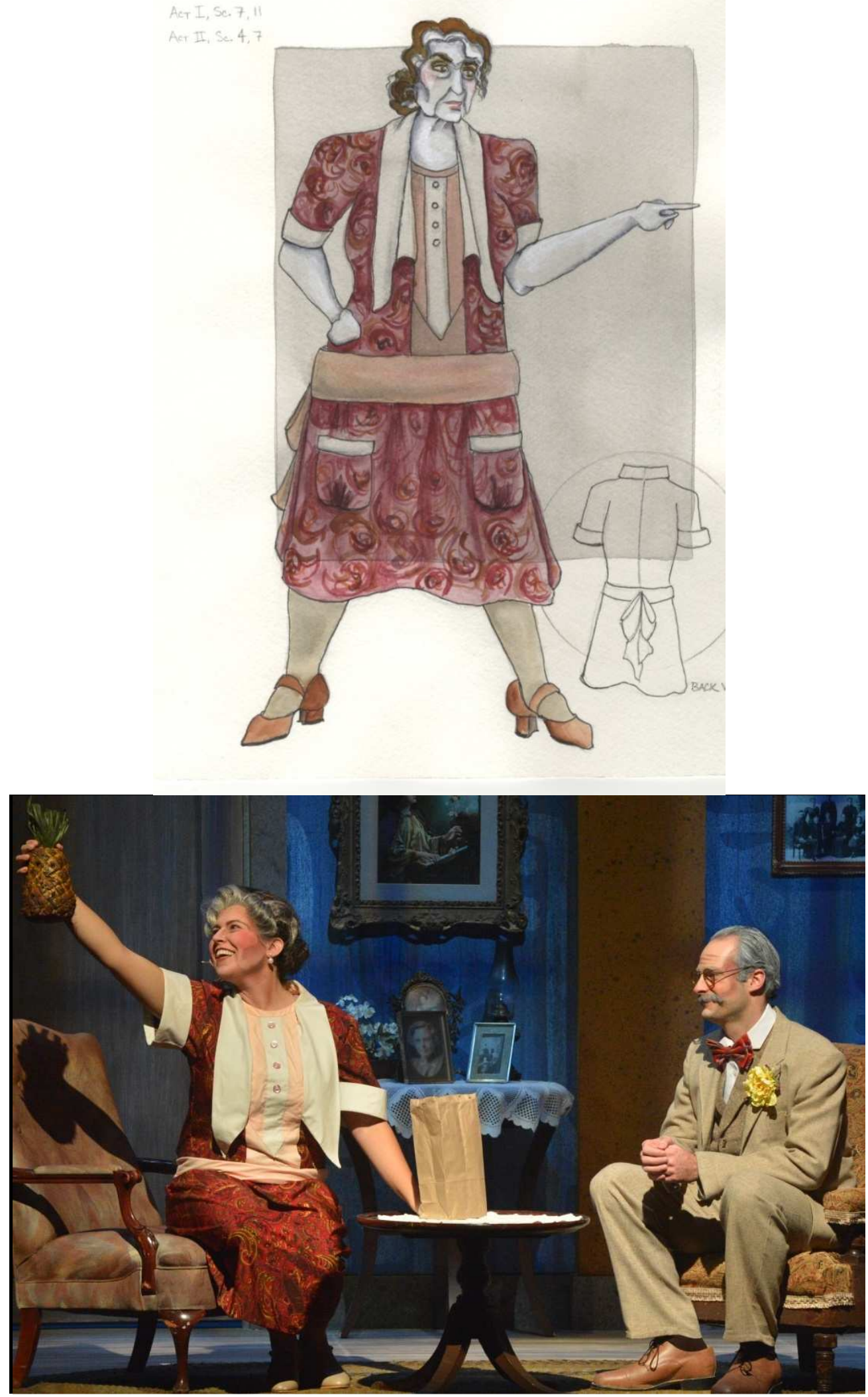
Cabaret

Frailean $S_{\text {chneider }}$
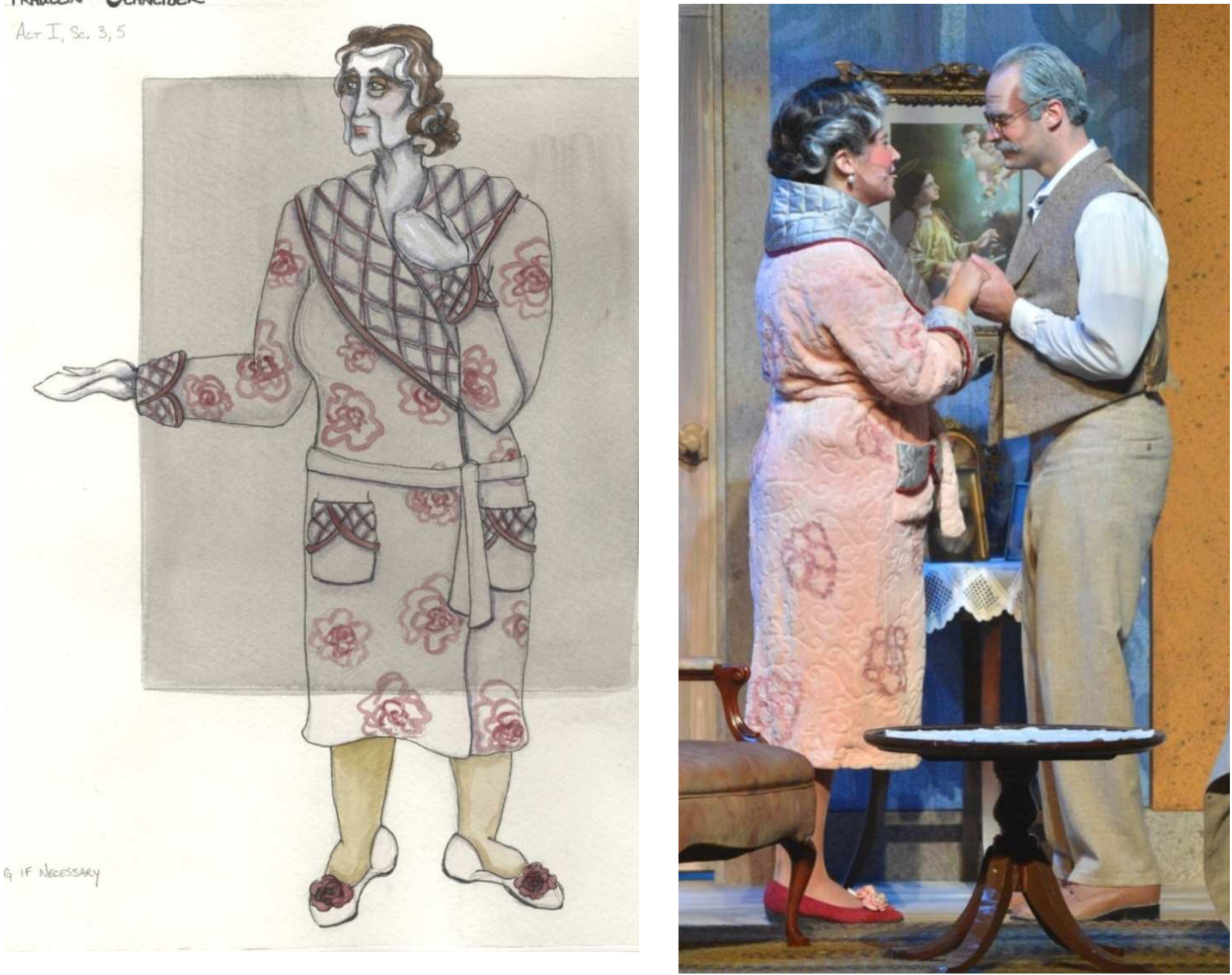
CABARET

Fraimenin Schueider
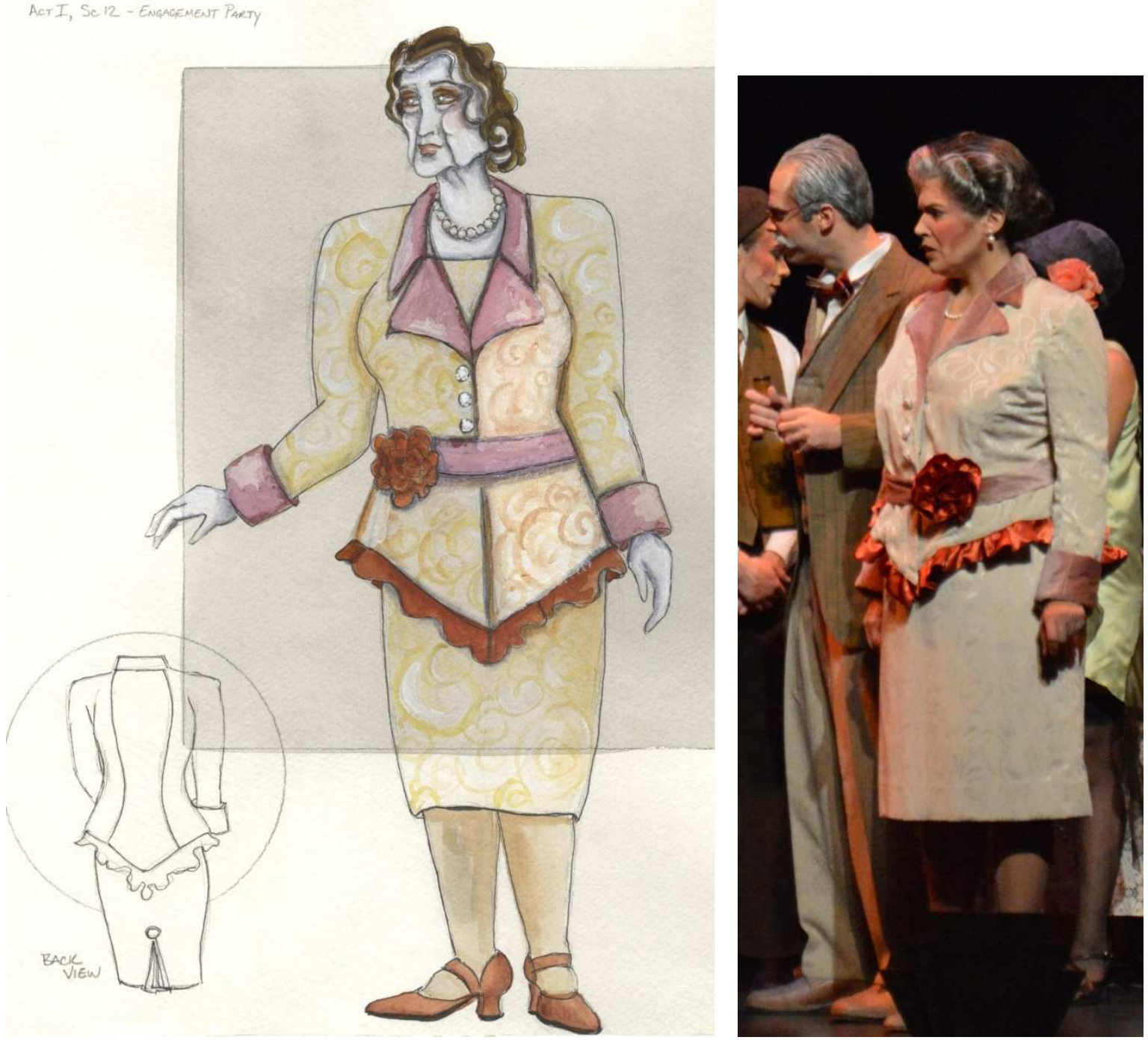
CAbARET

Herr Schultz

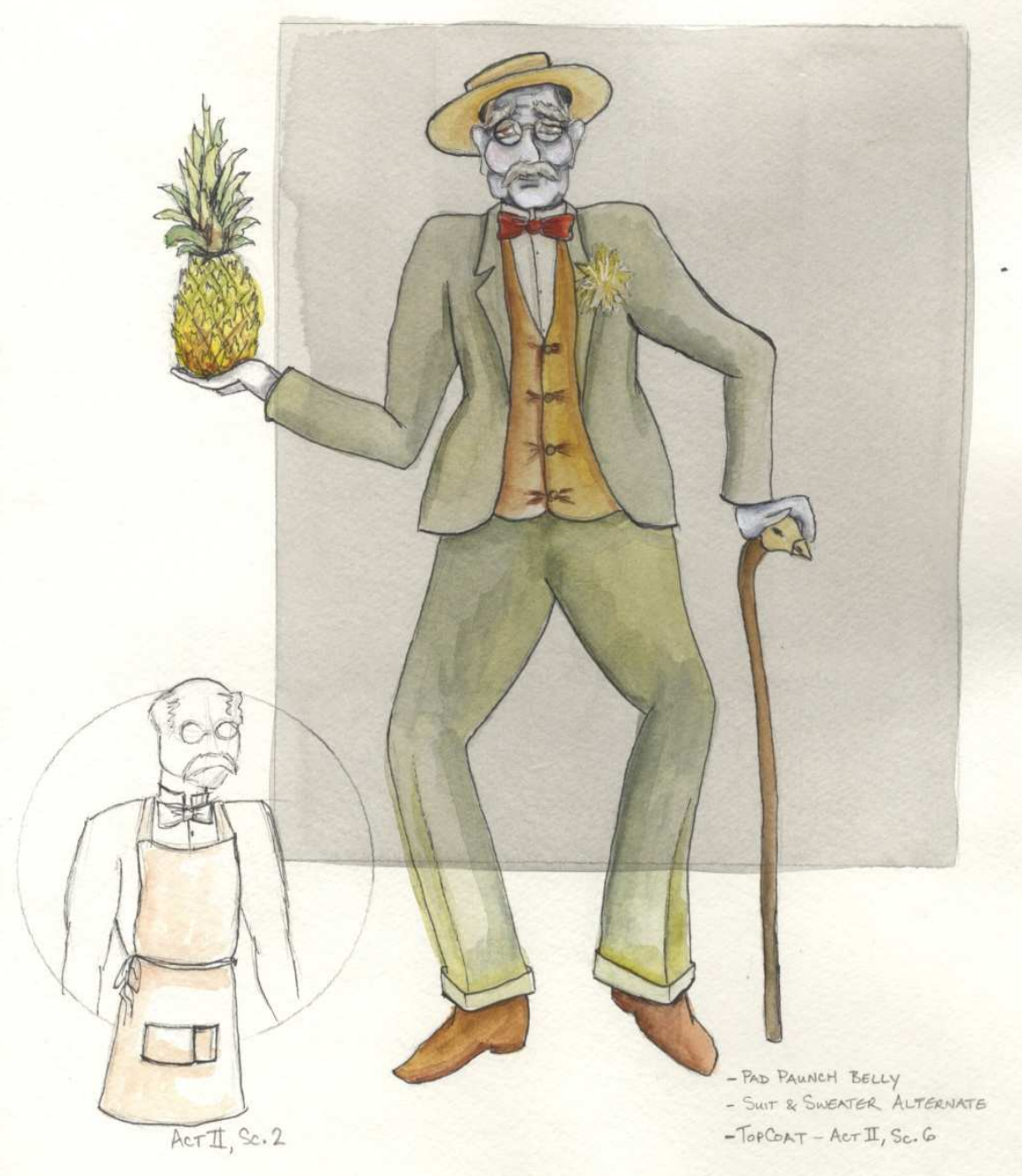




\section{CABARET}

FrAmEIN $K_{\text {DST }}$ \& S SILORS 3
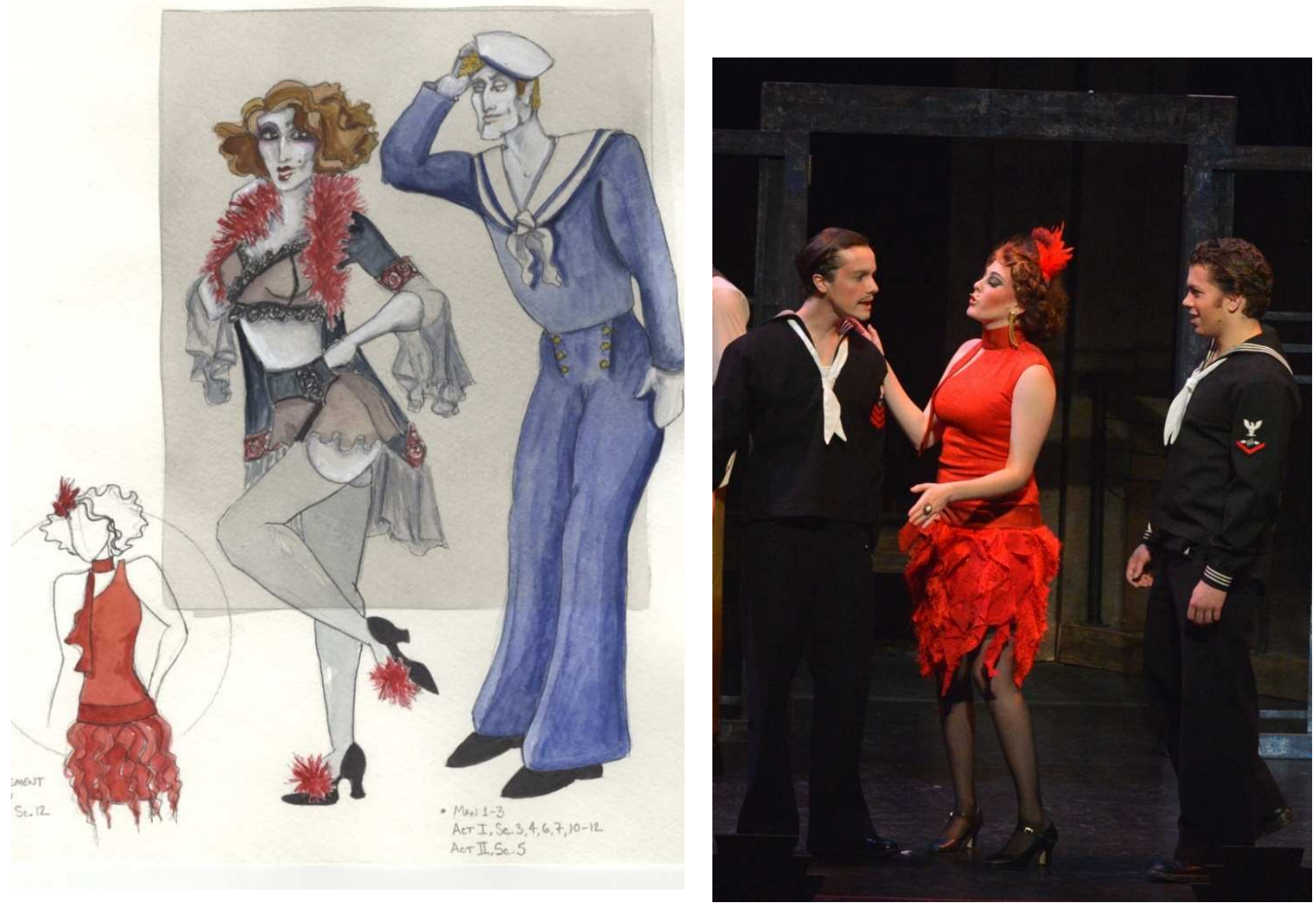
CABAAET

KVT Kat GIRLS
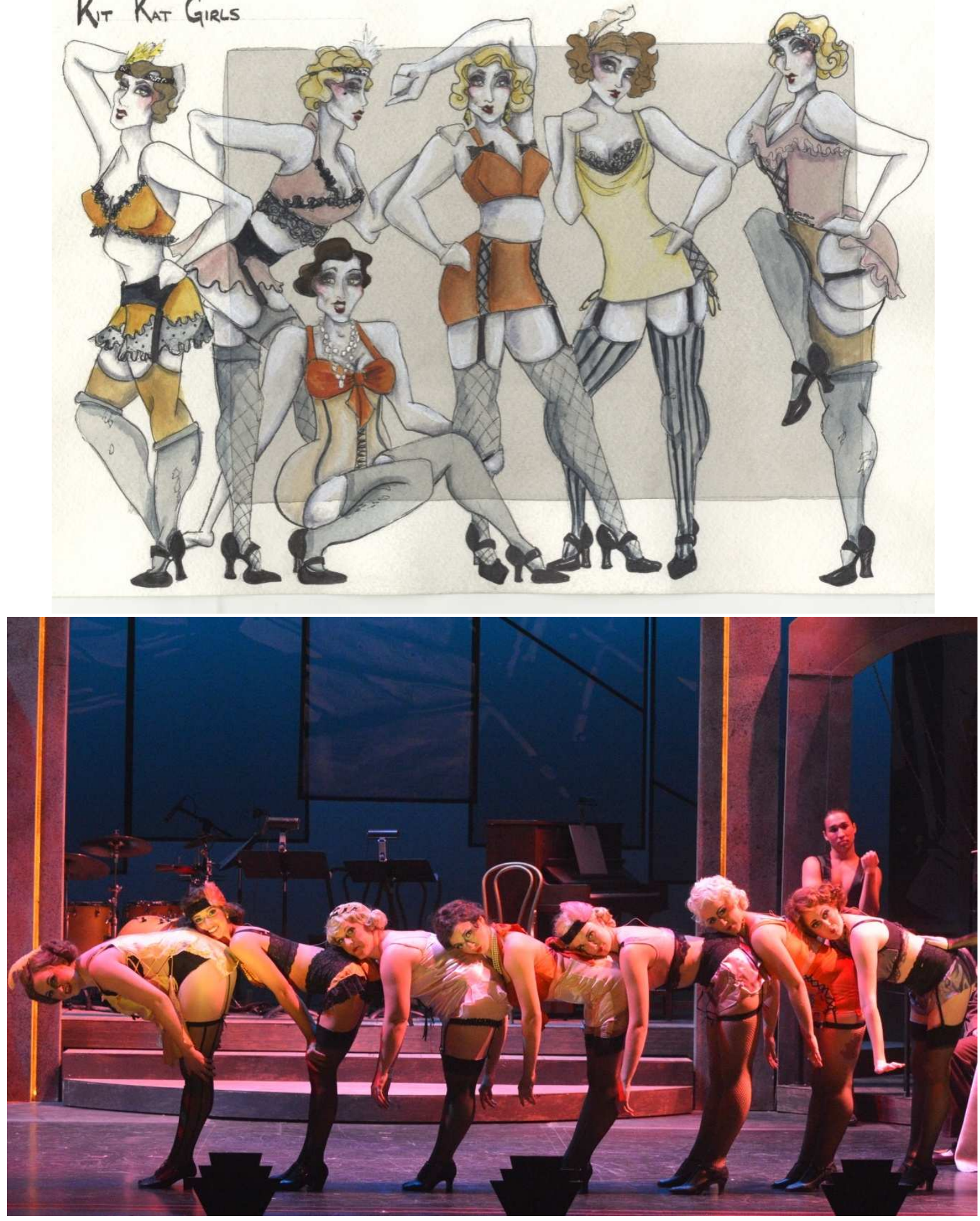
CABARET
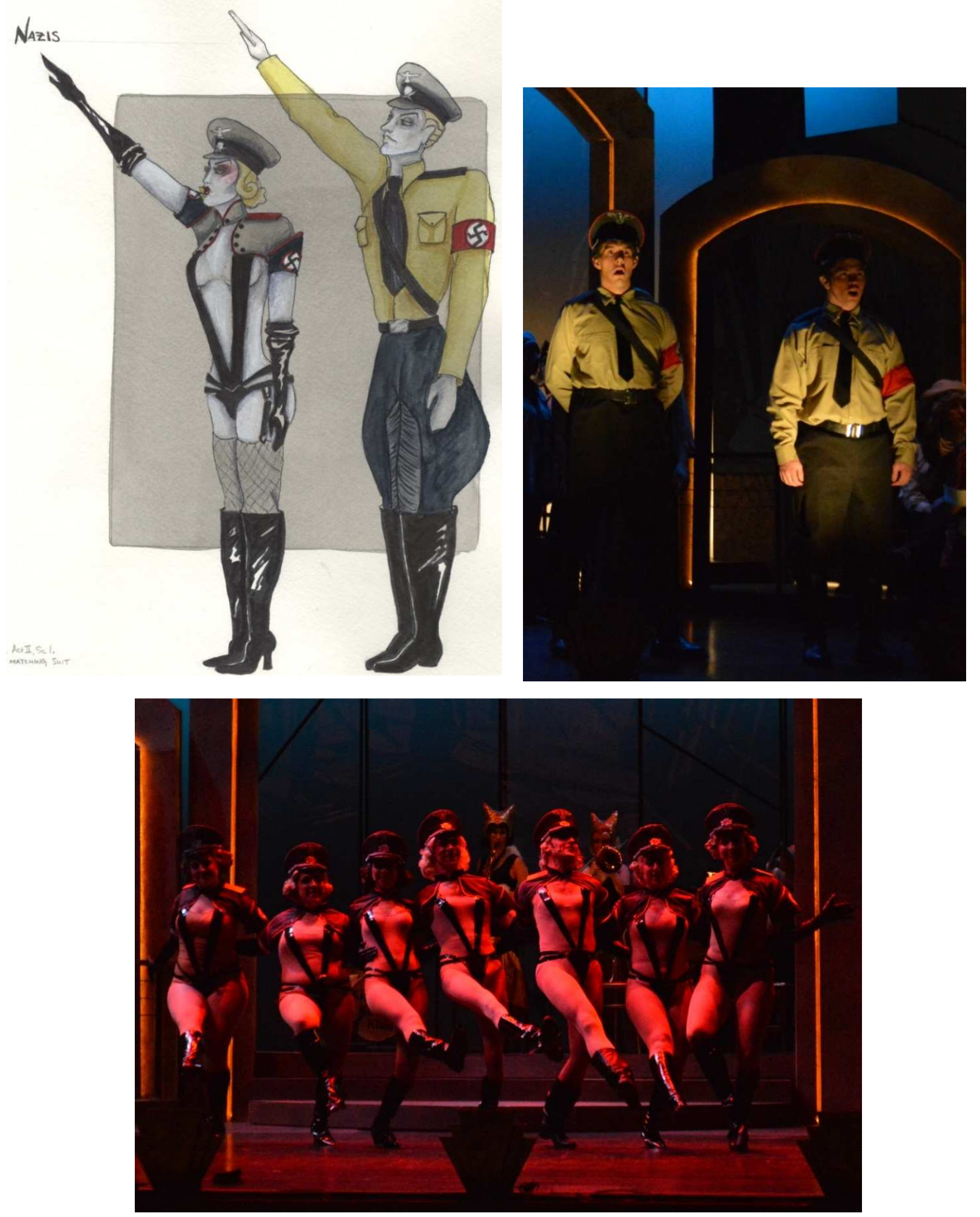
CABARET

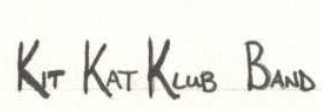
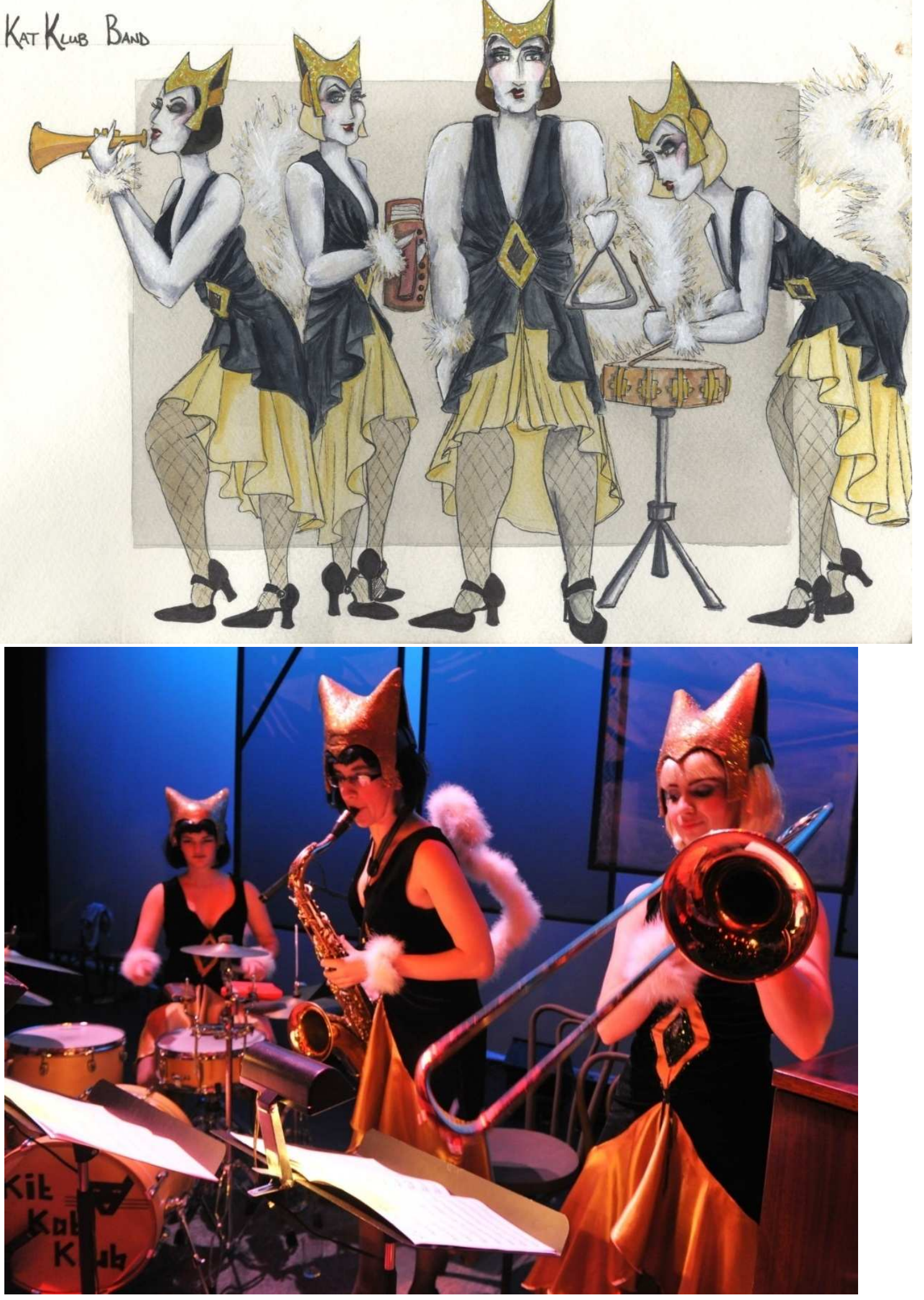